Andrews University

Digital Commons @ Andrews University

1981

\title{
A Functional View of Human Motivation in the Local Seventh-day Adventist Church Based on Theological and Psychological Principles
}

Willmore Duncan Eva

Andrews University

Follow this and additional works at: https://digitalcommons.andrews.edu/dmin

Part of the Practical Theology Commons

\section{Recommended Citation}

Eva, Willmore Duncan, "A Functional View of Human Motivation in the Local Seventh-day Adventist Church Based on Theological and Psychological Principles" (1981). Professional Dissertations DMin. 167.

https://dx.doi.org/10.32597/dmin/167

https://digitalcommons.andrews.edu/dmin/167

This Project Report is brought to you for free and open access by the Graduate Research at Digital Commons @ Andrews University. It has been accepted for inclusion in Professional Dissertations DMin by an authorized administrator of Digital Commons @ Andrews University. For more information, please contact repository@andrews.edu. 
ABSTRACT

A FUNCTIONAL VIEW OF HUMAN MOTIVATION IN THE LOCAL SEVENTH-DAY ADVENTIST CHURCH BASED ON

THEOLOGICAL AND PSYCHOLOGICAL PRINCIPLES

by

Willmore D. Eva

: Chairman: Arnold Kurtz 


\title{
ABSTRACT OF GRADUATE STUDENT RESEARCH \\ Project Dissertation
}

\author{
Andrews University \\ Seventh-day Adventist Theological Seminary
}

\begin{abstract}
Tit7e: A FUNCTIONAL VIEW OF HUMAN MOTIVATION IN THE LOCAL SEVENTHDAY ADVENTIST CHURCH, BASED ON THEOLOGICAL AND PSYCHOLOGICAL PRINCIPLES

Name of researcher: Willmore D. Eva

Name and degree of faculty adviser: Arnold Kurtz, Ph.D.

Date completed: August 1981
\end{abstract}

The hypothesis of the study states that an internalized grasp of the pardoning love of God revealed in Jesus Christ will tend to motivate Christians to a life of Godly activity. At the same time it is recognized that the human being is motivated on the basis of certain natural needs, the need for a sense of belonging, esteem, and self-fulfillment. The study shows how the motive force of God's forgiveness through Christ affects the natural motivational drives of humanity in the local church setting. The possible effect on the local church of intentionally bringing in the word of divine pardon to mingle with the natural, psychospiritual need-drives is central to the study. 
In laying the theological foundation, the plight of humanity and specifically the Christian human is discussed. The Christian person is shown to be in a struggling though motivationally healthy state being in perpetual need of God's pardoning grace. Jesus Christ is seen to be the one who has successfully resolved the human dilemma. He, as God's ideal man, has met savingly with humanity at the level of its most pressing need. As the good news of what God has accomplished in Christ penetrates the receptive mind, faith is engendered and forgivensss is extended, becoming the ongoing motivational principle not only of the individual, but of the communal life of the church as a body.

In the application portion of the study, the theological principles, specifically the motivational force of the pardoning love of Christ, is applied to three dimensions of the local church. At the same time, the natural motivating needs of humanity are also brought to bear on the same three dimensions which are: the way in which the pastor approaches motivation in the church--the ethical dimension; the way the principles of motivation are applied with theological responsibility in worship, preaching and counseling; and finally, how the principles of motivation may be applied in the goalsetting, planning, and general organizational management of the church as an organization. 
Andrews University

Seventh-day Adventist Theological Seminary

A FUNCTIONAL VIEW OF HUMAN MOTIVATION IN THE LOCAL SEVENTH-DAY ADVENTIST CHURCH BASED ON THEOLOGICAL AND PSYCHOLOGICAL PRINCIPLES

\author{
A Project \\ Presented in Partial Fulfillment \\ of the Requirement for the Degree \\ Doctor of Ministry
}

by

Willmore D. Eva

August 1981 

A FUNCTIONAL VIEW OF HUMAN MOTIVATION IN THE LOCAL SEVENTH-DAY ADVENTIST CHURCH BASED ON

THEOLOGICAL AND PSYCHOLOGICAL PRINCIPLES

A project presented

in partial fulfillment of the requirement

for the degree

Doctor of Ministry

by

Willmore D. Eva

APPROVAL BY THE COMMITTEE:

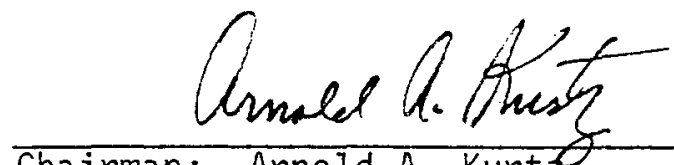

Chairman: Arnold A. Kurt

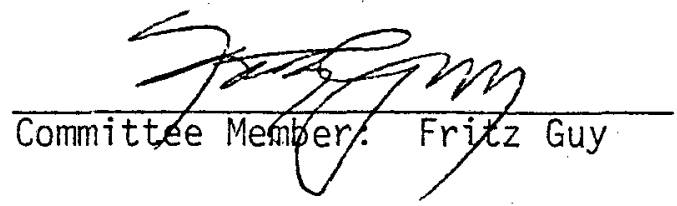

$\frac{7 / 30 / 81}{\text { Date approved }}$
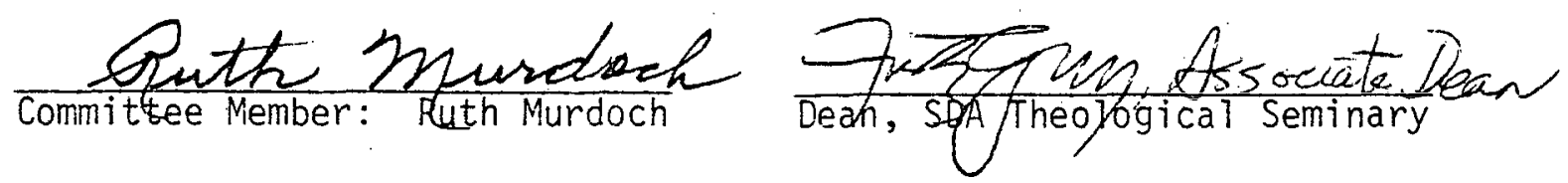
TABLE OF CONTENTS

NOTE

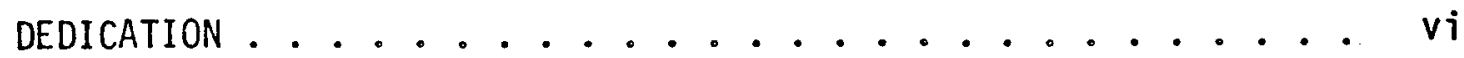

ACKNOWLEDGEMENTS ........................ vi

PART I. A THEOLOGY OF HUMAN SALVATION AND ITS

MOTIVATIONAL. IMPLICATIONS TO CHRISTIAN LIFE

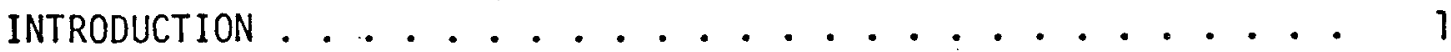

Chapter

I. THE HUMAN PREDICAMENT .................... 12

The Moral Dilemma ............. 12

The Question of Human Sinfulness . . . . . . . 16

The Struggle of the Christian ......... 20

Implications for Human Motivation . . . . . . . 22

II. CHRIST AND THE HUMAN PREDICAMENT . . . . . . . . . 26

The Relation of Christ to Humanity . . . . . . . 26

The Disclosure of God to Humanity . . . . . . . 30

Christ as Coming King ............. 33

Motivational Implications . . . . . . . . 36

III. CHRISTIAN LIFE, THE RESPONSE TO SALVATION . . . . . . 43

The Nature and Exercise of Faith . . . . . . . 4 43

The Holy Spirit and Christian Behavior....... 49

Implications for Human Motivation ....... 56

IV. THE BELIEVING COMMUNITY IN THE WORLD . . . . . . . 61

The Divine Determinacy of the Church ....... 61

The Intrarelatedness of the Church ......... 64

The Church's Relation to the World ......... . 68

Motivational Implications in the Life of the Church . 72

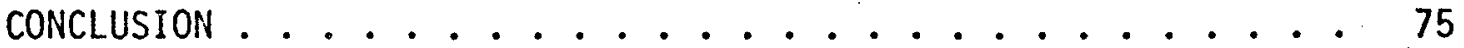


PART II. THE APPLICATION OF A CHRISTIAN VIEW OF HUMAN MOTIVATION TO THREE DIMENSIONS OF

\section{THE LOCAL CHURCH}

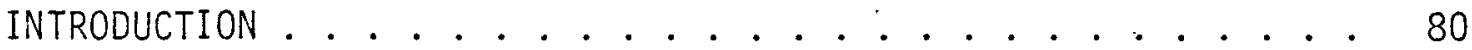

Chapter

I. THE ETHICAL QUESTION IN HUMAN MOTIVATION ....... 82

The Question of Ethics in the Use of

Motivational Stimuli ............ 82

The Question of Manipulation in Motivation . . . . . 84

The Ethical Implications in Natural and

Supernatural Motivation ............ 91

II. MOTIVATION AND THE SPIRITUAL DIMENSION . . . . . . 100

The Spiritual Needs of the Christian Community . . . . . 100

Motivation of the Congregation in Worship and Preaching ............. 107

Motivation in the Care and Nurture of the Congregation ............. 116

III. THE ORGANIZATIONAL DIMENSION ........... 125

Relating Organizational Aspects of Church Life to Human Motivation ........... 125

Meeting Congregational Needs From an Organizational Perspective ......... . 127 Goal-Setting and Planning in Relation to Local Church Motivation .......... 136 The Theological Foundation for Motivation Through Member Participation ... . . . . . . 143

SUMMARY AND CONCLUSION . . . . . . . . . . . . 146

Summary ................. . 146

Conclusion ................ 150

BIBLIOGRAPHY . . . . . . . . . . . . . 155

VITA ................... . 163 


\section{NOTE}

This Doctor of Ministry Project falls under the category described in the Seminary Bulletin as Project II, a paper completed in fulfillment of requirements for an alternate curriculum plan under which the candidate prepares two related papers--a theological position paper addressing some issues or problem that exists in the Seventh-day Adventist church in a theological setting and a professional paper addressing this same issue or problem from the standpoint of ministerial practice. 


\section{DEDICATION}

This project is dedicated with profound gratitude and love to my father whose faithfulness, discipline, understanding, and compassion have gone so far in laying for me the foundational Biblical principles on which this study rests. 
ACKNOWLEDGEMENTS

Sincere thanks is expressed to the Andrews Univeristy Seventh-day Adventist Theological Seminary. A highly stimulating five quarters has provided for me a series of unforgettable positive experiences. This has significantly contributed to my personal adjustment as a minister and to the completion of this project. The generosity of the Potomac Conference of Seventh-day Adventists in allowing me time at the Seminary and providing financial assistance is also greatly appreciated.

Specific and heartfelt thanks is gladly expressed to Dr. Arnold Kurtz, the chairman of my project committee. His personal encouragement, positive attitude in behalf of the student, and his well directed editorial suggestions are greatly appreciated. Dr. Fritz Guy has, under a demanding schedule, spent large portions of time with me and with this project. His careful theological thought and expression, along with his high standards of writing expression, have been a positive challenge and valuable learning experience for me. They have contributed most significantly to this study. The psychological, theological, and spiritual interaction with Dr. Ruth Murdoch evokes deep gratefulness. Her suggestions and inspiration have been most helpfut.

The patience, willing help, and sacrifice of my wife, Claire, herself working on a demanding M.A. program at the time this project 
was written, is appreciated beyond words. The sacrifices of my children Amy and Jonathan during the time of study are appreciated with much love. The overall inspiration and the practical unconditional "positive regard" shown me throughout my life by my mother, Gloria Eva, have been of crucial significance in opening to me the value of the central theme of this study.

I also appreciate the editorial work of Cheryl Jetter. The friendship, patience, and skillful typing ability of Gail Valentine have been very helpful.

To the One who is always faithful, full of love, and the desire to save and help, goes not only thanks but humble praise and worship. 


\section{PART I}

A THEOLOGY OF HUMAN SALVATION AND

ITS MOTIVATIONAL IMPLICATIONS TO CHRISTIAN LIFE 


\section{INTRODUCTION}

The study and implementation of the principles of human motivation have not received the kind of attention in the church that they have in other sectors of contemporary society such as the field of business. ${ }^{1}$ This is understandable, for aside from the fact that there is no overt treatment of this subject in scripture, there is among some Christians an antipathy to the use of psychological principles generally. Added to this is a certain ambivalence with regard to the adaptability of many of the principles of secular business management to the church. ${ }^{2}$ The question particularly comes, then, Can one safely intergrate the discoveries of social psychology in the area of human motivation and put them to use within the twentieth century Christian church?

There is another question which at times occupies the Christian community: What was it that motivated the first-century Christian community to the unique explosion of growth both in holy living and potent witness? The question becomes particularly intriguing

ISee Judd Morris, The Art of Motivating (Boston: Industrial Education Institute, 1968). This is an example of numerous books in this field.

${ }^{2}$ See Richard G. Hutchison, Jr., Wheel Within the wheel: Confronting the Management Crisis of the PJuralistic Church (AtTanta: John Knox Press, 1979), pp. 67-87. 
when one realizes that though there is much exhortation in the New Testament to holy living, aside from the "great commission" (Matt 28: 19, 20; Acts 1:7-9), there is very little overt exhortation to early Christians to share their faith. Yet their faith was most certainly shared. What was the motivational force behind this? What does this say to the contemporary church? In the face of a 11 the creative and persuasive exhortations to "witness" that may be heard as almost central to Seventh-day Adventist communal life for example, why are the results in the church less satisfying than any committed Seventhday Adventist would like? Why aren't these exhortations more productive of the kind of activity they attempt to bring about?

This study endeavors to feel the weight of all of the questions of the preceding paragraphs. In dealing with the adaptation in the church of the insights of the behavioral sciences in the area of motivation, an attempt will be made to look carefully at such insights in the light of that which is central to the New Testament and its community: the Christian Gospel.'

A] though much of the motivational energy of the first century church may be lacking today, the degree of sophistication in contemporary churches does not call for a more subtle form of manipulative motivation. It seems rather to call for an open, mature, yet transparent approach, centered in the Gospel and its implications, where trust and equality exist and where members of the community of faith are basically conscious of what it is that moves

and 5 .

IFor a definition of the New Testament gosper, see pp. 4 
them to Godly activity. ${ }^{1}$ The desire for this kind of approach will, it is hoped, control any unwarranted excursions into unacceptable adaptions of "secular" principles, while at the same time capitalizing on the helpful contributions of behavioral and managerial science. It is anticipated that these valid applications will show themselves especially in Part II of the study.

The study embarks with the hypothesis that an internalized grasp of the pardoning love of God in Christ will tend to move Christians not only to action, but to Godly activity; that it is ultimately the death and the merciful grace of God in Christ which motivates genuine Christian behavior. The blunting of the perception of this principle in our day may make it appear less motivationally effective than in fact it was in the first century Christian community. Yet it is here hypothesized that this principle, fundamental to the New Testament, is foundational also to the matter of contemporary Christian motivation.

It may be because of this blunting that there is among pastors the tendency to manipulate parishioners into specific forms of Christian activity through rather questionable motivational means, such as guilt, fear of Divine punishment, disesteem, or rejection. ${ }^{2}$

The term "Godly activity" as used in this study includes the full range of positive Christian behaviors. No attempt is made to divide such activity into categories. Christian witness is included here along with all of the positive activities of the Christian person and the avoidance of those activities foreign to God's will.

${ }^{2}$ See S. Bruce Narramore, "Guilt: Christian Motivation or Neurotic Masochism?" Journal of Psychology and Theology (Summer, 1974): 182, 183. 
This study will offer some alternative motivational appeals while it still calls for pastors to challenge the church to high standards of Godliness.

Besides the use of manipulative motivational strategies, it sometimes becomes evident in the church that little intentional thought has been devoted to the matter of motivation. It is hoped that this study will agitate a more carefully thought out, less hit-and-miss approach to moving people to change within the church.

The foundational question of the study is, What causes the Christian to live and act according to the principles of Christ? Although this question will not appear overtly, throughout the study it will underlie all conclusions. The more practical implications of this question will be dealt with in the second part of this study. The two aspects most relevant in the study will be the only two which will be defined at this point. They are the gospel and human motivation. The passage of scripture that comes closest to a definition of the New Testament Gospel is perhaps 1 Cor 15:1-8. The first characteristic of this passage is that it refers to a closely related series of concrete historical events: (a) that "Christ died for our sins" as scripture said he would; (a) that "He was buried;" (c) that He was resurrected on the third day, also according to scripture; and (d) that He appeared to many including Paul. Its second characteristic is that as this historical happening is preached and received, and as people "stand" in it (vs. 1) and hold fast to it, believing it (vs. 2), they are saved.

It is clear from the New Testament that this saving includes 
a radical behavior change. This may be seen in the ethical teaching of the New Testament as a whole and more especially in the very structure of the Pauline espistles. In most of these epistles, Paul proclaims the good news of Christ's work for humanity and then exhorts to ethical or moral behavior. It is crucial to the understanding of this study that the integral connection between the behavioral change and the gospel be made. It is equally critical that these ethical or moral changes not be seen as a part of the gospel itself, lest the potency of the gospel to alter human thought and behavior be diluted by bringing in the uncertainties and imperfections of human activity. The definition of the gospel (good news) centers in the historical action of God in Christ for humanity. Its effect is moral and ethical change. Its inevitable corollary is a life highly motivated by the atoning, interceeding work of Christ through the Holy Spirit.

The only other definition discussed at this point will be that of motivation. A simple but accurate definition of motivation is not easily formulated. But we may begin with the fact that motivation has to do with

such diverse states as desires, wishes, plans, goals, intents, impulses and purposes. Some of these states imply a deliberate and calculated process involving reason, whereas others convey a flavor of spontaneity. . . . In general, when we speak of motives we are referring to the causes or reasons that underly a given behavior.

It is useful to distinguish what the term "motive" means in experimental psychology from what it means in a more philosophical

'John Jung, Understanding Human Motivation (New York: Macmillan Publishing (o., 1978), p. 4. 
psychology. ${ }^{1}$ In the former, a more functional, operative description is given having to do with inner need-reduction drives. It has to do with outer stimuli such as curiosity, manipulation, defense, or learned responses. Such drives tend to push a human into action. Although this type of motivation is relevant to this study, it will not be the main focus. For the more philosophical psychologist, motivation has to do more with elements that draw than with those that drive. It refers to "a good and value for-the-sake-of-which the agent acts." 2 In this study this "good and value" is the work of Jesus Christ forged out in behalf of humanity especially upon the anvil of Golgotha. The approach here involves calling in this "good and value" that it may mingle with the inner need reduction drives of man, creating a wholistic approach to the question of motivation. It is hoped that the validity and practicality of this approach will become evident.

It is clear that the average person, and just as significantly the average pastor, does not draw subtle distinctions between one sort of motivation and another; but that daily life, i.e., the daily religious life, finds its activity emanating from a multidimensional configuration of motives and submotives.

The matter of human needs must underlie much of what is said about a definition of motivation. Human need is basic to motivation

${ }^{1}$ See Robert J. Austgen, Natural Motivation in the Pauline Epistles (Notre Dame: University of Notre Dame, Press, 1966), p. 3. 2 Ibid., p. 3. 
and is quite universally seen as such.' The extent to which primary needs (shelter, food, safety, a sense of belonging, esteem, and selfactualization) are met or unmet determines the extent to which a person is motivated. ${ }^{2}$ These needs in turn determine behavior. Abraham Maslow's view of human motivation sees within the human being a set of overall needs which motivate human behavior and shape human thought. Until these basic necessities are provided for, in a reliable, ongoing manner, a person's life will be dominated by them. Such a domination disallows any deep interest in other potentially emerging needs or motivations. But when the primary needs (i.e. physiological and safety needs) of a person are dependably met then a new and "higher" set of requirements (need for belonging, esteem, and self actualization), takes over the motivational center of a person's life. In this way, Maslow viewed human beings as developing through a hierarchical need structure, from the basic survival necessities to the "higher" more "spiritual" needs. 3

Beyond this a crucial question emerges: What happens when these needs of a person are largely met? What then becomes the motive force? Early in his study, Motivation and Personality, Maslow recognizes this apparently contradictory aspect of human motivation:

'The contributions of radical behaviorists such as $B$. F. Skinner have been purposely ommitted in the overall discussion of this study. Their less phenomenological approach does not lend itself to consistency with the basic thrust of this study's perspectives.

${ }^{2}$ See Abraham H. Maslow, Motivation and Personality (New York: Harper and Row Publishers, 1954), pp. 35-38.

3Ibid., pp. 35-47. The term "higher" is Maslow's. The term "spiritual" is not. 
What this means is that, e.g., a basically satisfied person no longer has the needs for esteem, love, safety, etc. . . If we are interested in what actually motivates us, and not in what has, will, or might motivate us, then a satisfied need is not a motivator. It must be considered for all practical purposes simply not to exist, to have disappeared. This point should be emphasized because it has been either overlooked or contradicted in every theory of motivation I know. . .

Stating Maslow's thought in the terms of this paper's discussion may not do justice to his overall structure, but his thought does cast light on what is critical to this study. Using a biblical example we might say that when God led Israel out of Egypt, he satisfied Israel's basic needs for survival, security, a sense of belonging, esteem, and self actualization. God's statement through Moses was, "Let my people go, so that they may hold a festival to me in the desert" (Exod $5: 1$ ). God's liberating act met the needs of Israel, but it opened up to them a new existence and thus a new spectrum of motivational forces. It exposed for them the real reason for their existence: not that of a preoccupation with their own needs and drives (as valid as these must always be seen to be) but a preoccupation with the worship of Another, a preoccupation with the need to be loved, yes, but further than that, the need to love, worship, and serve. As long as the Israelities remained on the "Egyptian plain" of chronically unmet needs, they were not entirely free to worship or to serve because they found themselves engrossed with the satisfaction of more primal needs. When these needs were met Israel became vulnerable to a new plane of motivation which was less driving in its nature.

\footnotetext{
I Ibid., p. 57.
} 
This matter of need reduction becomes crucial to a definition of human motivation for this study. It is important that the basic psychospiritual needs of people be met by that which was divinely designed to do so--the good news of salvation through the rightness of Another. As this is done, the fundamental roadblock to a more effectively motivated life will be removed while the way for holiness and service comes into being. It must be noted just as significantly, however, that Maslow's man with-all-needs-met is a man who to all intents and purposes does not exist. ${ }^{1}$ The higher, less physiological needs such as self actualization are never finally and irrevocably met. Beside this, even the physiological needs, though they may be satisfied, are never guaranteed. The same tension--between needs being met while at the same time they have not been fully met--exists in the existential Christian context. The Christian is one who because of Christ, rests in a work that has destroyed his slavery to his primal psychospiritual needs. His hands are freed from the work of contributing to his own safekeeping. He is free to deal with God's will and service more directly. At the same time, though free, he is constantly aware of needs that move him strongly toward a constant calling after God, for protection and supply.

A definition of motivation which takes into account the foregoing discussion is: that which a person has consciously or unconsciously in mind when he acts. It is the need or desire

${ }^{1}$ Maslow does allow in his theory that the highest need in the hierarchy, self fulfillment, is never fully met, thus leaving room for certain motivational stimuli to continue their dynamic influence. 
which influences a person's will thus moving him to action. It involves incentives and goals which are continually active and ever in the process of emerging.

The question may well be raised at this point, Exactly how is Maslow's hierarchy of needs used in this study? Can it indeed be mixed with a biblical or spiritual approach in the church? To this let it first be said that Maslow's approach as a whole will not be employed. Maslow is instead adapted in a highly selective way. The idea of the human being possessing certain physiological and psychological needs will be dealt with. It is also accepted that these needs are largely hierarchical in nature (until the more foundational needs are satisfied a person tends not to deal with or be motivated by other less basic needs).

It is also assumed that the spiritual needs of the human soul reflect the emotional needs of the human psyche. In other words, the three "upper" (psychological) needs in Maslow's hierarchy'-a sense of love and belonging, esteem, and self actualization--may be seen in spiritual terms as the need for favor (esteem) in God's eyes and before fellow humans, and the need for completeness (self actualization) before God and within oneself. This adaptive, "spiritual" use of Maslow is particularly helpful in the theological exposition, and it will not be ignored in the application portion of the study.

These three areas of human need (the need for belonging,

'See Maslow, pp. 43-47. 
esteem, and self actualization) will be used heuristically in the study. That is, these three psychospiritual desires in the human being will determine what will be discussed in the study and how the study will be approached. In this way, Maslow's approach will be adapted to the study. 1

The theological exposition which follows is organized around certain classical categories of theology: humanity, Christ, faith, and church. The final section of these chapters is a discussion of the implications of the chapter's content for motivation in Christian life. Each of these themes will be discussed in soteriological terms, while the principle of human motivation is kept in mind. The exposition moves from the dilemma of Humanity, to Christ's resolution of the dilemma, to Faith as the means by which humanity perceives and grasps Christ's work, ending with the implications of this work to the Church as a body.

Jesus, thy Blood and Righteousness

My beauty are, my glorious dress;

'Midst flaming worlds, in these arrayed, With joy shall I lift up my head.

TFor a related discussion and a Christian approach to Maslow, see Keith Miller, The Becomers (Waco, Texas: Word Books, 1973), pp. 89-99.

${ }^{2}$ From a hymn quoted by Helmut Thielicke, The Trouble with the Church (New York: Harper and Row, 1965), p. 88. 


\section{CHAPTER I}

\section{THE HUMAN PREDICAMENT}

\section{The Moral Dilemma}

The moral predicament of humanity has been described by

Helmut Thielicke:

I ought but I cannot. I cannot because I am what I am. . . . Man can alter himself only in his acts, not in his nature. The "I am" has determinative force for the "I will." This is why works cannot save. The "I will" cannot change the "I am." Good works do not make a good man, but a good man does good works, as Luther puts it. Behind his works, man is still the same man. Over this he has no control. Hence he has still to despair of God's total claim or to reject himself.'

This dilemma, says Thielicke, has its genesis in the presentation of a law that has "universal validity" in that it calls out the highest worth that the human mind can think of. ${ }^{2}$ Without discussing (as Thielicke does) many of the expanding implications of this viewpoint as it relates to humanity generally, we will assume that this "universal validity" is God's moral decalogue. It will further be assumed that this law, with its scriptural ramifications is accepted by the Christian as determinative for the thought and behavior structures of life.

IHelmut Thielicke, The Evangelical Faith (Grand Rapids: William B. Eerdmans, 1974), p. 142.

2Ibid., p. 141 . 
It is against the backdrop of this law that the Christian finds human life projected. This projection reveals that though a person may know what the law says, and though the wish to obey it may be present, the "I will" in itself cannot change the "I am." This is, as far as the Christian is concerned, the very plight that Paul expresses in Rom 7:74-24. Here is described the dilemma of persons who, in the face of the law of God know that in spite of themselves they continually come short of God's standard, his glory (Rom 3:23). The "Man" of Rom 7 accepts the just claims of the law (Rom 7:16) but. finds that though he wants to obey it (vss. 15, 16, 19, 21) he is constantly coming up against a "law" within himself that keeps him. from doing so (vss. 21-23). At this point the cry of confessional despair is made, "0 wretched man that I am! Who shall deliver me from the body of this death?" This is not merely a cry of guilt, but it is a cry of repentance in the face of a conscious inability to fulfill the universal imperative, God's all-inclusive claim upon human beings through His law. The radical claim of obedience that is made by Jesus on the conscience of humanity--for example, in His Sermon on the Mount--seems too much for the Christian.

As a cry of the mature Christian, this cry expresses the dilemma of the Christian's life in general and reflects humanity's cry as a whole. The kind of solution that one brings to this tension will influence one's personal peace of mind, one's sense of success or failure, one's witness to Christ, and thus one's motivation for the sharing of Christ with other persons.'

See p. 21. 
It is well known that this predicament--and, therefore, the scripture, Rom 7:14-24, which describes it--have been viewed in a number of different ways. I contend that this plight need not be viewed merely as that of a person's pre-Christian life under the law as Emil Brunner seems to see it. ${ }^{1}$ Neither need one view the problem as the status of humanity under the law as this status is seen through the eyes of one whom Christ has freed from the law (Paul), as Rudolph Bultmann holds. ${ }^{2}$ The problem is rather to be seen as the actual situation of the Christian person in his day-to-day existence:

Paul does speak here (Romans 7:14ff.) of the Christian; but not in an abstract way. He describes the actual situation of the Christian--in this present world: there we face a dualism and the tension in the Christian's status. . . That dualism is not found in chapter 7 alone, al though many see it here particularly, and what is said here has received particular opposition. The very same dualism faces us in both chapter 6 and chapter 8. The parallelism in these three chapters can be outlined thus:

Chapter 6: We are free from sin--yet we must battle against it.

Chapter 7: We are free from the law--yet we are not righteous according to its criterion.

Chapter 8: We are free from death--yet we long for the redemption of our bodies. ${ }^{3}$

It is difficult to deny from experience or from scripture that this dua]ism exists.

${ }^{1}$ See Emil Brunner, The Letter to the Romans (Philadelphia: The Westminster Press, 1959), pp. 61-66.

${ }^{2}$ See Rudolf Bultmann, Theology of the New Testament (New York: Charles Scribner's Sons, 1951), pp. 245-248; Rudolf Bultmann, Romer 7 und die Anthropologie des Paulus, 1932, quoted (part in English) in Anders Nygren, Commentary on Romans (Philadelphia: Fortress Press, 1949), p. 287.

${ }^{3}$ Nygren, pp. 295, 296. The author gives a complete exegesis of Rom 7:14-24 on pp. 284-303. 
Thielicke goes on to say that the "ought" which attacks the conscience of a person through God's law actually goes for the jugular of human existence as a whole instead of "limiting itself" merely to "the radius of ethical action."1

Holding Thielicke's thought within the more limited bounds of the discussion (that of the Christian alone) and coupling it to the persuasive exeges is of Nygren, we must conclude that if in any sense humanity wishes to stand in innocence before God on the basis of the "I ought, therefore I can" (that is, on the basis of even a God-given skill in being obedient to God's law), no human will survive the Divine scrutiny. If one sees that the law of God and its radical claims upon human obedience proclaims the "I ought" not only to the realm of human action, but that it also says, "I ought" to be something other than that which "I am," then the human predicament is taken beyond the matter of day to day behavior or activity. It now speaks to something that cannot be remedied simply by altering behavior with reference to the law, even if that behavior change comes by the work of the Holy Spirit within.

The human predicament is not rooted in the top soil of what a person does or does not do with reference to the law, but in the substrata of what that person is or is not before God's holy law. This is not to say that the law has no interest in what a person does. But it is to say that what that person does before the law demands not only ethical or behavioral conformity but a radical obedience in every motive and thought of the person as a whole. At this point,

\footnotetext{
Thielicke, p. 143.
} 
humanity is really confronted with its innate dilemma. This is what the law must involve itself with. Because of what the human is, the wrath of God through the law stands against humanity. Here the phenomenon of the great and necessary change effected in a person as he or she becomes a Christian and remains a Christian, stands impotent. The change that occurs in human beings at the moment of their coming to faith is a radical and miraculous one, but that change does not create the quality of obedience in the person as a whole which is the law's ultimate command.

The Question of Human Sinfulness

Related closely to the moral predicament of humanity is a person's concept of what $\sin$ is. Gustaf Aulen says:

- . Christian faith knows of no division of man into a lower and sensuous part which is the seat of sin, and a higher and spiritual part which lie outside the area of $\sin$. When man is designated a sinner, it is a religjous judgment which has reference to man as a whole...

Aulen's argument is significant. Although sin definitely has to do with what might be called ethical points of view, that is, where the essential question has to do with the categories of good and evil or right and wrong, this merely ethical view of sin does not necessarily exhaust the realm of an actually religious view of $\mathrm{sin}$. In fact, when the concept of sin is removed from its "religious" setting to be placed merely in a casuistic setting of right or wrong, good or evil, then it becomes seriously weakened. The problem of humanity is not described acutely enough when only the descriptions

'Gustaf Aulen, The Faith of the Christian Church (Philadelphia: Muhlenberg Press, 1948), p. 260. 
of what is right or wrong are employed. When it is decided, even on the basis of an enlightened conscience, that certain patterns of thought or behavior are "good" and certain others are "bad," this does not plumb the radical recesses of what sin actually is. Further, when it is decided on the basis of a person's good or bad thoughts or acts that that person is good or bad, such judgments, even though they may be religious in nature, or apparently Biblical in their setting, do not fully sound the implications of the whole scriptural view of sin. When a person is designated a sinner on the basis of a "religious judgment" (using Aulen's terminology and meaning cited above), this designation has reference to that person as a whole. Such judgment reaches beyond the superfluous to the very "division of soul and spirit, of both joints and marrow, and [is] able to judge the thoughts and intentions of the heart" (Heb $4: 12$, NASB), because God possesses an instrument of judgment sharper than any instrument known to man. This instrument exposes human sin to a depth beyond the bounds of morality, ethics, or legality and opens to God's gaze the very core of the human soul (vs. 13).'

For this reason it is impossible even for Christian persons simply to consult their consciences, Biblically enlightened though

'Stated more concretely, The Interpreter's Bible, commenting on Heb $4: 12$, says, "For we do not know ourselves. We can never be sure of our motives, the intentions of the heart. We constantly seek good, or at least respectable, motives for all that we do. Under cover of these good motives all kinds of evil are at work. In this verse every human being is a hypocrite save he who knows that he is a hypocrite; and how remote that knowledge is from all of us! How we love to rationalize our conduct out of its reach." The Interpreter's Bible, vol. 11 (New York: Abingdon Press, 1955), p. 635. 
they may be, and accurately judge themselves righteous or unrighteous on the basis of their own behavioral or mental-emotional performance. Human beings are unable to be objective about themselves, and, far more significantly, they are unable entirely to comprehend the benchmark on the basis of which they are measured. Any self assessment must be recognized to be necessary but inadequate because of this. For this reason God must be judge and His verdict concerning humanity must be seen as the only true one now or in any eschatological assize. John Bunyan considers the nature of these assessments in his book Pilgrim's Progress as he puts Ignorance in conversation with Christian. As Ignorance is affirming the positive witness of his own conscience ("heart") which he attests is a "good" one and which tells him that he has left all for the service of God, Christian confronts him with the question:

But how dost thou prove that? . . .

Ignor: It comforts me in hopes of heaven.

Chr: That may be through its deceitfulness; for a man's heart may minister comfort to him in the hopes of that thing for which he yet has no ground to hope.

Ignor: But my heart and life agree together, and therefore my hope is well founded.

Chr: Who told thee that thy heart and life agree together?

Ignor: My heart tells me so.

Chr: Ask my fellow if I be a thief! Thy heart tells thee so! Except the Word of God beareth witness in this matter, other testimony is of no value.

Ignor: But is it not a good heart that hath good thoughts? and is it not a good life that is according to God's commandments?

Chr: Yes, that is a good heart that hath good thoughts, and that is a good life that is according to God's commandments but it is one thing, indeed, to have these, and another thing only to think so.

Ignor: Pray, what count you good thoughts, and a life according to God's commandments?

Chr: There are good thoughts of divers kinds. . . .

Ignor: What be good thoughts respecting ourselves?

Chr: Such as agree with the Word of God. 
Ignor: When do our thoughts of ourselves agree with the word of God?

Chr: When we pass the same judgment upon ourselves as the Word passes. 1

It is exactly at this point--the confrontation between the judgment of God in His word and the ethically informed conscience of religious persons--that the matter becomes crucial. It is here that one may well cry with the Psalm writer, "Do not enter into judgment with Thy servant, for in Thy sight no man living is righteous" (Psalms 143:2, NASB); or, "If Thou 0 Lord shouldst mark iniquities, Lord, who could stand" (Psalms 130:3, RSV). In the light of such cries the best of human ability to assess itself accurately recedes to a definitely subordinate position. Another old Testament cry implies that the same restraint be put on the validity of any view humanity has of itself: "The heart is more deceitful than all else and is desperately wicked" (Jer 17:9a, NASB). This statement continues with the rhetorical question concerning the human heart, "Who can understand it?" Verse 10 then resumes, "I the LORD, search the heart, I test the mind." The time never arrives when a person can with total accuracy schematize the extent to which she or he is right or not right. Human beings can and must necessarily assess themselves ethically, and these ethical assessments must be biblically grounded, but they must understand the gross limitations of such assessments when they are put into relation with God's ultimate assize. God's judgment of the human condition must be seen in terms of a revelation from God. It must be accepted as from God and

JJohn Bunyan, The Pilgrim's Progress (London: J. M. Dent and Sons, Ltd., 1907), p. 17. 
therefore, as perfectly true, just, and accurate. Even as all persons must accept God's word about them in the final judgment, so must they accept that word in the times before.

\section{The Struggle of the Christian}

A statement by Martin Luther now becomes especially relevant, "Quo sanctior quis est, eo magis sentit illam pugnam." 1 or, put another way:

The closer you come to Jesus, the more faulty you will appear in your own eyes; for your vision will be clearer and your imperfections will be seen in broad and distinct contrast to His perfect nature."

This assertion, along with Luther's raises an issue that is the corollary to the idea that the Christian is never able to satisfactorily appraise the actual extent of his own sinfulness or righteousness and must therefore accept God's estimate of him. The testimony of mature saints also attests to the accuracy of God's appraisal of them. A classic New Testament example of this is Paul's confession, made late in his life, "... And I am the foremost of sinners" (1 $\operatorname{Tim} 1: 15$, RSV).

If this confession of sinfulness is indeed true of the saints, then the matter of human sinfulness and the seriousness of the human dilemma are far more extensive than many have realized. Also, if it is true that at the end of an absolutely exemplary life one yet perceives himself as the chief of sinners, then it is demonstrated that

'See Aulen, p. 260; "The more saintly one becomes, the more one feels the struggle."

${ }^{2}$ Ellen G. White, Steps to Christ (Mountain View, Calif.: Pacific Press, 1908), p. 70. 
just as righteousness is like an ever opening bud, so is a person's personal sinfulness like something ever unclothing him. It is right at the acceptance of rejection of this fact that human beings must choose for themselves either one sort of solution or another. The solution that is chosen is critical for the life of the Christian and is (thus specifically) also crucial to the motivation of the Christian church.

So then, although persons may know what they ought to do, that knowledge does not make it possible for them to do it (Rom 8:3a). Though they know the requirements of the law, they yet find themselves, even as true Christians, continually coming short of them (Rom 7:15-19). This is the predicament of humanity and, in a special sense, of the Christian. The "ought," as far as the Christian is concerned, goes right to the core of human existance not limiting itself only to the radius of ethical casuistry. The dilemma deepens when it is seen that not even the Christian can penetrate his actual state in relation to this law. As Christian persons reach out by faith and the Holy Spirit to satisfy the law (and they must and will do this) rather than arriving at a place of complete fulfillment, they continually find more and more of themselves that does not coincide with the law's high demand. More and more is found in the law and less and less in themselves that can be pointed to as complete rightness. This is the constitutive pinnacle of the Christian dilemma. What is brought to the resolution of this inigma is vital to the way a person lives and 
conducts himself. It will influence the motives for ethical conduct and Christian service.

Implications for Human Motivation

Most of the definitions of what a "motive" (or "motivation") is have basic to them the idea of human need or desire. The need expressed in the dilemma of humanity generally is the need to be "self actualized" or "fulfilled," to have "status" and "esteem."2 The plight of Christian persons may be seen in terms of the need to be released from things that are a hindrance to self-actualization. As these needs are translated from a psychological to a spiritual language they may be expressed as the desire to be emancipated from wretchedness (Rom 7:24), to be liberated from the "law" which seems to evoke evil when all that is desired is the doing of good (vs. 21). Here is the desire for something that transcends the present condition.

Because Christian persons feel at odds with God and His law they are motivated toward some means of reconciliation with Him. The Christian realizes that even the thoughts, motives, and actions, are

It must be said emphatically that although the Christian continues to see himself as sinful, he is also deeply aware of his need to be ethically and pragmatically holy in all his ways. Although his ability to perceive the full extent of his predicament is seriously inadequate, his sense of what is right and wrong is entirely needful and functional as he lives by the Holy Spirit a life reflective of the ultimate standard of rightness. But just as the full reach of the law when cast in the light of the gospel is to the Christian a loving, though painful revelation from God, so is the balm that heals his soul--God's merciful assessment of him as perfectly well behaved because of the person and work of Christ.

${ }^{2}$ These terms are those used by Abraham Maslow (see p. 10). 
intimately known to the inscrutable mind of God. Not only this, but God is seen as the judge of humanity, the One who can and must remove life itself if a person does not find some means of reconciliation, some harmony with the law and a troubled conscience.

In this sense the law is "put in charge to lead us to Christ that we might be justified by faith" (Gal 3:24, NIV). The law arouses in the open mind a dissatisfaction, a need or desire for something better than what is presently possessed. If one takes God at all seriously, this plight is immediately actualized. It transcends any previous feeling of inadequacy and is accompanied by a profound desire for something better.

Further, this feeling of inadequacy never fully passes. It is kept in the most constructive tension with the complete adequacy of Christ who ever stands for the believing person. As the knowledge of the law of God in the light of the glory of Christ is opened to the maturing Christian, so is the tension existing between the "I am" and the "I ought." However, as believing persons come into contact with the rightness of Christ, standing in the sight of God as though it were their own, 'they are largely relieved of the fear factor within this tension. This relief, or resolution of fear, does not entirely remove the tension of the "I ought" and the "I am" but instead places it on an entirely different footing. Motivation no longer originates on the basis of a fear of not performing well enough to win the esteem of God. This performance is now possessed by faith in the Person and work of Christ. On the basis of Christ

ISee footnote 1, p. 29. 
and His work, the inner witness of the Holy Spirit evokes a desire to become like the One who is now loved and therefore obeyed.

The motivating tension--the desire, even the need always to be improving-- is yet present, but the fear which in itself was a motivating factor has essentially been replaced by a higher motive, one of different quality, one of love for God and gratitude for his liberating act of salvation. "For the love of Christ impels us" (2 Cor 5:14, Douay). Though the Christian's love for Christ does impel to action, it is the love of Christ for the Christian that is the prime motivational factor. The Christian's love originates and rests in the consistent initiatory love of Christ (1 John 4:10, 11, and 19).

For the maturing Christian, the reason for action rests not so much upon a desire to prove one's self as an achiever, ${ }^{1}$ but to being an achiever in the areas that matter most for the sake of Christ.

Although the Christian draws his motives for action from a deep love for the One who has redeemed him, he finds that this love is not always as it should be. Above all, the Christian finds his love is not perfect. Thus, in Christ, a healthy motivational construct exists: the Christian is moved pre-eminentiy by what he is always in God's sight because of Christ's love for him, and by what he continuousiy is not in himself. Here is a tension or "sorrow" that is the sorrow of a true repentance (2 Cor 7:8-10)--that which is

TSee David C. McClelland, The Achieving Society (New York: Irvington Publishers, 1961), pp. 36-62. Adaptation of McClelland's thought is made to the subject of this study. 
always needed ethically, spiritually, and motivationally in the human situation. It is a constructive, drawing sorrow containing the positive element of acceptance and full achievement in Christ. 
CHAPTER II

CHRIST AND THE HUMAN PREDICAMENT

The Relation of Christ to Humanity

In the previous chapter humanity as a whole was viewed as incomprehensibly at odds with God's law. Although Christian persons were seen as keenly aware and concerned about this dilemma, it was seen as the principle which constitutes the crux of the human enigma. In view of this devastating plight, Paul says,

It follows, then, that as the issue of one misdeed was condemnation for all men, so the issue of one just act is acquittal and life for all men. For as through the disobedience of the one man the many were made sinners, so through the obedience of one man the many will be made righteous. Law intruded into this process to multiply law-breaking. But where sin was thus multiplied, grace immeasurably exceeded it, in order that as sin established its reign by way of death, so God's grace might establish its reign in righteousness, and issue in eternal life through Jesus Christ our Lord (Rom 5:18-21, NEB).

Here, Paul views human beings as having access to a grace that "immeasurably exceeds" the farthrest recesses of the human predicament. God is seen as Himself acting to rescue. This act is seen to depend on a single man, the man Christ Jesus. The implication is that no other person and no other act could have achieved such a feat. The nature of the human dilemma demanded a solution exceeding the skills or resources of anything that any human being could conceive of. Given the impotence of the best of human conscience to understand the full extent of its dilemma or to find a viable means of 
liberation, someone logically had to act from outside the situation to effect a solution. So when Paul says, "For he has rescued us: from the dominion of darkness and brought us into the kingdom of the Son he loves, in whom we have redemption, the forgiveness of sins" ( $\mathrm{Co}$ ) $1: 13,14)$, he is proclaiming God's historical saving act through His Son as the means by which the release of humanity is secured.

Christ now becomes the great Center, the consuming preoccupation of the believer. He becomes the locus of all true doctrine, the affirmative hub of all the promises which God has made to humanity (2 Cor $1: 19,20)$. He is the capital of faith, the very reason for human hope. What He has accomplished becomes the believer's reason for existence. Christ's cross and the love demonstrated there becomes the believer's great motivating force.

Jesus is the Life of humanity (John $1: 1-4 ; 6: 47-55 ; 1]: 25$ ). Everything that any person might need to know about the profound perplexities of life may be found revealed in Jesus Christ. Jesus is Himself the revelation of God's purpose for humanity. Here, in one Man, is humanity as it was meant to be. In the one life of this one Man is the life that is required of all men and women. Jesus Christ is the inexhaustible Resource supplying all that the law of God could require but in which the best of humanity seems permanently deficient. Here is God among men, God audible, God visible, God touchable. Here is perfection made available to struggling people. Christ bears the judgment of humanity ( 2 Cor $5: 21$, Rom $8: 32$, 33). Because of the human antipathy to universal law, every person must die under God's judgment. But here in the person of this Man is the death of every person (1 Pet 3:18; Heb 9:28). In His death 
all humanity is incorporated, every person dies, while this death is offered to all as sufficient to redress their doom (2 Cor 5:14;

Rom $6: 10$ ). His death has removed the condemnation from those who by faith have perceived it (Rom $8: 1-4$ ). On the cross, God has provided completely for the fulfillment of any agreement concerning human salvation that was ever made between Himself and humanity. This death is the only one in the face of which it is appropriate to exclaim, "But God forbid that I should glory, save in the cross of our Lord Jesus Christ, by whom the world is crucified unto me and I unto the world" (Gal 6:14, KJV). For on this cross not only did He pay with His own blood the debt of humanity, but every person's death (specifically the "death" of the believing person), to this present aeon took place in Him so that the potency of its glitter holds no more authentic attraction in the face of a much greater glory ushered in by the new aeon He brought with him (Rom 6:10-14).

Jesus is the guarantee that humanity may rise from the tryanny of death. In this Man's rising from death, the dominion of death is forever devastated. His resurrection points to the rising of every person. His rise from death, His ascending to heaven is the resurrection and ascension of every person who will see this reality (Eph $2: 6 ; 1$ Cor $15: 12-28 ; 42-50$ ).

Jesus, then, is the history of humanity rewritten. In itself human history is entirely foreign to God's plan and government. In Jesus, human history is born and lived in entire conformity to God's plan. It is done in such a way as to preclude any accusation against those who choose by grace through faith to claim His history as their history. Jesus lived His life to the death with the purpose of 
providing it for humanity (Phil 2:6-8). In the case of the believing, it is actually He who calls it theirs, just as much as if they themselves had lived it out in the way He did. ${ }^{l}$ Karl Barth states this principle well:

The point to be grasped is that in Jesus Christ we do really have the new reality of world history... it is in this that world history really and properly takes place. This is not just a new opinion, view or theory. . . . It does not see in Jesus only what might be, or ought to be, or one day will be: it sees what is, what has come into being in Him and by Him. ${ }^{2}$

Jesus could bring this into being because with God He is God and Lawgiver and Judge. He is a]so Creator and Lord and Redeemer and Friend of sinners. He is before all things and He holds all things together. In him all God's fullness is invested. He is, as a human being, God available to the human. He is humanity available to God as it was destined by God to be. Jesus is, as Ray S. Anderson affirms, both the Man who is for God and the God who is for man. ${ }^{3}$ As such, He is at once advocate for humanity and forgiver of human sins, the canceller of all debts, the supreme force in His Father's hand

${ }^{1}$ The New Testament draws little if any distinction between the life and death of Jesus. There is certainly no separation made. It was the sinless living ( 7 ife) of Jesus that made His sacrificial death a perfect offering to God for human beings. This perfection is what the law required of every person. Death is the wage of those who deviate from the law's requirement. In the divine person of Jesus there was perfect human obedience, culminating in an obedience unto death. The whole of the person and work of Christ is offered as a gift of grace to humanity, while it is simultaneously offered to God as the means of honoring His eternal law and justice. This is crucial to the argument of Rom 5:12-21 (especially vss. 18, 19).

${ }^{2}$ Karl Barth, Church Dogmatics, IV:3 (Edinburgh: T. \& T. Clark, 1962), pp. 712,713 .

$3_{\text {Ray S. Anderson, Historical Transcendence and the Reality }}$ of God (London: Geoffrey Chapman, 1975), pp. 168-186. 
for the breaking down of all relational barriers. Yet He is altogether God, standing in man's streets and houses as the revelation of the character of God. He is King of kings and He is simultaneously humiliated Servant.

The Disclosure of God to Humanity

Jesus moved among people to reveal to them a Godly way to live. But Jesus did this by disclosing to them in living acts the character of God. This was done primarily as Jesus became the servant of humanity. As far as human beings are concerned, God is principally understood in terms of what He does, i.e., in terms of His acts, His work. Jesus reveals the heart of God when by His incarnation He demonstrates that God is willing and ready for condescension (Phil 2:5-8), for an act of apparent prodigality in behalf of hostile humans. Jesus reveals the extent of the love of God when, "being in the very nature of God" (Phil 2:6, NIV), He makes Himself nothing. When Jesus stoops not only to take on the nature of His creature, but in doing so, to assume the role of the creature's servant, finally subjecting Himself in humiliation to the hostility of His creatures as they crucify Him, Jesus reveals God to human beings. This is no metaphysical or theoretical disclosure. This is not done to impress man with the gods. The revelation of God in Jesus Christ is a down-to-earth disclosure of the character and thought and especially the love of God for humanity. This cannot be mistaken by the open onlooker. It is concrete and understandable, for it is "said" by a Word that human beings can see and hear and hold. Through the prophets in "various ways" (Heb $1: 1$, NIV), God 
spoke to humanity. By the prophets the coming of Messiah was avowed. In the Hebrew sanctuary service, the work of Jesus was prefigured. But it was only at the arrival of the reality Himself that the real disclosure of God occurred. Although God had moved in mighty acts of liberation for humanity in the community of Israel, Israel did not fully see her freedom until the liberator Himself stood among them. The history of the Hebrew nation is a holy chronicle of how God acts in behalf of His people. As God fashioned each of the major acts of Israel's history there was the disclosure of a God who acted for humanity. But more significantly, Israelite history became holy in that it contained, having acted out in prophetic shadow, the saving acts of the One who embodied its true life--the Messiah. He disclosed vividly in visual, audible terms what God was really like. When He came He was not only the fulfillment of the word of God expressed through Israelite history, prophecy, poetry, and song, but He was the Word made flesh, the same that was in the beginning with God, the same by whom all things were made that are made (John $1: 1-3$ ). Jesus was God's eschatological Word. He was God's Word expressed finally and fully. There was nothing that could have been added to what He disclosed concerning God. With Him was the inauguration of the "last days" (Heb 1:2a, NIV). Any further revelations are insights proceeding from the glory of that unique revelation. God has spoken to us by His Son (Heb $1: 2 b$, NIV); what more would God have to say in terms of the actual disclosure of his plans and thoughts after such a Word had spoken? This is a Word which is "the radiance of God's glory and the exact representation of his being" 
(vs. 3). The knowledge of the glory of God is in the face of Jesus Christ (2 Cor 4:6).

In Jesus God has set up His kingdom. The kingdom has come in the person of the King (Matt 3:2, 4:17; Luke 17:20, 21, RSV). The earth is His. All pretenders for the planet's rulership are just that. With the inexorable stepping in of the Son of God these pretenders have been dethroned. Jesus has done this by casting down the one He called "the Prince of this world" (John 12:31, 16:11, KJV). Jesus rules in the new aeon--by a government which reflects the character of the king. Here is justice--the kind humanity has always sought. Here is peace--the kind that people have always craved. Here is love: pure, selfless and rauical, evoking obedience in the daily living of those who are a part of the kingdom.

Jesus Christ discloses the sovereignty of God. This is not a sovereignty that is displayed only in the choosing of the subjects for His Kingdom, but it is unfolded in His life as a whole.

God's sovereignty was most completely portrayed on the cross. Even as principalities and powers took Christ and judged Him guilty of death, even as the rulers of the darkness of this world seemed in sovereign domination, "God was in Christ reconciling the world unto Himself" (2 Cor 5:19, KJV). Even as He subjected Himself to death at human hands, those very hands were pursuing the ultimate will of God. While it was given to creatures to act out their freedom to do their worst, they were unwittingly carrying out God's best. They left their work, satisfied that their plans had been crowned with success, unaware that they had brought to maturity the sovereign plan of God for human salvation. 
On the cross Jesus "discarded the cosmic powers and authorities like a garment; He made a public spectacle out of them and led them as captives in His triumphal procession" (Col 2:15, NEB). There can be, then, no situation, desperate as it may seem, where God is not Sovereign King. Even the humiliating road to Golgotha becomes, as Stainer's Crucifixion puts it, "the royal way." The cross itself becomes His "throne" from which flows mercy and righteousness, justice and judgment. Christ hanging on the cross is the clearest disclosure of God. Christ on the cross is the Gospel.

Christ As Coming King

The Kingdom of God, though disclosed in Christ at His incarnation and representing what God is, is not yet visible in the sense that it will be. The kingdom is yet seen only with eyes of faith. It awaits the physically visible breaking in of Jesus, the Parousia. The whole creation waits for the final disclosure (Rom $8: 23$ ) when it will see ultimate reality face to face, when "I" shall know "even a) so as I am known" (1 Cor 13:12, KJV).

If the eschaton was inaugurated at the coming of the Messiah to literal Palestine it will be consummated at His second coming when all is unveiled in the final judgment of the world, when that which has been hidden is opened to view, when the sons of God are revealed and the children of darkness are shown for what they are (Matt 25:31-46; Rom 8:16-23). This has been described as follows:

At that day Christ will be the judge. Every secret thing will be set in the light of God's countenance. . . .

Sinners will then see their sins without a shadow to veil or soften their hideousness. . . But those whose life is hid with Christ in God can say, "I believe in him who was condemned at Pilot's bar and given up to the Priests and Rulers to be 
crucified. Look not upon me a sinner, but look upon my Advocate. There is nothing in me worthy of the love he manifested for me: but he gave his life for me. Behold me in Jesus. He became sin for me, that I might be made the righteousness of God in him.

At the time of the actual appearance of Christ, the decisions of a judgment that has already occurred, will be revealed and acted upon. There will be no case from the believing community nor any aspect of any case that will have been judged aside from the Atonement made for that person by his Savior. Judgment will be executed according to the works of the human, but in the case of believers, never apart from the decisive work of Christ effected by Him at His first advent. 2

This is the time of the great separation. It is the time when the results of the celestial intercession are divulged and substantiated, when those who have declined the proviso of God are by their works revealed as separate from those who have accepted it by faith. It is the deeds of humanity that are judged and exposed. The question is whether or not those works reveal a relationship of faith in the Savior-Judge. The final judgment is a time which has been preceded by a unique and especially potent call of God to living mankind which says, "Be ye therefore ready..." (Matt 24:24ff., KJV), "behold the Bridegroom cometh, go ye out to meet him" (Matt 25:6, KJV); and "the hour of God's judgment is come" (Rev 14:7, KJV).

IEllen G. White, "The Price of Our Redemption," Youth's Instructor, May 19, 1900, p. 2.

${ }^{2}$ Although the New Testament definitely envisions a final judgment according to works (e.g., John in Rev 22:12; Paul in 2 Cor $5: 10$ and, most significantly, Jesus in Matt 25), it holds the good news of the operation of grace through the work of Christ to be the salvific element in that judgment. This emerges as it is realized 
The certainty of the fulfillment of the promise of the parousia rests upon the record of God's absolute veracity demonstrated especially in Christ. Certainty does not find its roots in the fulfillment of even the best of the schemes of prophetic interpretation. These fulfillments act as confirmers of faith, while faith itself rests in the specific promises of God; promises ratified by the cross event. Thus when there is apparent delay in the parousia, the saints look to a verity consistent with the core of God's word. ' The certainty of the parousia is established in the person and work of Christ as sovereign Lord. He is the One who has never failed to act when He has promised to do so. He could not fail

that no additional principle is brought to bear in the New Testament when final judgment is discussed. The good news of God's grace is not only that past sins are forgiven through Christ, but that there shall be salvation from the wrath of God through Christ's saving activity (Rom $5: 8-10$ ).

In John 3:18 judgment is seen as occurring at the first advent in connection with the person of Christ. This judgment occurs on the basis of whether or not a person believes in the only begotten Son of God. This statement concerning judgment is intimately tied to the magnificent gospel proclamation of verse ?6. (See vss. 14-21 for a clear exposition of judgment in relation to faith and works.) In John 5:22-24 judgment is seen as an accomplished fact for the believer. This is put in direct connection with vss. 25-29 which deal with the resurrection at the parousia (vss. 27, 28) and again a judgment according to deeds (vs. 29). In John 12:31 judgment is again seen as being decisive in connection with Christ (first advent). It must also be noted that in Rev $14: 6,7$ the angel carries the everlasting gospel to the whole world (vs.6) as he announces that the hour of God's judgment has come (vs. 7). In other words, it is the saving principle of the gospel that is seen to be that which is potent in the face of final judgment. This principle is seen to be the very element which brings hope to the believer at any point of the divine judgment process.

The attempt is not made here to draw a distinction between God's word as a whole and God's prophetic word. Rather a distinction is being drawn between God's word and the somewhat complicated and involved schemes of prophetic interpretation that quite often shock the community of faith, or cause it to wonder when they fail or seem to need more than a periodic revamping. 
because of His sovereign omnipotence. In other words, this promised return finds its authenticity in the fact that Christ has come once as He promised and that the very nature of that first Messianic arrival demands the great unveiling at His second coming.

In summary, Christ has acted for both the human and the Divine. He possessed that embrace which could reach the recesses of the human plight while it grasped the throne of God's justice. He was the one who broke quietly into human darkness to bring it into a kingdom of light. He did this by living the life every human was meant to live and dying the death humanity was meant to die. Thus, as the forerunner of humanity, He was raised to the place where $\mathrm{He}$ means humanity to be. He was all human history, as well as all human future. In Him is the fullness of human personhood and all the fullness of the Godhead. He is Victor over all that might stand arrayed against humanity. He is the perfect disclosure of God. He is all Israel incorporated into One. He is God's final Word. He reveals the sovereign omnipotence of God. He is also the king who comes as Judge. When He comes the second time all He effected as historical Messiah will be unveiled before the whole creation. He comes to claim those who are revealed as His by a judgment according to their works. This judgment reveals, by a Divine preadvent inquest into the works of human beings, whether the provision of the judgment at the cross has been fully assimilated or not.

\section{Motivational Implications}

The most effective and satisfying human motivations are activated as one assimilates the who and the what of the person and work 
of Christ for humanity. It is not as though other motives appear any less efficient in terms of actually producing positive and active behavior, but it is that a more drawing, less driving sort of motivation comes into existence. Good behavior and the communicating of one's faith with others occurs on a level of "want to" rather than "ought to," though "ought to" is yet a viable motive. Whereas previously one was motivated more from a need to escape guilt and find esteem, now one is motivated more from the perspective of a gratitude for that which grace has done, and from the position of already possessing the esteem of God. Basic fulfillment in Christ is now a reality, and one is no longer driven by what might even be seen as an involuntary need for self-actualization. One has the sense of belonging, of safety and security because of the accomplishment of that Other. Godly activity arises from a base different to that from which it previously proceeded.

As Christ's personal rightness is seen to be the source of human rightness, the center of concentration moves from the consideration of the ethical casuistries of Christian living and becomes occupied with a new Locus. The reason for being Christian is no longer only the doing of good works as such, but the revealing of the love and salvation of Christ to others. Life is not seen as being gained because good behavior is dominant in it, but good behavior becomes dominant in it because the Lord of life is seen by the believer to have acted (and is yet active) for the believing person. It is not out of fear of death or the need/desire for eternal life that favorable activity proceeds. It proceeds rather because Christ has defeated guilt and death and it is consistent and only right that 
man should live and move accordingly by faith through the Holy Spirit out of a sense of immense gratitude.

Previously, things have seemed impossible to achieve. Even in claiming the Spirit's power to work out in the life behavior that which God esteems fit for his kingdom, the life has still come up short. Now because of Christ the starting point is one of achievement, and the demotivating ' roadblock of never being able to achieve is removed. Hence motivation is placed on a far more effective footing. The strength of the achievement motivation is thus increased. A nominal level of conflict and failure is motivating, but beyond the bounds of a certain threshold too much failure and inner conflict is definitely demotivating. ${ }^{2}$

In connection with this it is revealing to view adaptively

a statement by Abraham Maslow:

If all the needs are unsatisfied, and the organism is then dominated by the physiological needs, all other needs may become simply non-existent or be pushed into the background. It is then fair to characterize the whole organism by saying simply that it is hungry, for consciousness is almost completely preempted by hunger. All capacities are put into the service of hunger satisfaction, and the organization of these capacities is almost entirely determined by the one purpose of satisfying hunger. ${ }^{3}$

From this it might be inferred that if the fundamental spiritual needs have not found a satisfactory level of resolution in

" "Demotivating" is used here and elsewhere in this study to denote the opposite of what is motivating. In other words, whereas some stimuli may tend to cause a person to act constructively others will tend to discourage such action.

${ }^{2}$ See Bernard Weiner, Theories of Motivation (Chicago: Rand McNally College Publishing Company, 1972), pp. 226-230.

3 Maslow, p. 37. 
the case of a Christian person, if the Christian yet struggles, for example, with the need for a resolution of guilt and has not found how God has dealt with this in Jesus Christ, then he or she will tend as a spiritual "organism" to be preoccupied with the desire to resolve this one need. Though for some time this unresolved need may be motivating, if no means is found for resolving this, it will turn into something highly demotivating to that person. This need for guilt resolution can easily come to control the whole being of the Christian, blocking out the recognition of other needs or desires that could otherwise surface to move the person to a more productive existence. Though such a dominated person may appear for some time to behave very similarly to other Christians who may have to a greater extent resolved this guilt question, the reasons for action and the inner cognitions are considerably different.

In moving to the issue of the second coming of Christ, it may be observed that the parousia has always had implications highly suggestive from a motivational point of view. When the Christian church, or any segment of it, has been highly sensitized to the imminence of the second coming of Jesus, great enthusiasm has resulted and expressed itself in phenomenal church growth patterns. Conversely, as this sense of urgency has declined so has the phenomenon of a highly motivated community.

The idea of "facing the judgment" tends to tempt the church into appealing to the motive of fear. This manipulative stance

IThe New International Dictionary of New Testament Theology, ed. Col in Brown (Grand Rapids: Zondervan Publishing House, 1967), $2: 921-927$. 
almost always ignores the centrality of the first coming of Jesus in relation to His second coming. When the implications of Christ's judgment in behalf of the world upon His cross are lost sight of, the fear implications of the final judgment can most easily be played upon. The whole idea of "getting ready for Jesus to come" becomes a dominating drive to the serious initiate particularly, and this motivational force easily drives him through fear to a type of religion that is not healthy.

The more driving motivation, "get ye ready," is different from the more drawing one, "be ye [a1so] ready" (Matt 24:44), especially when the ongoing condition of being ready is seen to be achievable on the basis of the work of Christ at his first coming. At this point the sense of urgency, so basic to Christian motivation, is maintained while the sometimes neurotic fear motive is removed. The certainty of the second coming of Christ is not seen to rest upon the fulfillment of "the signs of the times," but upon the immutable covenant word of God. It is with this more concrete assurance that the eschaton is announced to the world as immiment. " This certainty evokes productive motivation, a motivation that cannot wane when time seems to continue beyond the originally expected point.

Aside from these considerations, the aspect of the splendour of Christ as a man, His love and magnificence, is a great motivational force to the Christian, to act as He acted and behave as He did.

This is not to say that the fulfilling of the "prophetic word" of God is to compete with his "covenant word"--these two are actually one. A distinction in emphasis is what is suggested. 
Further, when Christ is seen as sovereign Lord, the fear of what may happen in the world, or the fear of whatever may threaten an individual, is diminished (Psalm 46; 56:4; etc.). Fear, depending on its nature or intensity, can be either motivating or demotivating. It is clear that much of what might actively be done in the service of God is not done because of fear. When God is seen through Christ as sovereign, much of this demotivating fear is removed, and work otherwise left undone, is done. 1

A summative, thesis statement can now be made. It was on the cross of Christ that the pardoning love of God opened up for humanity a complete salvation (Rom $3: 23-26$; Col 2:13-15). This pardoning activity of God in and through Jesus Christ is foundational to the motivation of Christian people. This has been expressed as follows:

The apostle Paul says, "When I am weak, then am I strong." 2 Cor 12:10. When we have a realization of our weakness, we learn to depend upon a power not inherent. Nothing can take so strong a hold on the heart as the abiding sense of our responsibility to God. Nothing reaches so fully down to the deepest $t_{2}$ motives of conduct as a sense of the pardoning love of Christ.

Paul says this of his own motivation (1 Cor 15:9, 10).

Though he had persecuted the church, God's grace (i.e., "pardoning love") had made him an apostle. It was due to this grace, Paul says, that, "I worked harder than all of them" (vs. 10, NIV). This was Paul's ultimate motivational appeal when dealing with local Christian

I Some of these demotivating fears may be fear of failure, fear of the unknown, fear growing out of ambivalance as to how, in a practical sense, the work of witness should be approached.

2 Ellen G. White, The Desire of Ages (Mountain View, Calif.: Pacific Press, 1898), p. 493. (Emphasis supplied.) 
churches. In Rom 12:1, for example, he says, "I urge you, brethren, in view of God's mercy, to offer your bodies as living sacrifices, holy and pleasing to God" (NIV, emphasis supplied). This verse follows a magnificent exposition of God's merciful dealing with Israel $(9: 1-11: 36)$ and is immediately preceded by a doxology in view of the wonders of God's dealings with humanity $(11: 33-36)$. Integratively living in the light of this pardoning love extended to the Christian in spite of failure, is the factor which elicits a great gratitude. This gratitude is crucial in motivating the Christian toward the exact opposite of failure--a life filled with the fruits of Godly activity. 


\section{CHAPTER III}

\section{CHRISTIAN LIFE, THE RESPONSE TO SALVATION}

This chapter attempts to answer the questions raised and the dilemmas discussed in chapter I (The Human Predicament). This will be done by bringing the contents of chapter II (Christ and the Human Situation) directly to bear on the issues raised, faith being the main link. "Faith" here will be limited to the faith which is related to man's salvation in the Christian context. In this setting the work of the Holy Spirit in the believer's life, along with the Spirit's relation to the work of Christ, will also be discussed. The chapter will close with a discussion of the motivational implications resident in those aspects under consideration.

The Nature and Exercise of Faith

Christian faith is not positive thinking. It is not a principle which when exercised in the human mind brings about, because of some mysterious psychic connection, some desired result. Faith is not an isolated principle by means of which things begin to happen. Christian faith does not have its genesis in the human or in anything terrestrial. Nor is this faith ethereal or mystical though it does deal with that which is eternal and supernatural. Faith is not a skill or an art that is learned, that only the initiated can exercise. 
Christian faith is a living, active principle because it has as the object of its concentration a specific living, active Person, His word, His promise, His faithfulness, and His unchangeable love. Faith can only be validated by means of that upon which it is fixed. In the case of salvific Christian faith, not only is a Person the object of faith, but it is the actual work of a Person that becomes that which faith rests upon. Further, not only is it the Person and His work that is the object of Christian faith, but this Person and His work are humanly historical and are therefore embedded in the concerns of humanity and are relevant, reasonable, and understandable to human minds.

Ephesians 2:8 and Rom 12:3 speak of faith in terms of God's gift to human beings. Philippians ]:29 says, "For unto you it is given in behalf of Christ, not only to believe on him, but also to suffer for his sake" (KJV). In Gal 5:22, faith is listed among the fruits of the Spirit and in 2 Pet $1: 1$ it is seen to be "obtained... through the righteousness of God and our Saviour Jesus Christ" (KJV). Thus faith is a gift given to human beings by God, by which it is possible to grasp the reality of the person and work of Christ, His salvation, promises, faithfulness, and love.

The New Testament would rather, it seems, describe saving faith than define it. These scriptural descriptions are numerous and might take a straightforward verbal form (John $3: 16$ ), ' a metaphorical form (Matt 11:28-30), or the form of a human, 01d Testament example of saving faith (Rom 4). Jesus used the parabolic

${ }^{l}$ Faith and belief are not held to be sufficiently distinct from one another to merit any discussion of their discreteness. 
method to describe faith (Matt 17:20).

The historical metaphor used by Jesus in John $3: 14-16$ is most applicable to the purposes of this study. Here Jesus depicts the belief that grasps eternal life (vss. 15, 16) as being that which simply looks to Him like the dying Israelites looked to the brass snake in the days of Exodus. In the exercising of this faith, there is no baffling mystery to block the way to belief, and no barrier to the liberating personal assurance that comes with saving faith. When saving faith is seen to be more or less than what this metaphor implies, then that sense of assurance and confidence before God, which is so important to a highly motivated life of Godly activity, is robbed of its potency. James Buchanan summarizes this when he says,

Protestant divines have generally held that the assurance of personal salvation is attainable in the present life-that, so far from being injurious to holiness, it is eminently conducive, not only to the believer's comfort, but to his advancement in the divine life--to his cheerful discharge of every duty. . . . since it is founded, not on any presumptuous confidence in the strength of his own resolution, or his own abi]ity to persevere, but on the faithfulness of God's promise, and the unchangeableness of Christ's love.

Through faith in the word and the work of Jesus Christ, a person enters into a relationship of pardon and personal actualization within the full esteem of God. This relationship lifts believing persons form the demotivating sense of condemnation and chronic failure. It is a relationship of liberation accompanied by a distinct sense of belonging, acceptance, and assurance that comes through faith in God's word of promise. Its early effects are seen

J James Buchanan, The Doctrine of Justification (Grand Rapids, Baker Book House, n.d.), p. 377 . 
as those living within the relationship begin to view themselves in a more positive light and begin to view others according to the way they, by faith, see that God because of Christ is viewing them. Having had their need for belonging, for esteem and self fulfillment met, they are freed by this to extend to others the same Godly attitude which has made them whole. ${ }^{1}$ Because of the quality resident in the object of faith, this relationship can be initiated and maintained. Because there can be absolutely no relenting in the covenant demand of God's law, God has provided the personal rightness of the man Christ Jesus, for human faith to look to. (Num 21:8; John $3: 14,15$.

This saving faith (that comes as a gift of God through the Holy Spirit, and that looks to the person, the work, the word of Christ, His faithfulness and His unchangeable love) throws significant light upon the way in which saving faith is exercised. The "how" of faith is crucial to the motivation of Christian people. For, if indeed Christian action springs from an assured faith, then the way of exercising this faith is vital to the motivation of Godly activity in the Christian community. If the "how" of faith is a mystery, then the way to Godly activity is also frustratingly mysterious.

When the "how" of faith is dealt with, it is important that

'Matthew 18:23-35; 1 John 2:6; 4:1-13; Eph 5:1, 2; Col 3:17. Although the "ought" (see p. 12ff.) of Christianity is strongly present in these passages, its thrust rests always in that which Jesus is, that which He has done for humanity. Christian persons will tend strongly toward Godly activity as they find the motivation for it in an assimilated, faith-filled view of what God has done for them in and through Christ. 
the "who" question underlie the whole query. Looking to the "who" actually reveals the way of the "how." When the "how" is looked at this way, the question of faith or belief tends to extricate itself from the involved descriptions of the mechanics of what the human being must do or not do in order to bring about the feeling of faith or even the reality of faith. The how of faith is inextricably one with the "who" or the object of faith. This seems to have been the way that questions of faith were generally presented in the New Testament. ${ }^{1}$

If the premise articulated above is valid, the how of faith consists mainly in receptively hearing ${ }^{2}$ the accounting of the acts of God as the voice of the Holy Spirit in that word speaks it (frequently, through a human agent). As Kornelis Miskotte has said, "No religion can be transmitted by narration; but faith lives, today as always, by the telling of that which the Lord did then and in such and such a way on earth. . . ." 3

There are some considerations that further expose the how of faith. Faith has to be seen as fixing itself upon the acquiring of the specifically promised gifts of God. When one abandons the notion,

IAs one looks at the sermons of Jesus, of the book of Acts generally, of Paul specifically, or the writings of the New Testament as a whole, there is little involvement with the question of how faith is exercised. Instead Christ is proclaimed, and those open to Him hear and believe.

"By "receptive hearing" is meant a hearing which involves more than the act of mere physical hearing. It is the kind of hearing that involves a whole-hearted response. This quality of hearing is spoken of in Heb 4:1--the hearing mixed with faith.

${ }^{3}$ Kornel is H. Miskotte, When the Gods are Silent (New York: Harper and Row, Publishers, 1956), p. 206. 
so natural to human thinking, that some activity on the part of the human being himself is necessary before faith can take God's gift, then the major roadblock to the exercise of faith is removed. When the nature of Christ's work for humanity is heard in the kerygma, then the human being sees that the gift has already been given and may actually be acquired without money and without price. Saving, active faith can begin to operate. when, in the proclaiming of the good news, the Word is heard that every requirement has been met and every barrier has been demolished in the works of Him whose accomplishments have been entirely approved by God. As this is seen to be true, it is also seen that every reason for approaching God with confidence has been given in the holy history of Jesus Christ. As believing persons see by faith that their rightness stands perfect at the throne of God in the person of Jesus, ${ }^{1}$ they have every reason to be dauntless in the humble presentation of themselves, their praises, and their needs to God (Heb $4: 14-16 ; 10: 19-21$ ).

The how of faith, then, has much to do with the nature of faith. Faith rests in the word of promise affirmed in the acts of God. The "how" of faith does not find its answer in the skillful practice of certain clearly delineated techniques. Instead, it finds its answer as it directs its gaze at the Word of promise, and toward a simple knowledge of the One who has spoken that Word. This is faith's subject matter. To explain how to believe in God is to explicate the wonders of Christ so that as the Spirit speaks, faith comes to life in action. At the moment faith comes to life, by its

John Bunyan, Grace Abounding to the Chief of Sinners (Boston: American Tract Society, 1905), p. 129. 
very nature it must know the "how," or it will not be actual biblical faith but some other puzzling entity that needs intricate explanation before it can begin to function.

In other words, faith is something which by its nature does not need to know how to exercise itself, but needs instead to hear the word of Christ through open ears for it to come to life and begin its saving function. As Christ speaks, the gift of faith brings the man of hearing to wholeness as it did the paralyzed man by the pool of Bethesda when the Word of Christ shattered his doom, and he got up and walked.

\section{The Holy Spirit and Christian}

\section{Behavior}

Encountering the personal goodness of Christ as a living principle produces a profound life-altering experience. Though it is vitally important to distinguish between the work of Christ for humanity historically, and Christ's work in human beings at the present, it is of just as great importance that the work of Jesus for a person and His work in that person be seen as a work done by the same One and for the same purpose--that of making one more than conqueror through Him who loves us. Though it is vital to distinguish between the work that is perfect, complete, external, historic, and Christ's alone, and that work which is imperfect, incomplete, internal, present, and a human work under the Holy Spirit, it is just as important to see that these aspects are existentially bound together in an inextricable unity. The right doing that saves (i.e., Christ's) is quick to show itself in the life of the saved. Though the life of the saved is ever imperfect, it is reflective of 
the Life that saved it. This reflection is disclosed primarily in the way that life relates to other believing human beings (John 13: 35 ) and to the world community (John $3: 16$, Matt $5: 44$ ). The saving action of Jesus Christ by its very nature evokes (motivates) a reflective saving action on the part of the saved. When believers are (because of Christ) treated by God as though they were perfectly right and Godly, the tendency is for them in every day life to act accordingly. This is crucial to the dynamics of Christian motivation. ${ }^{1}$

The whole person has sinned and it is the whole person that God wishes to make godly. Louis Berkhof has described this present work of God in humanity as follows:

Sanctification may be defined as that gracious and continuous operation of the Holy Spirit, by which He delivers the justified sinner from the pollution of $\mathrm{sin}$, renews his whole nature in the image of God, and enables him to perform good works.?

Berkhof has chosen his words carefully. The matter of holy living is an action that flows continuously from grace ("gracious") by the supernatural influence of the Holy Spirit. By it the

${ }^{1}$ This statement is based upon the thrust of Rom $6: 1-12$. In calling for the power of the reign of $\sin$ to be broken in the believer's life (vs. 12), Paul appeals to that which Christ has done as being crucial to the reason for Christian activity along this line (vss. 6-11).

${ }^{2}$ Louis Berkhof, Systematic Theology (Grand Rapids: William B. Eerdmans, 1941), p. 532 . 
believing person is freed from the contamination of $\sin ^{2}$ This is a radical and effective work which reaches into every part ( 1 Thess $5: 23$ ) of the human being causing good behavior (though not sinlessly perfect behavior) to result. This definition and another by $A$. H. Strong, for example, is consistent with others. ${ }^{3}$ of significance: "Sanctification is that continuous operation of the Holy Spirit by which the holy disposition imparted in regeneration is maintained and strengthened." 4

The renovating love of an indwelling Holy Spirit has highly practical effects on the life of believing persons. Perhaps above all it has the effect of making the receiver of it a more loving, that, is, self-giving, person (Gal 5:13) with all the implications that this has for behavior in general. The obedience brought by the Holy Spirit is one that "realizes itself in conrete

$1_{\text {Berkhof evidently uses the word "delivers" in what might }}$ be called the "present continuous tense." This is consistent with the remainder of his teaching on this. Ibid., pp. 527-544.

${ }^{2} A$ statement by Victor Paul Furnish is clarifying: "Nowhere does Paul say that sin has, as such, been abolished. It is not sin but the sinner who has 'died' (Romans $6: 2,10$, 11 ; cf. $7: 4$, death to the $\left(\frac{\mathrm{aw}}{\mathrm{l}}\right)$. To speak of being 'freed' from $\sin (6: 7,18,22)$ implies that sin still seeks to enslave, even though, being 'dead' to it, one no longer stands under its dominion (vs. 14). The same thing can be said of death. . . . One may say that Paul speaks not of the Christian's freedom from sinning, but of his freedom from the power of sin. V. P. Furnish, Theology and Ethics in Paul (Nashville: Abingdon Press, 1968), p. 173.

${ }^{3}$ Note, for example, Ellen $G$. White, The Sanctified Life (Washington, D.C.: Review and Herald, 1937), pp. 7, 9.

${ }^{4}$ A. H. Strong, Systematic Theology (London: Pickering and Inglis Ltd., 1907), p. 569 . 
living in all the acts of the man of faith." The mind of such a person is becoming one with the mind of God, endeavoring to expel every known sin and keep every known command of God. Desiring to be peaceful, patient, gentle, temperate, and self-controlled, such a person wi11. Tive by the Spirit in constant view of the fact that everything hostile to good behavior has been crucified with Christ on His cross (Gal 5:22-26; $2: 20$, NIV; 2 Cor $5: 14$ ). This realization disciplines while at the same time it encourages and motivates the bel iever.

Paul stated it this way: "But we all with open face beholding as in a glass the glory of the Lord, are changed into the same image from glory to glory, even as by the Spirit of the Lord" (2 Cor $3: 18, \mathrm{KJV})$. This is a necessary change, as Heb $12: 14$ points out: "Follow . . holiness, without which no man shall see the Lord" (KJV). Revelation 21:27 states it, "There shall in no wise enter into it anything that defileth, neither whatsoever worketh abomination, or maketh a lie" (KJV).

A] though the Holy Spirit is the prime mover in this work of remaking the life of the believing person, this work is by no means done without the effort of that person. Human effort is clearly required to co-operate with the work of the Holy Spirit in the life. God, through the Holy Spirit, does work in the human to will and to do (Phil 2:13), but He does not perform the willing or doing for

${ }^{1}$ Rudolph Bultmann cited by Thomas C. Oden, Radical Obedience, The Ethics of Rudolph Bultmann (Philadelphia: The westminster Press, 1964), p. 91 . 
the human. ${ }^{1}$ For this reason the work done by the Spirit in the life cannot be seen, per se, as a work done strictly for the believer in the same sense that the work of Christ on the cross was done without the believer's participation. For this reason also, though the internal, renovating work of the Spirit is necessary in the salvation process, it is not meant to be, nor can it be, that which produces an obedience radical enough to cause the salvation of the believer. It is rather seen as the very necessary result, or outcome of the historic saving work of Jesus.

Another element in the process of radically altering the life of the believer is the aspect of "truth" and/or the "word." Jesus prayed, "Sanctify them through Thy truth: Thy Word is truth" (John 17:17, KJV). Paul spoke of, "the word of His grace, which is able to build you up and give you the inheritance among all those who are sanctified" (Acts 20:32, NASB). This word of grace (pardon) is used by the Spirit to refurbish the life, to make all things new in it. In a real sense the word also conveys the Holy Spirit to the believer. This word is in essence, "the word of the truth of the gospel" (Col 1:5, KJV). The Spirit bears witness to Christ; He witnesses to the forgiveness that Jesus brought. The Spirit thus becomes the Spirit of life for He always points to Him who is Life.

The Holy Spirit is forever directing the world to the saving activity of Jesus Christ, which has made possible the forgiveness of sins. In the parable of the two debtors and its setting (Luke 7:

IEllen G. White, Messages to Young People (Nashville: Southern Publishing Assn., 1930), p. 147. 
36-50), the dynamic motivating force of God's forgiveness in Christ is illustrated as being that which is critical to a practical love for God which shows itself in deed and action. The crux of the parable is found in verse 47 , where Jesus says of the woman, "And so, I tell you, her great love proves that her many sins have been forgiven; where little has been forgiven, little love is shown" (NEB). As forgiveness is continuously being received, the recipient is continuously showing practical acts of loving, Godly activity. These acts are the effects of Christ's forgivness in the human life through the Spirit.

The Holy Spirit is directly influential in the motivation of the people of God to Godly activity. This is shown in the book of Acts. It was not as though there was no kerygmatic activity before the day of Pentecost, but there was an apparently different base of action after Pentecost with different, more wide-spread results. 1

It is also not left for the believer to wonder about the socalled receiving of the Holy Spirit. The Spirit is received on the same basis as is every other gift of God--by faith (Gal 3:1-14). It is the cross that has made the believer eligible to receive the Spirit (see vss. 13, 14). This is not a thing of mystery though it involves mystery.

When it comes to the practical means of living obediently, this is delineated by Paul in Romans 6 . The underlying question of the first part of this chapter may be phrased, "How do we discontinue sinning?" Paul sees it as illogical that the believer should live

'Compare the activity of the followers of Christ before Pentecost to after Pentecost. Compare Luke 10:1-20 and Acts 2:1-47. 
in sin. Not only is it illogical, but in the light of the work of grace it is incongruous, even preposterous (vss. 2, 3). Paul goes on to root the practical issues of daily Christian living in the essential historical saving acts of Christ as illustrated in Christian baptism. "Therefore we have been buried with Him through baptism into death, in order that as Christ was raised from the dead through the glory of the Father, so we too might walk in newness of life" (vs. 4, NASB). Paul exposes the crux of his teaching when he says, in speaking of the death and resurrection of all men that took place in Christ (vss. 9, 10), "Even so consider yourselves to be dead to sin, but alive to God in Christ Jesus" (vs. 11, NASB). Paul sees that in God's estimation, the believer has died to sin and risen to a new existence. It is fundamental to defeating sinful acts and to incorporating positive Godly activity into the life, that this consideration be seen as God's estimation of the believing person. If this is believed, sin cannot (will not) be allowed to "reign in your mortal body that you should obey its lusts" (vs. 12, NASB). On this basis ethical Christian behavior takes place. Existence is yielded as an instrument of righteousness to God (vs. 13) thus reflecting the one successfully yielded instrument. As faith is exercised this way it becomes dynamic as a behavior-modifying force. ' The Holy Spirit convinces the believer of the truth of God's estimation of Him in Christ and leads him to a deeper and more penetrating grasp of this estimation, and thus to a constantly maturing form of ethical behavior.

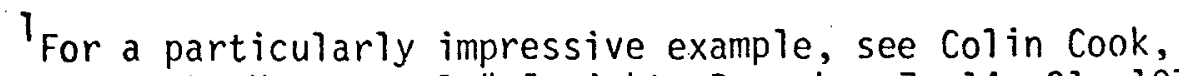
God's Grace to the Homosexual," Insight, December 7, 14, 21, 1978. 
It is to all practical purposes inevitable that within such a dynamic the believing person will proclaim in his own way and by his own Spirit-given gifts the good news of an ever new experience. It is ultimately as it was with Elijah on Mount Carmel. Though the enthusiasm of Baal's priests seemed to some as a holy activity brimming with charism, it was Elijah's quiet appeal to the sacrifice presented in faith that brought the holy answer with fire. This was an answer from God that had visible consequence. In terms of Godly activity, there can be no more lucid evidence of the Holy Spirit's presence than when individuals are pointed to and moved by the sacrifice which takes away the sin of the world.

Implications for Human Motivation

The objective nature of faith has serious motivational overtones. When Christian faith is called for, but it is clouded in the mysterious realms of complicated "how-tos," then there are few who find that they can exercise it. Thus it loses its motivational force, and moves no one to action. If faith is represented as something that requires the attaining of a certain skill level before it can be effective, then it tends to be seen as the unattainable possession of the few, the initiated. The man of the street may look at it for a given length of time and then surrender his interest in it as though it were out of his reach. But when faith is seen as something that centers in a Person--and at that, in a Person of objective human history--and when that Person is "1ifted up" (Johh $3: 14 ; 2: 32-34$ ) as the object of faith, faith comes to life by the Spirit and it is no longer a mystifying, unattainable skill or a thing some receive 
while others are left out of the benefits of its exercise. 1

As believing persons see that the "how" of Christian faith rests in clear, specific, biblical views of the "Who" of Christian faith, the inability to exercise faith is reduced and thus a definite roadblock to Christian motivation will be removed. These persons will not only exercise faith, but they will be eager to tell others of their discovery. When within the Christian community itself "bringing a person to Christ" is seen as just that, stripped of any arcane elements, then Christians will feel more able and thus more motivated to bring other persons to Christ. In other words, having become possessors of such a faith themselves and understanding it with existential significance, Christians are far more able and thus more motivated to express their faith to other human beings.

The faith that centers in the person, and word, of Jesus Christ is a faith that has accepted the means by which the sin and guilt of the world is removed. The people who, for example do not attend church or cease to attend church because they perceive themselves as "not good enough" are largely those who are blocked by guilt. The same block seems to bar the way to the potent witness that many feel unable to give because of it. Therefore, when persons rest themselves in a work that has removed all such barriers, the blocks to highly motivated ministry are removed. Forgiveness received by faith evokes loving service, involving a witness to the

${ }^{1}$ For a fuller discussion of the effects of experiencing certain levels of frustration in achievement and its consequences on human motivation, note Bernard Weiner, Theories of Motivation (Chicago: Rand McNally College Publishing Company, 1972), pp. 253, 254. 
Object of that faith. This kind of faith is at the core of Christian motivation.

In an overall sense the certainty and assurance that this kind of faith brings onto the human scene is fundamental to its motivational force. Uncertainty grows from the fear of failure and inhibits action. Certainty prompts one to act or causes one to be far more likely to take positive action. Though certain struggles and uncertainties continue at times to baffle the Christian person, this assured quality of faith provides a core of certainty conducive to strongly motivated activity.

In order to remain effectively motivated, a person must experience a satisfying level of observable success or achievement. 1 If persons have been assured that a high level of "victory" will be theirs through their relationship to Christ, failure to achieve a certain success at this point will lead them into a demotivated state in which they might pretend to succeed, or persuade themselves that they are indeed succeeding, or withdraw in disillusionment and guilt, or give up entirely. If, through the sharing of the good news, a given time period elapses with no visibly achieved success, the levels of motivation decrease accordingly and in fact tend to reverse themselves so as to cause the believer to avoid witnessing activity, motivated this time by a fear of failure rather than the hope of success (achievement).

At this point the existential understanding of the relationship of the work of Christ to the Holy Spirit and the dynamic nature

\footnotetext{
'See Weiner, pp. 201-203.
} 
of faith are essential. If constant failure is experienced on the fronts of both personal, day-to-day living and in the area of "soul winning," a pattern of defeat and demotivation easily sets in. Thus, persons need to experience the sense of ongoing forgiveness and total achievement through the work of Christ in their behalf. The need is also very great, however, for that evident self-actualization and fulfillment that comes through cooperation with the Holy Spirit as a result of faith, when a person actually has daily success in living in a Godly way. To experience this on a relatively ongoing basis is to enhance the motivational thrust. The failure which is at the same time constantly felt, so long as it is not chronic, and so long as it is clearly seen to be covered by the vicarious work of Christ, is also enhancing to the degree of motivation because of the challenge that remains, and the ever present possibility of a higher level of achievement.

Beyond this it is the Holy Spirit's work as He enlightens, comforts, convicts, draws, indwells, unites, teaches, leads, assures, seals, assists, enables, confirms, and transforms that evokes such impetus in the Christian. The Spirit is Himself the motivator of the church's and of the individual's activity thrust.

As the Holy Spirit applies the word of the gospel primarily as presented in scripture to the life of the believer, the incentive for action is inspired. The Word has a way of raising the level of desire for achieving. It creates needs and meets those needs as an ever living and providing source. The Spirit and the Word working together through faith tend to compose the most compelling construct motivationally speaking. 
In summary, in order for a healthy degree of motivation to exist, a person must experience a certain degree of unfulfilled desire or need while at the same time a satisfying degree of resolution of desire is felt. This is well supplied by the wholistic biblical concept of salvation.

Although speaking to the case of children, the following is helpful to the human scene as a whole:

The child must be given goals about which he can do something immediately, and reach relatively soon. As each one is reached, a higher one must be discovered for him. Soon, each attainment will become in itself the stimulus for a new task. New visions will be constantly leading him on to new achievements.

${ }^{1}$ Ernest M. Ligon, The Psychology of Christian Personality (Schenectedy, N.Y.: Character Research Press, 1975), p. 39. 
CHAPTER IV

THE BELIEVING COMMUNITY IN THE WORLD

The Divine Determinacy of the Church

In the final analysis the church can have no viable identity outside of Christ who is her Head. The metaphorical language of 1 Cor 12 is suggestive. The church can have no life if she is not deriving her reason for existence, her direction of action, her unity, co-ordination, and expression from her Head. From the ministry of Christ, the church's ministry is determined. God chose to act in the earth with ultimate primacy in the person of His Son. This Son has raised up His community, consisting of those entering into God's Covenant through Him, to represent among themselves and in the world at large His reconciliatory ministrv.

The implications of this divine determinacy are clear. The whole world is to be viewed as Christ viewed it. . This perspective transcends any "worldly point of view" (2 Cor 5:16, NIV). The church is the community of Christ's new creation and it is with this in mind also that all things are to be viewed. This kind of world view is consistent with the fact that "the new has come" (vs. 17), and with the fact that "all this is from God" (vs. 19) who, having removed through Christ the guilt of sin from the world has thus made peace with the world. This ministry of peace God has committed to the church. He has given to the church, that is, to those who have 
recognized their Christ-forged peace with God, the same ministry. This ministry specifically consists of the proclaimina the good news to the world that God, through the pivotal deed of Christ, has fashioned a saving peace between Himself and the world. ${ }^{1}$ God has extended favor $(6: 2$, NIV) to a world in His disfavor, having made His perfect Son the sin of the world in order that He might bring the world to the position of the rightness of His Son. It is this ministry that the church serves from within as it exists in the world. It exists to implore the world to "be reconciled to God" (vs. 20, NIV). This was the ministry of Christ while historically incarnate, and is yet incarnational in the person of the community which ministers by the Holy Spirit the same work.

This community is to express its ministry in the down-toearth situations of its particular time and place. By the Holy Spirit it must offer to God a service worked out in its own contemporary setting as Christ did in His; for such a ministry is in fact the organ of Christ's expression in the here and now. The reconciliation that the community of faith has discovered as existent between God and man because of Christ will be expressed in the breaking down of social, cultural, racial, economic, and personal barriers in the world. While the church seeks to do this, however, it keeps before it the uniqueness, distinctiveness, purity, and holiness that it always must unselfconsciously exhibit.

The church finds its ministry determined by Christ in other

"This is not a "universalist" view. If God were adopting such a stance there would be no need for him to give to the church the ambassadorial (vs. 20) duty of sharing with the world the accomplishments of Christ in the world's behalf. 
ways. Having the mind of the self-emptied, the humble form of the servant, the solidarity with the world's sinner, the sacrificial obedience "unto death," this makes the church's service a valid service of Christ (Phil 2:1-11). It is not as though this work is done solely for the sake of an obedient reproduction of the kind of ministry Jesus did. It is that having taken on by faith the character of the Saviour, the community of faith comes to be disinterestedly a saving community. Having been radically altered and affected by the saving message of Christ, the community becomes an irrepressible herald of that very message. It comes to avouch to the world that in Christ is the life and the light of humanity and that in Him, human history takes place properly.

Thomas F. Torrance speaks of Christ as being, through the Holy Spirit, present in His church in such a way as to make the church "his own Body or his earthly and historical form of existence." 1 This Body lives only as it takes on the life of God. Life flows out through the Body to all humanity, as the church fulfills the mission of Christ in bringing to the world hope, light, love, reconciliation, and the summons to obey the gospel.

The pattern of the ministry and mission of the church is to be found in Christ's divine-human person. The church does not exist as an independent entity, nor even does it exist as a separate construct of the Holy Spirit's making. It exists through the Spirit solely because of its elemental relation to Jesus Christ. Although the church has its humanly traceable history, its diverse polity,

${ }^{1}$ Thomas F. Torrance, Theology in Reconstruction (London: S.C.M. Press Ltd., 1965), p. 193. 
its worldwide dispersiveness, it is yet conclusively the kingdom of Christ, having found and always finding its determination in Him.

The Intrarelatedness of the Church

Fundamental in the discussion of the intrarelatedness ${ }^{1}$ of the church is the principle of what has traditionally been called "the priesthood of all believers." This principle is one that has its roots, at least in its Protestant Reformation form, in the soteriological formulations of that upheaval. It was Luther's conviction that the New Testament and its teaching has put all people within the Christian community on an equal footing before God. Since all find salvation upon the same basis, all stand equal in the sight of God, even though the Christian community may confer upon some an office different to that of others. ${ }^{2}$ The idea that all are kings and priests (1 Pet 2:9) and that all are equally parts of the same body with only one Head (Rom 12:1-8 and 1 Cor 12:1-31) has, aside from other considerations, significant motivational implications.

It is crucial that in arriving at the conclusion that every member of the Christian community is equal in his stance before God, that one see the soteriological basis for such a conclusion. Without this the principle becomes rather barren and subject, when tested, to a rapid compromise. Further, motivationally speaking, it is largely robbed of its potency, for it tends to be held in a merely

"Intrarelatedness" here refers to the dynamics of the inner life of the church as a community.

${ }^{2}$ See, for example, Martin Luther, "The Freedom of the Christian," in Three Treatises (Philadelphia: Fortress Press, 1960), pp. 280-293; and "An Open Letter to the Christian Nobility," in Ibid., pp. 14-24. 
dogmatic manner with little actual freedom for it to exercise its dynamic force in the community.

In summary form, the soteriological basis for the equality of all members of the believing Christian community may be described as follows:

1. All have sinned and are continually coming short

2. There is no one who at any time can, on the basis of good behavior, produce that which saves

3. God in merciful love has sent His only Son to accomplish the reversal of this predicament

4. This work of rescue has been completely and singlehandedly accomplished in history (so that no one can add to it or subtract from it) by God's Son, Jesus

5. All who have entered the Christian community have entered through faith alone--a nonmeritorious principle.

6. It remains permanently true that in God's sight all continuously share and maintain their vital right to membership through a common Source and by a common means--that of Christ by faith

7. In Christ alone, the only head of the church body, resides rulership and administration, justice, and vindication. At His cross every human being stands upon even ground with every other.

It is important to note at this point, however, that "God has appointed first of all apostles, second prophets, third teachers" (1 Cor 12:28) and then numerous other functions for the equipping of His church. There are then some whose spiritual gift invests them with a role that is a leading one in the community. They are to be respected and obeyed (Heb 13:7), though they maintain their role 
legitimately only through their Christian servanthood (Luke 22:26, 27) and their constant confession that Christ alone is Lord and Head of His church. The validity of Christian leadership is maintained in the integrative understanding of the great central principles of the Bible: God, Christ, Holy Spirit, Scripture, Man, and Reconciliation. The Christ-accomplished freedom of the Christian community rests in Christ's hands, and to a significant extent in the ongoing realization of all in the community that this is so. This realization is essential not only for the one whose gifts cause him to be a leader, but for the community as a whole.

The inherent tension of Luther's famous statement is helpful to the church: "A Christian is a perfectly free lord of all, subject to none. A Christian is a perfectly dutiful servant of all, subject to a11." "Through the ministry of Christ by faith every believer is a free "lord" sitting in heavenly places in Christ Jesus (Eph $1: 3$ ). He has become one of the "royal priesthood" in the kingdom of Christ (1 Pet $2: 9$, NASB). As such he is subject only to Christ. But because every other member of this new community has received the same privilege, for the same reasons and upon the same basis, and because of the very nature of the kingdom, the believer is also a servant of all (Luke 22:24-27). The church is definitely a theocracy; the people of the kingdom are the people of the King--ruled by Christ alone. There is no human being, even though he be an "Apostle," whose role it is to mediate in any sense between Christ and the believer; but there is no human to whom the believer is not servant,

\footnotetext{
IMartin Luther, "The Freedom of a Christian," p. 277.
} 
and there are those humans who, by Christ and the authority of His word, are to be "obeyed" by virtue of their office.

The church, then, holds to the equality of all in the Christian community on the basis of the principles of the New Testament gospel. When these principles become blurred, then the foundation, and ultimately the practice of the community as a whole, becomes uncertain on the question of human equality. ${ }^{1}$. The extent to which the rank and file of the community is integral to the whole life of that community has significant ramifications for its existence, even its interest in its own destiny.

The liturgy and mission of the church, along with its every expression and its life as a whole, has the need, therefore, of consistently respecting and reflecting that which is fundamental to its theology. As a community's expression, its life forms cease to reflect its theological affirmations; it becomes susceptible to significant changes in its theology. On this basis both the theological and pragmatic expression becomes dulled and ineffective. ${ }^{2}$ When this occurs, the community's goals and ideals are undermined, and the effect on the motivational dynamics of a congregation are necessarily negative.

${ }^{1}$ See Langdon Gilkey, How the Church Can Minister to the World Without Losing Itself (New York: Harper and Row, 1964), pp. 61-73, 96 .

${ }^{2}$ See William Hordern, Living By Grace (Philadelphia: The Westminster Press, 1975), pp. 20-23. 
The Church's Relation to the World

The church addresses its own community and the world community as a whole. Speaking to both of these communities is crucial to the life of the church (and to what occurs in it from a motivational viewpoint). In either case that which is "heard" from the church depends not only upon what is verbally articulated, but also upon the attitudes and expressions in the life of the church.

The church's attitude to the world has had critical implications to the church's understanding of its mission, its whole approach to the world, and thus the motivational dynamics behind its thrust into the world. While the church has seen its need for maintaining its purity and separateness from the "worldliness" of the world, not loving the world (1 John 2:15), it has at the same time seen its commission to go into the world (Matt 28:19), loving the world as God does (John 3:16).

Deitrich Bonhoeffer talks of the "colossal obstacle" of a large part of traditional Christian ethical thought which he says conceives of the church (holy and supernatural) and the world (profane and natural) as two distinct spheres which are in hostile conflict. In this conflict, the preoccupation of the church is with the proper relation of itself to the world ethically, while concern for the reconciliation of the world to God and His church becomes distinctly secondary. Bonhoeffer goes on to say that when Christ and His relation to the world is made the church's essential 
consideration, this "two sphere" tension is placed in a form which is definitely more manageable. 1

So the question is, How did Christ relate to the world, or what was His attitude to it? The reality that ultimately needs addressing here is not so much the church's self understanding, nor the church's understanding of the world, nor even the matter of ethical or moral standards and values, as important as these are. The reality always ripe for discussion in the church, and at some times acutely urgent, is the reality of God's relation to the world as He has revealed it Himself in Jesus His Son, and thus as He wishes it to be manifested in the life of the church today.

It was over the issue of what ethical or moral goodness was that Jesus came into the sharpest conflict with the best religiousness of Judaism. ${ }^{2}$ Jesus successfully reconciled that which was apparently irreconcilable. He introduced the church to an entirely unique way for the good to meet with the bad.

To understand the uniqueness of Jesus' relation to the sin of the world, one must understand Jesus' gospel. Jesus' confrontation with the Scribes and Pharisees, for example, in Luke 15:1, 2,

'Dietrich Bonhoeffer, Ethics (New York: The Macmillan Company, 1955), p. 62 .

${ }^{2}$ A study of the fundamental issues at stake in Jesus' conflict with, for example, the Pharisees of His day, will not be undertaken here. Joachim Jeremias in his book, The Parables of Jesus (New York: Charles Scribner's Sons, 1954), pp. 124-26, persuasively shows that the major gospel parables of Jesus were not merely addressed to the sinner, but were addressed to the Pharisee or even the Sanhedrin in "defence and vindication of the gospel; they are controversial weapons against the critics and foes of the gospel who are indignant. . a and whose special attack is directed against Jesus' practice of eating with the despised." 
is representative of a number of other similar confrontations. The Pharisees' view of $\sin$ and the world prompted them to make their accusation, "This man receives sinners and eats with them" (vs. 2). In reply, Jesus tells those three parables so revelatory of God's gospel, of His attitude to the world of sin and sinners (Luke 15:4-32). Both the Pharisaic accusation and Jesus' parabolic reply is a significant challenge to today's Christianity and its view of the world. The thrust of the passage is lucidly illustrative of the kind of attitude called for by God. This scripture puts into concrete understandable terms the ideal mindset for the church when dealing with the world. It is a mindset or attitude directly responsive to the nature of the New Testament gospel.

If the church fails to relate as Christ did to the world, its witness in the world is drastically reduced, and that under the most virtuous of auspices--those of preserving the highest standards of Christian conduct. In fear of allowing the opposite and no less dangerous extreme (that of relaxing the rules in laissez-faire style) to dominate, the actual relationship of the church to the world and its sinners is negatively affected.

The church must stand in defense of the world in the same way Jesus did. The church must mix with the world in the same way Jesus did. The church must love the world in the same way Jesus did. The church must share the same good news with the world in the same way Jesus did. This doing of things in the same way Jesus did should not, however, consist of a blind following of His example. The church must integratively and existentially grasp what Jesus was and what He was actually about in the world. This is 
entirely possible as the church comes to a living knowledge of the gospel that Jesus taught and that Jesus was.

In regarding the church and the world as two mutually exclusive entities, the recognition of the original ideal relationship of these is lost. The recognition not only of Christ's view of the world, but of what He accomplished by his death in reconciling the world to God (2 Cor 5:19) is also blurred. Thus the mission of the church is not viewed clearly. The mission of the church is seen as consisting largely of condemning ${ }^{1}$ the world for its sin. This mission is seen at best as pressing the world to reconciliation with God, rather than proclaiming to the world an accomplished reconciliation in Christ ${ }^{2}$ and earnestly inviting the world to participate in the reality of this.

The tension between the church and the worid is forever present. Corruption within the church comes because the world is within the church, by virtue of its membership which is in the world. The church is always threatened by the dual danger of secularization and sacrilization. ${ }^{3}$ The preservation of the church depends upon the Head of the church, and in a different sense, upon the way the church relates to its Head in regard to the world. The motivation of the

'Condemnation of the world is seen here not in terms of "pointing out sin," which is a vital church function when judiciously administered.

${ }^{2} A$ universalist meaning is not applied here. The sinner must accept the reconciliation of Christ in order to be reconciled.

${ }^{3}$ See Karl Barth, Church Dogmatics (Edinburgh: T. \& T. Clark, 1958), 4:2, pp. 667ff. Secularization--the world in the church in destructive relation. Sacrilization--the church in the world in destructive relation. 
church, when it comes to the living of a holy life and in its witness to the world, is highly influenced by its fundamental attitudes about the world.

Motivational Implications in the Life of the Church

As the community of faith has held before it its divine origin and determinacy, its sense of impetus for growth (in quality and quantity) becomes inevitably more accute. When believers carry an ongoing sense of divine origin and actually believe that their reason for existence and their command to "go" are from a divine source, their motivation to go is considerably more potent than if they believed it to be simply their pastor's commission to them. When the vital sense of the divine source or origin of the church has shifted, the church's sense of responsiveness must also shift. When the church's reason for acting in a constructive way finds its genesis merely in a human plan, goal, or organization, seen to be communicated merely by human lips to fulfill human desires, then the body is less likely to act positively, especially over a protracted period of time. When a sense of the divine determinacy of the church and its mission is present in the church, it is likely to act more fully, more effectively, and more durably. As Michael Green says: "In a word, Christian evangelism has its motivation rooted in what God is and what he has done for man through the coming and the death and the resurrection of Jesus."'

Not only does the commission of the church need to be

TMichael Green, Evangel ism in the Early Church (Grand Rapids: William B. Eerdmans, 1970), p. 237. 
perceived as of divine origin, but it needs to be, as was "the great commission," clear and specific. There were few ambiguities present in Jesus' charge to "go". (see Acts 1:8b). It did not appear impossible, for the Lord himself had promised to be with those commissioned, in the person of the Holy Spirit. (Matt 28;20, Acts 1:8a), and they experienced early success in their mission because of this.'

Further, there is a demotivating influence present when the members of an organization are unable to contribute their input in the function of the organization. This would be especially so if they felt that it was their right to contribute. When significant input is sincerely sought from the Christian community, their needs for social affiliation, status, esteem, and self fulfillment are met, and they are able to seek higher forms of self fulfillment--for example, involvement with others in a life of caring ministry.

When in the church setting, the community attests by the way the church is structured that it believes the gospel of Jesus Christ, e.g., that all are on a completely equal footing in Christ, that a11 in fact are kings and priests, with all that this involves, then the door is opened for a highly potent, less self oriented motivational construct. At this point servanthood is not only psychologically desirable, but it is sought after as a logical step in the motivational hierarchy. Intrinsic motivation is far more likely to occur in such a climate.

'George H. Litwin and Robert A. Stringer, Motivation and the Organizational Climate (Boston: Harvard University, 1968), pp. 4565 , point to the need for individual responsibility, support, specific expectations, and organizational identity as ingredients for an effective motivational climate. These were clearly present in the first century Christian era. 
Basic to the roadblocks (i.e., demotivating aspects) to Christian witness in the community of faith is the often contradictory message that is given by the church as its leaders attempt to motivate the body to go into the world and make converts. One must go into the world to save it, yet one must stay out of it for fear of corruption. One must love the world, and one must not love the world. Even though Scripture is clear as to what it means by such apparently contradictory orders, often the church is not. Though the scriptural orders are positive in their thrust, the church's articulation of them is often given with the emphasis on the fear of contamination, rather than upon the saving of the world. It is imperative that on the basis of the carefully investigated ministry of Jesus Christ, the church carefully remove from its membership the restrictions that impede the motivation of the believer to go into the world sharing the liberating good news. 


\section{CONCLUSION}

The motivational roots of human action are to be found where human needs are most acutely felt. It is at exactly this point that God meets with people. Psychospiritually speaking, the dilemma of humanity is that it has, through deviation from God's will, come to lose its true self--its sense of security or belonging, its sense of positive regard (esteem) in the eyes of God, its fellows, and itself. Besides this it has been largely robbed not only of its sense of self fulfillment, but to some degree, its ability to reach a state of satisfying personal fulfillment. Among the most pressing of the needs of persons is that they find some authenitc means by which these losses may be regained. The desire to have these needs met is powerful and universal and accounts for much of human behavior and the reasons (motivations) behind that behavior.

Although on the human scene itself, a variety of means for meeting these needs have been proffered, God in the person and works of His Son Jesus Christ, has, with intentional consideration for the motivational psychology of human beings, voluntarily gone to the heart of human need. In the singular, divine-human life, death, and resurrection of Jesus, God, in loving justice has pardoned human beings. In the same activity God has provided every person who will believe witn all the rightness needed to stand before the uncompromising law of God in complete innocence. 
Thus through Jesus Christ humanity has been supplied with a sense of "sonship" (Gal 4:4-7; I John 3:2), that is, a secure sense of belonging. God in Christ has devastated those barriers to belonging, that estrangement which was caused through a deviation from His will. Further, God has chosen to look at human beings who believe in the same way that He views His Son. Believing persons thus come to perceive that in the esteem of God, they are "beloved" and "well pleasing" (Matt 3:17). All of this is basic to the self-fulfillment of the human spirit. As God's historic, saving activity and His pardoning love are by faith integrated into the lives of people, the motivation for greater service is opened up, and thus an everexpanding sense of self fulfillment is experienced.

Certain valuable insights emerge when Abraham Maslow's hierarchical view of human need is seen in the light of God's saving work. Maslow feels that it is only after the "lower," physiological needs have been regularly and dependably met, that the human being can become susceptible to the "higher," more psychological need-motivations. Once the physiological needs of persons are being met, these needs can afford to adopt a less dominating role in the framework of human motivational dynamics. An important latitude is created by the meeting of these needs. . This latitude is quickly taken up by the demands of higher, more psychological needs (i.e., belonging, esteem, and self-fulfillment). The meeting of the "lower" needs and their associated motivations and activities is the dynamic which opens the way to the function of higher motivations and activities. Until the "lower" needs have been dependably met, it is unrealistic to expect that the activities associated with "higher" 
need reduction motivations will be forthcoming.

Similarly, one cannot expect Christian persons to produce Godly activity (especially Christian witness) while basic psychospiritual needs remain largely unfulfilled, or fulfilled to an uncomfortably inadequate extent. A certain positive consciousness is needed, a certain platform of security from which a person can reach out to do the works of God. This has been supplied in the person and work of Jesus Christ. In the man Christ Jesus, those needs that are otherwise dominating drives directed at meeting inward, self-directed satisfactions are (have been) authentically met. To the extent that the Christian community integratively experiences this reality, it will be free to participate in a genuine manifestation of Godly activity.

An illustration of this from the life of Jesus is helpful. John 13:3-5 says., "Jesus, knew that the Father had put all things under his power, and that he had come from God and was returning to God; so he got up from the meal, took off his outer clothing ... and began to wash his disciples feet" (NIV). The implication here is strong, that it was the knowledge of Jesus' relationship to the Father, the knowledge of where He had come from and where He was going, that "enabled" Jesus to act as servant toward his disciples. A similar certainty, which comes by faith in Jesus Christ through the Holy Spirit's work, will be that which enables the Christian to participate in such activity.

Finally, this faith will show itself in the way the church as a community relates within itself and to the world. Instead of being controlled by purely self-fulfilling, esteem and rejection 
avoidance motives, and because of its security in Christ, the church will tend rather to be moved by motives that transcend these.

It is imperative to note that, because of the sinfulness still haunting all human nature, and because of the environment in which each member of the believing community exists, that the community must continue to rehearse and to regularly remind itself of the splendid reality of who it belongs to, what it is esteemed to be because of Christ, and what the source of its fulfillment actually is. This must be done not only by word of mouth, but each facet of the life of the church must be designed so that it expresses and consistently brings to mind the realities of what God has done for humanity in Jesus Christ. Some suggestions of how this might be done in the local congregation, with emphasis on the motivational implications of such a task, will be the theme of Part II of this study. 
PART II

THE APPLICATION OF A CHRISTIAN VIEW OF HUMAN MOTIVATION TO THREE DIMENSIONS OF THE LOCAL CHURCH 


\section{INTRODUCTION}

It is urgent for the contemporary church that it continue to lay solid theological foundations upon which an effective practice of ministry can be built. It is equally urgent that every article positioned in the practical ministerial structure be placed in proper reference to that foundation. In other words, the theological foundations and the structures of ministry cannot be dealt with in isolation from one another.

An attempt has been made in Part I of this study to lay a theological foundation. The task in Part II is to allow what has been said theologically (and psychologically) to inform the practice of local church ministry in such a way that the resulting structure will be theologically solid while it is serviceable to the actual call of everyday life.

In doing this, the thesis of this study (the pardoning love of God in Christ that reaches most deeply and effectively into the motivational recesses of the human soul), will be applied to three varying aspects (dimensions) of local church existence. The first of these will deal largely with the pastor's own motivations as he moves to bring the congregation into specific forms of behavior. The ethics of human motivation will be discussed with a view to that which makes certain motivational appeals healthy and legitimate and others not. 
The next chapter will deal with the spiritual aspects of motivation. The spiritual needs of the congregation (with the three "upper" levels of Maslow's hierarchy of needs in mind) will be discussed, plus the motivational stimuli by which the fastor may reach and appeal to the congregation. The way in which the Christian gospel meets these needs and opens up new motivational avenues will also be discussed.

The final dimension of church life which will be covered is the church's organizational dimension. Here again the needs of the congregation will be viewed, though this time from the angle of the church's involvement in decision-making, planning, and executing its activity. The motivational values of possessing specific goals and clearly delineated plans for meeting those goals will be discussed along with some of the demotivating roadblocks to constructive activity. The motivational implications of the Christian gospel (the pardoning love of Christ) will be further exposed, as it is allowed to permeate the organizational structures of the church. 


\section{CHAPTER I}

THE ETHICAL QUESTION IN HUMAN MOTIVATION

The Question of Ethics in the Use of Motivational Stimuli

In dealing with the question of ethics as it relates to human motivation, this chapter will be limited to two fundamental considerations: 1) What is one's own reason for attempting to move persons into specific forms of thought or behavior? 2) What means are employed as this is being done?

Essential to this study as a whole is the conviction that human need is foundational to the question of motivation. 1 Human need is that force which causes human activity or effort. ${ }^{2}$ It is clear that without activity or effort very little would be achieved by individuals or organizations. John Hinrichs uses the work of McClelland and Atkinson ${ }^{3}$ to propose that the need for achievement ${ }^{4}$ is the most critical within organizations generally. ${ }^{5}$ It may then be

1 Pages 5-8.

2John R. Hinrichs, The Motive Crisis (New York: AMACOM, 1974), pp. $43-45$.

${ }^{3}$ David McClell and and John W. Atkinson, The Achievement Motive (New York: Appleton-Century-Crofts, Inc.).

${ }^{4}$ The achievement drive is seen to be closely related to the need for esteem and self actualization.

${ }^{5}$ Hinrichs, p. 44. 
postulated that the need to achieve would be critical in those who worked within a given organization and that this need is present in the church and is likely therefore to be highly significant to its life and thus to the lives of those who work within it. ${ }^{1}$ As one combines the achievement need that the normal minister feels within his organization, with the areas of achievement by which the organization tends to guage its success or failure, one may quite readily see how a minister might be heavily driven by the need to achieve. It is undeniable that the achievement need is first of 211 normal and, further, that it is crucial to any quality of organizational life, or to life in general.

Other considerations, however, are important. In looking at the membership of the local church, other explicit or implicit needs may be observed. It is entirely possible that under the pressure of a heightened achievement need, the best intentioned minister may use these needs of his parishioners as a means of moving them into activity intended to enhance the minister's achievement quotient in the sight of the church organization. The ethical questions aroused by this possibility are representative of the concerns that must be faced when motivational principles are being implemented on the local church level.

Other related questions are: Could one become so ethically conscientious that viable, natural, or legitimate motivational stimuli are bypassed resulting in an impractical, ineffective

This statement is inferred on the basis of the thinking of McClelland and Atkinson along with John Hinrichs. Reflecting carefully on the church in this regard will reveal sufficient confirmation of this. 
ministry? Upon what basis may a minister know when he is running out of ethical ground in his motivational appeals?

The primary question of this chapter is, How does one pragmatically apply the motivation of "the pardoning love of Christ, "] in the local church while the high demands of Christian ethics are at the same time being met?

The Question of Manipulation

in Motivation

Manipulation in this study is defined as the course of action taken by one person to control the behavior of others while those others are not aware of the reasons behind the action or of the fact that the activity they have become involved in has been designed to benefit the manipulator. An underlying question, therefore is, What is one's own reason for attempting to move persons into specific forms of thought or behavior?

Manipulation is a controversial concept mainly because it is difficult to decide when certain persuasive (or motivational) techniques are being legitimately employed and when these same techniques slip into the arena of what may be seen as manipulation. Further, while one person may view a certain motivational course of action to be manipulatory, another may not.

The manipulator, and the person who might be called the gentle persuader, have in common the desire to change the behavior

The phrase "pardoning love of Christ" comes from Ellen G. White, The Desire of Ages (Mountain View, Ca.: Pacific Press Publishing Association, 1898), p. 493, and is here used to summatively describe that which is seen in this paper to be foundational to Christian motivation. (See also pp. 75, 76.) 
of others. This in itself cannot be considered unethical or the church wouid have to close its doors. What then distinguishes what is healthfully persuasive from that which is manipulatory? Is it unethical to be trained, artful, and even shrewd in the employment of specific principles of persuasion or motivation? Is it unethical to be acquainted with the basic drives and needs of human beings, and on the basis of these to move people intentionally toward modifications in their thought or behavior? Does persuasion become manipulation when one ceases to be naive about what moves people to a desired thought or activity pattern?

The foundational sources of motivational stimuli that are particularly relevant to the matter of ethics in motivation, may be described as fear, reward, and love. These three sources are closely related to most of the needs or drives that have direct influence on human motivation. ' Although these three principles are quite interactive in everyday living, the first two (fear and reward) are especially close in relation and are more susceptible to misuse (assuming that the third principle love, is an essentially healthy love). This does not mean that using fear or reward as a means of motivating behavior is questionable per se. The realities of fear and reward are entirely natural to the human scene, and are often the only alternatives by which persons may be reached.

Jesus Himself made motivational use of both fear and reward ${ }^{2}$

1

See pp. 6-9.

'For examples of Jesus' apparent use of the fear motive appeal see Matt 11:20-24; 12:36, 37; Luke 12:8. For examples of apparent reward motive appea 1 used by Jesus see: Matt $5: 11,12$, 25 and $46 ; 7: 1,12$; Matt $15: 30-38$; Luke 12:9, 10. 
but not in a manipulative way. Although Jesus' approach was effective motivationally speaking, in that it often caused the desired behavioral change in His audience, His statements were entirely factual in nature. What Jesus did was to point to the truth of the human situation and the inevitable, even axiomatic, results of human behavior as a whole (positive reward or eternal destruction), allowing the truth itself to bring about any behavioral change. Jesus spoke the truth this way rather than using what was true (a.g., the unforgiving person will remain unforgiven [Matt 18:34, 35]) in a way that enhanced any personal goals which He might have been suspected of having. In other words, Jesus' desire to motivate was intentional and goal-directed, but he spoke the truth in such a way as to release its inherent motivational properties wi thout having to project artificial components into His persuasive systems, components that might have been introduced for His own ends. His desire was to speak only those things which His Father gave Him to speak and to consider only the truth, knowing that, as this was done, the persuasive power of that truth would itself activate the open listener. This does not, of course, explain completely the motivational effectiveness of Jesus.

It is crucial at this point to look directly at Jesus' own motivation in approaching persons with the intention of changing their ways of thinking and living. ' This is vital because it may

IPaul's motivation for his work is given with the most comprehensiveness in 2 Cor $5: 1-6,10$. It is given in answer to an apparent questioning of his motives by the Corinthian church. Notice also 2 cor $12: 13-17$. 
be inferred from the study's definition of manipulation ${ }^{7}$ that it is the motives that most clearly reveal certain approaches as being manipulative. Jesus' reason for approaching humanity as He did is given in three main statements: "I did not come to call the righteous, but sinners" (Matt 9:13, NASB). "The Son of Man is come to seek and to save that which was lost" (Matt 18:11, NASB), and "The thief comes only to steal, and kill and destroy; I come that they might have life, and might have it abundantly" (John 10:10, NASB).

There are two points that stand out in these verses as they are looked at in the light of Jesus' motivation for ministry:

1) Jesus' dealings were with those who were the sinners, the lost, the publicans, harlots, and common people. This He did in a society unlike the contemporary American culture which often rewards those who minister to the down and out. Jesus' ministry was to those through whom he was least likely to gain any personal advantage. ${ }^{2}$

2) Jesus' concentrated concern was to entiance the existence of those to whom he ministered.

John Claypool voices the ethical center of the minister's motivation when he says:

of all the questions that come to mind in relation to the preaching event, by far the most disturbing to me is the single word why? I am thinking now about the issue of motivation. What on earth is harder, really, than being totally honest at this point? When I stand up to preach.. . Why am I engaged in such effort? Am I attempting to get something

See p. 84 .

${ }^{2}$ This is not to say that other classes of people were neglected by Jesus or are to be neglected today. 
for myself or am I attempting to give something of myself. ${ }^{1}$

The thrust of this question needs to be seen not simply in terms of the minister's stance in the pulpit. This is a question which penetrates the dynamics of any person's pastoral ministry as a whole. It is definitely determinative of the kind of impact a given ministry will have upon the Christian (or non Christian) community. The achievement motivation along with that of social affiliation and self fulfillment are very relevant at this point. Achievement may we11 mean that in a'minister's pulpit ministry, for example, he must be able to "impress" his congregation or administrative superiors with artful preaching, or he will not feel he is achieving. If he does not feel he is achieving in this way he is not likely to feel accepted by his congregation, nor will he therefore feel personally fulfilled. At this point the likelihood of his becoming manipulative in his approach is heightened considerably.

Other ethically related aspects of manipulation are raised by the question of the minister's overall motivation for ministry: if a minister's achievement or social affiliation ${ }^{2}$ drives become acute enough to cause him to become manipulative, it is possible that the amount of energy expended in planning and implementing his manipulatory thought or activity could well divert him from certain important, though less recognized aspects of ministry. Secondly, in

TJohn R. Claypool, The Preaching Event (Waco, Texas: Word Books, 1980), p. 55.

${ }^{2}$ In the minister's case, social affiliation (the third level of motivation in Maslow's hierarchy of needs) would refer to the question of his acceptance with his parishioners, his peers, and to an extent, his organizational superiors. 
close relation to this, the possibility exists that a minister might, under the pressure of powerful motivations, reduce the impact of what it is his duty to say or do in a given situation. Though this modification may have certain apparently positive consequences in his life or the life of the congregation, other more ultimate considerations may be negatively affected. A third aspect related to the concept of motivation, manipulation, and ethics is the minister's attempt to use the goodness of God's saving act in Christ to promote his own ends. Here he may use the correct motivational stimuli for the wrong reason. Such a course of action would lead to the inevitable distortion of truth and have a subtle negative affect first upon the minister himself and then upon the congregation.

It must be emphasized at this point that the need-prompted motives of social affiliation, status (or esteem), and selfactualization are entirely normal, legitimate motivations without which little constructive human activity would exist. These may be related to the other motivational stimuli, namely, fear, reward, and love which are used, though non-manipulatively, in scripture to move persons to Godly thought and activity.

So far we have seen that the minister's initiating of motivational promptings in the local church may be called into question ethically when such promptings are insidiously (maybe unconsciously) used to serve the personal ends of the minister within the church organization. At this point such activity may be termed manipulatory. Such behavior is foreign to the disinterested ministry of Jesus Christ. The question now arises, How may the minister deal with the 
presence of such stimuli within himself, holding them within the bounds of the legitimate (i.e., non manipulatory) use of motivational principles in the local church? What can the minister bring to the feelings he detects in himself of competition or the compulsion to achieve?

Here the good news of God's work in Christ for humanity is crucial to the minister. Although the achievement, social affiliation, and self fulfillment need-motivations are entirely valid motivations for the minister, they need to be conditioned or brought into captivity $(2$ Cor 10:5) to higher motivations. The New Testament gospel offers a means by which this may be done. When it is seen that full achievement is already possessed in Christ through faith, that there is no barrier between God and humanity or between human and human because of the historic work of Christ (Gal 3:23-29), and that in Christ is life, wisdom, rightness, holiness, and ultimate redemption ( 1 Cor $1: 30$ ), i.e., self fulfillment, then there may be present in the minister less of a driving force and more of a drawing power, less of a compelling domination and more of an impelling dynamic for unselfish ministerial activity.

Besides this the integration of this gospel into the life of the minister gives the minister a new ideology, a new passion on the basis of which ministerial activity results. It was a grasp of the nature of the gospel which caused Paul to live gladly under a constraint which said, "Woe is me if I do not preach the gospel" (1 Cor $9: 16$, NASB) and "God forbid that I should glory, save in the cross of our Lord Jesus Christ" (Gal 6:14, KJV). Although such statements may seem to possess only homiletical force, a closer look at them 
will reveal a dynamic ideological passion which catapulted first century Christianity into virile existence. Such a motivational force tends to blunt the over-eager achievement drive; subordinating it to a much higher principle of motivation--that of simply living to share with other people the life-enhancing dynamic of the Christian gospe?.

While this gospel meets all the driving needs of the human ego, it leaves persons in the down-to-earth state of having to grapple with themselves and with daily living. The achievement, social affiliation, and self actualization needs are not removed, but are constantly conditioned by this principle. ${ }^{2}$

The Ethical Implications in Natural and Supernatural Motivation

In this section the main question is the ethical validity of the means that the minister might employ when attempting to motivate persons or groups of persons in a church setting. An important distinction is here drawn between natural and supernatural motivation. Perhaps the main point of this discussion is, however, that there should not be any separation of the two. ${ }^{3}$

By natural motivation I mean the approach which appeals to those stimuli which are significant to the practical life situation

IDonald A. McGavran and Win C. Arn, How to Grow a Church (Glendale, Ca.: G. L. Regal Books, 1973), pp. 128-132.

${ }^{2}$ See pp. $21,23-25$.

3 If the natural is subtracted from the supernatural, a meaningless and ineffective condition will result. If the supernatural is substracted from the natural, ineffectiveness will also result along with a humanistic and ul timately frustrating and unheal thy condition in the church. 
of those being appealed to. This could be correlated with what is known as extrinsic motivation. The natural dimension deals more with the efficient cause for certain behavior than the final cause ${ }^{1}$ for it. A biblical example of this is Paul's rather pointed stand in 2 Thess $3: 14$ where he urges, "If anyone does not obey our instruction in this letter, take special note of him. Do not associate with him in order that he may be ashamed. Yet do not regard him as an enemy, but warn him as a brother" (NIV). In other words, Paul here uses social pressure as a motivation for those in the church who are living idle lives (see vss. 6-13).

By supernatural motivation I mean that principle by which Christian persons are ultimately to be moved, that is, the good news of forgiving grace available in Jesus chirst. ${ }^{2}$ This may be roughly correlated with what is known as intrinsic motivation.

It is common for scripture to appeal to the natural level in human motivation. In Matt 13:49, 50 Jesus describes the "end of the age" when the angels come to separate the "wicked" from among the "righteous" to "cast them into the furnace of fire; [where] there shall be weeping and gnashing of teeth" (NASB). This language is too graphic to ignore the possibility that Jesus is here appealing to the natural fears of death, fire, and rejection. ${ }^{3}$ God's appeal to the nomadic Israelite people is also relevant, "See I am setting before you today a blessing and a curse: the blessing, if you listen

${ }^{1}$ Robert J. Austgen, Natural Motivation in the Pauline Epistles (Notre Dame, Ind.: University of Notre Dame Press, 1969), p. 39. 2 See pp. $47,42$. ${ }^{3}$ See p. 102 for other dimensions in Jesus' approach. 
to the commandments of the Lord your God, which I am commanding you today; and the curse, if you do not listen to the commandments of the Lord your God" (Deut 11:26-28, NASB). Here God seems to appeal on the one hand to an overt reward motivation ${ }^{\text {l }}$ and on the other to a fear motivation. The rewards held out are very basic to human existence; the curses that are threatened are intimately related to the common fears of the Israelite people. The rewards and fears are tied very closely to the basic needs of Israel. The reception of the blessings (reward) or the curse (fear) hinge on whether the people " 1 isten to the commandments of the Lord" (Deut $11: 27$, NASB).

Looking directly into the Pauline use of natural motivation, we see further motivational appeals. Paul's personal reasons for doing the work of Christ are quite revealing. In 1 Cor 9:16 Paul says, "For if I preach the gospel, that gives me no ground for boasting. For necessity is laid upon me. Woe to me if I do not preach the gospe1" (RSV). Here Paul alludes to the matter of reward (see also vs. 18) for his Godly activity, but he speaks also of a "necessity" as having been laid upon him. His reason for preaching is due to this necessity. He is goaded into action by it. In verses 13-15 Paul also makes it clear that his motivation is not even physical sustenance or necessity, it is the "reward" of making "the gospel free of charge" (vs. 18). Paul is saying that his motivation is not prestige or even sustenance or wages. His motivation is the "necessity" of an apparently personal commission. It is both the

IThe reward of meeting the basic needs of His (God's) people; those of safety and security, vss. 22-25, status, esteem, and power (Deut $4: 6,11: 23,24$ ). 
altruistic yet very human reward of presenting the gospel to people from whom he asks no materialistic remuneration, and also the threat (the "woe" connected to his necessity, I Cor 9:16) he feels if he does not preach the gospel.

The natural stimuli used by Paul as motivational appeals to the churches are numerous. When it came to the matter of each Christian doing his own honest labor, Paul played on the motives of personal pride, self respect, social pressure, and good appearance.' In 2 Thess 3:7, Paul appeals to his own example as a reason to work. This he does also in 1 Cor $4: 16$ and $11: 1$ as he attempts to evoke other behaviors. ${ }^{2}$

In regard to the down to earth question of Christian dress, Paul appealed to the human sense of decency, dignity, and modesty (1 Tim 2:9). Dressing extravagantly was seen to go against these sensible principles. Regarding wealth or possessions, in general Paul's motivational appeal was again on a common sense level. In 1 Tim 6:6-10, he shows that wealth is limited only to this elusive world and this temporary existence (vs. 7); that the desire for riches is hurtful and leads to ruin (vs. 9); and that great unhappiness and anxiety ("many panys" $1 / 5$. 10, RSV) may result from the love of money. Paul's appeal in this instance is not to the grace of God, the poverty of Christ, or even the spiritual corruption often accompanying riches. Paul rather appeals to the human ruin, the anxiety and unhappiness that is often the lot of the rich.

${ }^{1}$ Gal $6: 4,5 ; 1$ Thess $4: 12 ; 2$ Thess $3: 7-11$.

${ }^{2}$ Notice Paut's similar appeal to the Ephesian elders in Acts $20: 17-35$. 
In motivating the church to civic responsibility (1 Tim 2: 1-7), Paul did not appeal only to a supernatural, religious motive. Instead, he appealed also to aspects of life that were very real to those to whom he was writing. Did not the Christian community wish to lead "a quiet and peaceful life"? (1 Tim 2:2, RSV). Then a certain cooperation was necessary.

In this connection Robert Austgen sees Paul making motivational use of popular norms of social conduct, generally prevalent in the Greco-Roman world of the Christian community:

Homonoia stood as one of the noble aspirations of the GrecoRoman world. The absence of "like-mindedness" in any religious group brought immediate suspicion upon it. This... was a potent social pressure urging the Christian Community to conform to the social norms of the day. The impression of outsiders was an important consideration in the early apostolic church (Col $4: 4 ; 1$ Thess $4: 5) .^{2}$

Paul's motivational approach was obviously highly adaptive, appealing to a wide range of human incentives. Paul seems to have realized, probably intuitively, that the motivational spectrum of the average human being is multi-dimensional, quite complex, and dynamic. Paul was definitely "all things to all men" (1 Cor 9:12, KJV) in the field of motivation, and it is interesting to note he takes this stance in order that he might "win" (vss. 19, 20, 21, NIV) or persuade some. ${ }^{3}$

This passage (1 Tim 2:1-7) shows an interesting blend of motive appeals--religious and non-religious, natural and supernatural together.

${ }^{2}$ Austgen, p. 119.

${ }^{3}$ The word that is translated as "gain" in the KJV is the word

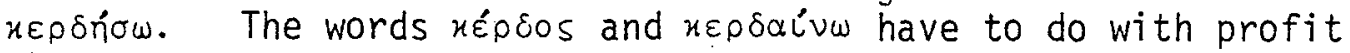
through craft or cunning. Although I feel that craft and cunning per 
What now of the biblical use of supernatural motivations?

In the asking of this question, the issue of the ethics of motivation comes strongly into play. On the basis of that which is normative for this paper (namely, the supernatural motive force of the pardoning love of God as revealed especially in the New Testament gospel), how can it be said that the biblical appeals, made, for example, by Paul as noted above, are non-manipulative and ethically sound? In other words, how do supernatural motivational stimuli validate the natural stimuli?

An answer begins with the fact that in almost all of the instances of the biblical use of natural motivation, supernatural realities are in the immediate or near to immediate context. This may be observed in the examples of natural motivation referred to above.

In Matt 13:49, 50, Jesus' strong words concerning the final separation (vs. 49) are spoken in parabolic terms, and following two parables that deal with a treasure hidden in a field (vs. 44) and a pearl of great value (vss. 44,46$)$. The implication is that the possession of the spiritual treasure, or the "supernatural" pearl, precludes the horror of the separation and the fire of verse 50 .

In the 01d Testament example of natural motivation cited above from Deut $11 ; 26-28$, supernatural motivation appeals are very strong in the preceding verses. In Deut 11:1-7 the great acts of God in delivering Israel are rehearsed. Verse 8 then begins, "You shall

se have no placein Christian motivation (for such efforts easily become manipulatory), the use that Paul seems to put such an approach to, and the reasons for which it is done, seem entirely appropriate. 
therefore keep all the commandments which I command you this day" (RSV, emphasis supplied.) Verse 18 begins similarly. Only after the supernatural reason for obedience is clearly delineated are the consequences of disobedience candidiy spelled out in terms that are naturally motivating in verses 26-28.

In the Pauline use of natural motivation the same supernatural-natural motivational construct is quite clearly presented. An overall case for this can be made on the basis of the way that Paul constructed most of his main epistles. Romans, Galatians, Ephesians, Phillippians, and Colossians are good examples. Each of these Epistles may be roughly divided into two parts. In each of the above mentioned Epistles, Paul first presents the spiritual or supernatural aspects of his teaching. In the second portion he presents his moral or ethical teaching. Paul's great reason for Godly activity such as missionary work and moral circumspection is the good news of pardon and salvation in Jesus Christ. This may be quickly seen by observing the overpowering evidence that it is this gospel which is Paul's passion. On account of the gospel which he defends, for which he is stoned, imprisoned, and finally executed, Paul goes to the ends of the earth. The natural appeals of Paul in his Epistle are never far removed from the supernatural.

Paul clearly wishes to move the churches from a mere susceptibility to natural stimuli, to a deep spiritual commitment that is a strong governing force in the life of the community. With Paul there is a clear path of communication or continuity, heavily travelled, between the supernatural and the natural. This may be most easily seen in Paul's use of the word "therefore." In Rom 
$6: 12 \mathrm{ff}$, Paul pleads for sin to be disallowed its reign on the basis of the doing and dying of Christ; "Let not sin therefore . . ." (KJV). Romans 12:1 is a further example of this, perhaps the best. Here the word "therefore" is used connecting Paul's spiritual teaching with his moral appeal. In this sense it is a pivotal word in this epistle. Paul moves deftiy from the climactic doxology of chapter 11:33-38 and a 11 that has preceded it to the down-to-earth reality of sacrificial living. The two are clearly connected in Paul's mind.

Paul goes further than this: his Christianity and his motivational appeal were highly practical. Paul met people at the level of their most potential response, though he did not capitalize upon this in an under-handed way. Though Paul understood the social, cultural, and psychological dynamics of his day and his people he did not use these principles manipulatively, but rather in a common sense way, always overshadowing them with the great supernatural reality of the pardoning love of God revealed in the liberating acts of Jesus Christ.

It would seem that that which kept Paul's natural motivational appeals ethically sound was 1) the motive behind his appeal: that of bringing "more abundant" life to the community through the gospel; 2) the fact that his natural appeals were not divorced from a genuine appeal to supernatural stimuli, i.e., "his" gospel.

It may be concluded that natural and supernatural motivations need to be held together in a healthy strategic relationship. In order to reach people at the level of their most likely response, natural appeals are totally in order. The fact that these levels 
have not been generally distinguished and employed by the pastor may well account for some of the frustrating lack of activity that is often felt in contemporary churches. On the other hand a faiture to communicate by scripture and the Holy Spirit the splendid news of the pardoning love of God in Christ and its ability to reach all the levels of humanity's need, may account for the failure and frustration felt when natural motivational appeals are made and little response (especially of an enduring nature) in the Christian community is forthcoming. Furthermore, when these two are intelligently combined, the question of an ethical use of motivational stimuli may become less urgent. 
CHAPTER II

\section{MOTIVATION AND THE SPIRITUAL DIMENSION}

This chapter will begin by discussing the needs and motivational stimuli of the local Christian community from a spiritual perspective. It will then attempt to show how these needs might be dealt with through the worship and preaching ministry of the church and how this might affect the motivational dynamics of the church conmunity. The nurture and care of the congregation will be approached similariy. The overarching principle of this study-the pardoning love of Christ shown in the Christian gospel--will condition the overall discussion. The motivation of the local church to Christian witness will underlie much of what is discussed.

The Spiritual Needs of the Christian Community

Donald McGavran has spoken carefully about the proverbial "Rice Christian":

As the Gospel is proclaimed, men sometimes seek to become Christians from unworthy motives. . . Every churchman does well to beware of such men.

On the other hand, he who proclaims the Good News and welcomes men to salvation must also beware lest his suspicions [concerning a person's motiyes] deter those who are groping their way toward salvation.

TDonald McGavran, Understanding Church Growth (Grand Rapids, Mi.: William B. Eerdmans Publishing Company, 1970), p. 150. (Parenthetical statement added.) 
Improper motives for becoming or remaining Christian are not the exclusive property of India or China. Jesus chose twelve men whose motives for following Him included the hope that he would drive out the Romans, restoring Israel's autonomy (Acts 1:6). Many others followed Jesus because of his ability to heal. With only one exception, in all the accounts in Matthew which speak of crowds following Jesus, healing is clearly the primary motivation for their following him. ${ }^{1}$ Further, it may be noted that in 211 of these accounts, Jesus gladly healed the sick. There is no hint of His questioning their motivation, though it is certain that He wished to draw them toward more satisfying sources of motivation. Further, it must be noted that in each of these instances and in others, Jesus skillfully built on to the very understandable yet questionable motivation and action of the people of His day. He moved artfully from their less-thanideal motivation and action to higher things, using their thinking and action as a point of beginning.

In at least one instance (John 6:26-66), however, Jesus did question the motivation of those who came to $\mathrm{Him}$, but He did it in such a way as to hold before them a higher motive. When they came to Him because He had fed them, He pointed them to Himself as the bread that had come down from heaven (vs. 32). Here Jesus is seen as taking advantage of natural, down to earth motivations (hunger and curiosity), calling these into question (vs. 26) and presenting the supernatural motivation of his gospel, even though this ultimately

${ }^{1}$ See in context Matt $4: 25 ; 5: 1 ; 12: 15114: 13$; and $19: 2$. Matthew 21:9 is the account of the triumphal entry and even here the motives of the crowds could have been severely questioned; yet Jesus allows it to happen as they wished. 
cost him "many" of his disciples (vss. 58-66). Jesus' approach to the woman at the well was similar (John 4). (When it came to the motivation and action of the Jewish leadership however, Jesus was forthright [Matt $6: 1-6 ; 23: 1-33])$.

This point must be brought into focus. The church may be filled with people whose perceptions of their needs are not necessarily as "spiritual" as might be wished, and therefore whose motivations might be questionable. The skilled minister takes these people on the level where they are most likely to be responsive. He carefully capitalizes on this, and then holds before them a more elevated, all inclusive motivation: gratitude for the good news of the pardon of God through the historic activity of His Son, Jesus Christ. The more natural motives of people are based upon real and valid needs, which must be recognized and met so that higher motivations may be released. ' Even the most mature Christian, simply because of his common humanity, may find a wide variety of motivational dynamics consistently at play within himself. As Robert Austgen has said:

The average person in everyday life does not make these technical qualifications. Motivation for him is a multidimensional phenomenon. His moral ideals in life actually represent a configuration of many submotives. ${ }^{2}$

Although people join themselves to the church because of a rather intricate complex of needs and motivations, it is important to see, once they are in the church, what some of their crucial

\footnotetext{
pp. 6-8.

'This is foundational to Abraham Maslow's thinking. See ${ }^{2}$ Austgen, p. 4.
} 
spiritual needs are. Some of these needs may have been part of a person for years; others may have arisen because of experiences, positive or negative, within the church. For the sake of brevity only those needs arising out of feelings of guilt will be discussed here.

The need for guilt resolution is crucial to many within the Christian church. Bruce Narramore describes the inadequate extent to which the church has acted in dealing with this underlying problem.' Narramore speaks also of the crucial role guilt plays in both the psychotherapeutic process and the Christian experience. He sees guilt as manifesting itself in an acute sense of worthlessness and depression; in obsessions and compulsions, or simply in pangs of guilt. The church, however, instead of acting as a catalyst for guilt reduction has often unwittingly adopted motivational strategies which capitalize on guilt feelings thus increasing the load of guilt. ${ }^{2}$ The feeling of "pain" that accompanies guilt does indeed engender strong motivational energy that may be directed into areas of constructive activity that supposedly ease such feelings. But persons whose guilt is largely assuaged through the possession of a genuine sense of God's free pardon, are likely to be motivated more deeply and positively and with more personal satisfaction by more healthy and positive stimuli.

The need for guilt resolution in the church may be put in

1Bruce Narramore, "Guilt: Where Theology and Psychology Meet," Journal of Psychology and Theology (Winter, 1974): 18.

${ }^{2}$ Narramore, "Guilt: Christian Motivation or Meurotic Masochism?" Journal of Psychology and Theology (Summer, 1974): 182. 
more specific terms. David Seamonds speaks of "the tyranny of the ought," the feeling of self depreciation, anger, denial, and anxiety that are present especially in those whose thinking leans in the direction of what he calls "perfectionism." In a very insightful description, Seamonds says,

The perfectionist with his oversensitive conscience, his low self esteem, and false sense of guilt, is naturally very sensitive to what other people think about Him. Since he does not like himself, does not approve of himself, and is quite unsure of God's approval, he desperately needs the approval of other people. . . . He is easy prey to the opinions of other Christians. All the while the do's and don'ts are piling up, because more and more people have to be pleased. His halo has to be adjusted for this person, and readjusted for that one. He keeps fitting in this way and that way, and before he realizes what is happening, his halo has become what Paul called "a yoke of bondage" (Gal 5:1). ${ }^{2}$

In this statement Seamonds isolates a number of crucial and common needs in the christian community. These might be delineated as: a more mature conscience, ${ }^{3}$ higher self esteem, a proper sense of guilt ${ }^{4}$

IDavid A. Seamonds, "Perfectionism: Fraught with Fruits of Self Destruction," Christianity Today, Apri1 10, 1981, pp. 24, 25.

${ }^{2}$ Ibid., p. 25.

3 By "mature conscience," I mean a conscience that is aware of how to deal constructively with guilt, not becoming unduly depressed or distressed over failures. The mature conscience knows where to take guilt, while at the same time it realizes the reality of failure and the need for improvement.

${ }^{4}$ Paul Tournier, Guilt and Grace (New York: Harper and Row, Publisher, 1962), pp. 17-24, speaks of true and false guilt. He sees false guilt as growing largely out of the tyranny of social expectancies (the guilt of the illegitimate child or the genuineiy ill person who cannot work etc.). False guilt seems to stem generally from narrow human traditions and the inability of the conscientious person to live up to these.

The Bible does, of course, speak of "Godly sorrow" (2 Cor 7:8-10) and "repentance" (Rom 2:4) and "confession" (1 John 1:9). But it always seems to place the human in a position of legal guilt rather than "psychological guilt" (Narramore, p. 184). In Scripture, guilt is dealt with primarily in terms of being objectively liable 
and a sense of freedom from the judgments of the "oughts" and the "ought-nots."

Besides these needs, others become apparent due to their close relation to those listed above. Joseph $R$. Cooke lucidly exposes at least one foundational need as he writes autobiographically. He speaks of his invention of a God impossible to please. Though he believed in grace and even taught it, his real feelings were not consistent with his belief. To him God was always frowning, with high demands for cooke and, at the same time, a low opinion of him. "A11 day he nagged me," says Cooke.

Why don't you pray more? Why don't you witness more? When will you ever learn self discipline? How can you allow yourself to indulge such wicked thoughts? Do this, Don't do that. . . God was always using his love against me. He'd show me his nail pierced hands, and then he'd look at me glaringly and say, "Well, Why aren't you a better Christian?" . . When I came down to it, there was scarcely a word, or a feeling, or a thought, or a decision of mine that God really liked.

in judgment, rather than in the highly blaming, emotional terms of a personal, psychological shame. This does not in the least attempt to remove culpability before God, but it removes the aspects of personal rejection and emotional exclusion from the guilt that the Christian might feel.

Elizabeth Hurlock, Development Psychology: A Life Span Approach (New York: McGraw-Hi71 Book Company, 1980), p. 177, in citing $H$. J. Eysench, draws a distinction between guilt and shame. Guilt is seen as a "special kind of negative self-evaluation that occurs when an individual acknowledges that his behavior is at variance with a given moral value to which he feels obligated to conform." In contrast, shame is an "unpleasant emotional reaction of an individual to an actual or presumed negative judgment of himself by others, resulting in self-depreciation vis-a-vis the group." Shame thus arises solely out of external sanctions and may be accompanied by guilt. On the other hand guilt arises out of both internal and external sanctions. It is the unpleasant emotional feelings associated especially with shame that the church cannot allow itself to be occupied as a motivational stimulus.

Joseph R. Cooke, Free for the Taking cited by David A. Seamonds, "Perfectionism: Fraught with Fruits of Self Destruction," p. 26. 
Stating it simply, perhaps the greatest need in the church, conveying the most profound implications for Christian motivation, is the need to truly love God in view of His forgiving grace. Such love cannot be legislated, especially when it is largely because of a legislative attitude, often prevalent, that people find it so hard to love God (especially Cooke's demanding, almost sadistic god). As the true nature of God and His saving work is exposed (John 3:14; 12:32) people come to love God and begin to find their needs met while a new reason for action emerges.

For example, it is quite understandable that normal persons would have very mixed feelings about "presenting their bodies a living sacrifice" (Rom 12:1, KJV) to the kind of god described by Joseph Cooke. It is with this sort of god in mind, however, that surrender is sometimes called for in evangelistic crusades and in the weekly worship service. On the other hand, when "submission" is called for on the basis of "the mercies of God" (Rom 12:1, KJV), when those mercies are authentically portrayed in the psychospiritual needs of man (as they are in the scriptural passages preceding Rom 12:1), then, through the convincing work of the Holy Spirit, the average person will be more likely to be motivated to do just what is called for in such a submission.

It seems evident that the actual nature of the gospel is crucial to the motivating of human beings in general and christian persons in particular. If the pardoning "mercies of God" are presented as genuinely free in Christ through faith (Eph 2:7-10), if the historical work of Christ is set forth as a finished work, totally adequate for the full acceptance of humanity by faith (Rom 5:15-19), 
then the merciful forgiving grace of God may be grasped. The resulting love and gratitude will evoke Godly activity.

When human beings realize the extent of their dilemma, ${ }^{1}$ the profoundness of their separation from God and from life, and thus the immense love and mercy extended to them in Christ, they are moved to constructive action. It was evidently this that Jesus had in mind when He said to the adulterous woman, "Neither do I condemn thee: go and sin no more" (John $8: 11$, KJV). Godly activity and genuinely Christian behavior is called forth by the realization of the free forgiveness of God. The removal or reduction of guilt opens the way for higher, more provocative motivations to loving, constructive action.

Motivation of the Congregation

in Worship and Preaching

James L. Christensen has said,

Gratitude is the very matrix of the Christian's heart. It is the precondition to worship. It is out of a conscious dependence upon God and a recognition of His undeserved goodness to us that we ask, as did the Psalmist: "What shall I render to the Lord for all his bounty to me?" (Psalms 116:12). This is life's most penetrating question. The spiritually sensitive person answers with worship and all it entails.?

That Christians come with multidimensional configurations of needs, expectations, and motivations, is no less true in the area of corporate worship than in any other area of life. Many come hoping to find emotional healing. Others may come merely to still a troubled conscience. One of the most commonly stated motivations for

\section{See pp. 16-20.}

2 James L. Christensen, Don't Waste Your Time in Worship (01d Tappan, N.J.: Fleming H. P.eve17, 1978), p. 48. 
attending community worship is, "to get a blessing." This mentality reflects a worship expectancy that is directed almost exclusively at the worshipper's needs. It finds difficulty discovering any greater need or motivation higher than self fulfillment. It tends to be preoccupied merely with what happens within the experience of the worshipper. For this reason such worship seems to be susceptible to a rather unhealthy entertainment orientation, in which God appears to be used as the rallying point for good feelings (i.e., blessings"). Is it then too idealistic to agree with Christensen, that gratitude is the matrix of the Christian heart and the precondition (i.e., motive) for worship? Or that, "Worship is man's loving response to God's personal revelation in Jesus Christ?"1

On the basis of what has been said in the previous section of this chapter, it must quickly be affirmed that condemnation of lesser motives for worship is definitely out of place. It should be further affirmed, consistent with the general tenor of this paper, that the basic needs of the Christian person must be addressed in worship or it will be meaningless. It is also affirmed however, that higher motives for worship should be sought for and appealed to in the corporate setting of worship, leading to a more heal thy worship experience.

Franklin Segler has listed ten human needs that are present at worship: a sense of completeness, the need for understanding, security, companionship, belongingness, forgiveness, peace, purpose,

I Ibid., p. 30. 
healing, and comfort. 'These needs generaliy reflect those presented in Maslow's hierarchy of needs. This suggests that these needs are critical to human motivation. If these needs are true to the cry of the human soul, every local worship committee must take them seriously when forms of worship are being planned. A worship service that creatively gears its forms to speak to and meet these needs is going to motivate those present in worship to become a part and remain a part of such a congregation in worship. It is important that the meeting of these needs become a part of the goals of an intentionalized worship service.

The biblical model of worship, however, seems to call for a type of worship that does more than merely drawing in. ${ }^{2}$ It also calls for an activity which impels outward movement. Bringing this about evidently calls for exposure to a different level or dimension of motivation. Moses' experience at the burning bush (Exod 3), Isaiah's in the temple (Isa 6), and Paul's on the Damascus road (Acts 9), though they did not involve corporate worship experiences, were yet encounters with God in which these men, awed by the magnificance of God, heard the call of God to service. Their service moved beyond theoretical sermonizing to a radical, down to earth meeting of human needs in God's name.

1Franklin M. Segler, Christian Worship It's Theology and Practice (Nashville: Broadman Press, 1967), pp. 83-86.

${ }^{2}$ That is, that keeps faithfut church members coming to congregational worship week by week. 
David Randolph comments on worship that he terms "sensitively missiona?": 1

Worship that merely catalogs heart failures, however, is not truiy Christian worship. That is, liturgy that simply recites aspects of human tragedy [i.e., that speaks only to common human needs] is as faulty as liturgy that seeks to ignore them. What is called for is the creative approach which sees in the troubled situations of the world an opportunity to serve one's brother. Genuinely missional worship is distinguished from immature and irresponsible social commentary precisely in the way in which it opens up opportunities for people of God to accept responsibility for the world. 2

But how is such a missional worship brought about? The minister along with the worship committee could easily construct a worship service whose theme is mission. This has been done. But the question is, How may such worship actually be evocative of a genuinely productive mission? How may more than the usual few become involved in more than a partial missional sensitivity and activity? Although to claim complete answers to this question would be presumptuous, some suggestions are in order:

1. The release of genuine missional concern within the Christian is intimately related to the fundamental matter of love for God and other persons. When Christians are yet concerned with the elemental questions of their own salvation, their own needs and insecurities, it is impossible for them to be genuinely missional. It may be presumed that the outreach activity they do participate in is done to win God's approval or that of their fellow Christians. It is imperative therefore that Christians be freed from the tyranny of

TDavid James Randolph; God's Party: A Guide to New Forms of Worship (Nashville: Abingdon Press, 1975), p. 56.

$$
{ }^{2} \text { Ibid., p. } 57 \text { (parenthesis added). }
$$


these needs. ${ }^{1}$ As the pardoning acceptance of God in Christ is experienced in the Christian community, human insecurity, guilt, and inadequacy are replaced by a liberation to worship and serve.

In Exod 5:1, Moses speaks for God, "Let my people go that they may hold a festival to me in the desert" (NIV). It was impossible for Israel significantly to worship or to follow the leading of Yahweh into service as long as they remained in bondage. Anyone attempting to motivate Israel to worship and Godly service before this liberation would have been highly frustrated himself, as well as frustrating to Israel as a whole. In other words, this liberation must be a reality in the life of the Christian before other motivational stimuli can become properly effective. It seems futile to deal with Christian mission in worship while this need in the church remains largely unmet or is taken for granted as having been met or is more or less neglected.

2. Christian worship is often spoken of in terms of celebration. $^{2}$ In Exod 5:1 God is represented as speaking in terms of a "festival" (NIV), celebration (NASB), or feasting (RSV, KJV). Here worship is actually being spoken of (see vss. 2, 3). This sort of celebration cannot properly be created by the artful selection of a certaindecor and certain songs, or by an atmosphere of informality.

${ }^{1}$ Again these needs seem to be especially the need for basic guilt resolution, for a certain freedom from insecurity before God, for freedom from the tyranny of the "oughts" and "ought-nots," for a positive sense of acceptance and wholeness as a person in Christ.

2The very title of Randolph's book, God's Party, is indicative and somewhat representative of the celebration terms in which contemporary worship is spoken of. 
Celebration, by common understanding, involves the commemoration of something specific. A feast or festival is held in honor of some particular occasion or person. When the original cause for celebration is clouded in the minds of the celebrants, the reason for the existence of the festal activity and atmosphere becomes proportionately blurred. As a result, the motive energy present in the rehearsing of the great deeds of the past is not generally present. Thus a decline in behavior responsive to that which is being celebrated, may also be expected. The joyful climate which generally accompanies such celebration and which tends to be motivational in itself is also generally missing, or becomes something contrived or imposed upon the situation.

More positively, when the great deeds of God in the past in behalf of His people, specifically the central Christ event, are truly held at the core of Christian worship, these events and all they brought in for humanity provide a reason for weekly rehearsal and celebration. They serve in turn as a potent motivational force for the Christian community.

When Christian worship ceases to revolve around the acts of God it ceases to be celebrative, and its motivational impetus understandably declines. As this occurs, a more legislative atmosphere results, as the community and its leaders attempt to bolster the receding climate of joy, celebration, and Godly, missional activity. Flowing out of this sequence, a preoccupation with what "ought" to be 
in the Christian community ${ }^{7}$ supplants the celebrated splendor of what "is" because of christ. Thus the community tends to be motivated more on the level of compulsion than on the more desirable level of that which might be carefully described as impelling. In short, the burden of this approach is that the acts of God, especially through His Son Jesus, be intentionally and intelligently placed at the core of Christian worship. Grasping this principle, the local church should carefully work out its own liturgy.

In moving to the issue of Christian preaching, it may first be said that it is traditional for Protestantism and for the Seventh-day Adventist church to place the preaching event in a more or less central position in the act of weekly worship. P. T. Forsyth ventures that Christianity stands or falls with its preaching. In the same context Forsyth draws a very striking distinction.

Preaching... is quite different from oratory. The pulpit is another place... from the platform. The Christian preacher is not the successor of the Greek orator, but of the Hebrew prophet. The orator comes with but an inspiration, the prophet comes with revelation. . . Where your object is to secure your audience, rather than your Gospel, preaching is sure to offer. . . . It is one thing to have to rouse or persuade people to do something, to put themselves into something; it is another to have to induce them to trust somebody and renounce themselves for him. ${ }^{2}$

Forsyth insists that the orator must be distinguished from the Christian preacher in that the orator is merely intent on getting people to do certain things. The orator's objective is to cause people to

The remainder is again appropriate here that the "ought" motivation per se is definitely not negated in this study, but that the "ought" motivation without the "is" motivation is definitely questioned.

${ }^{2} p$. T. Forsyth, Positive Preaching and the Modern Mind (New York: Eaton and Mains, n.d.), pp. 3, 4. 
behave or act in a given manner. The goal of the Christian preacher is different. His attempt is to bring about or strengthen a relationship of trust in God on man's part. The aim of the minister is to effectively announce the reconciliation (2 Cor 5:20) of humanity to God that has occurred in Christ so that humanity may by faith avail itself of this. As this occurs God Himself activates or motivates the human will by His Son and Holy Spirit through the good news of his pardoning grace. Thus, the hoped for changes in behavior and action begin to occur and become progressively mature as the relationship with God continues.

Other considerations must be placed alongside Forsyth's assertion. Preaching, like worship, must speak to the down-to-earth daily drama of the lives which it addresses. The greatest challenge to the preacher is to bring the gospel to bear upon the needs of the congregation, while these needs are genuinely understood and used as avenues of communication and motivation in the congregation. Preaching, though it may be gripping and oratorically irresistible, will do little more than draw a good audience unless the New Testament gospel is brought to bear on the needs, desires, and fears of people. On the other hand, when the good news of God's pardon in Christ is integratively grasped, it tends to meet these needs and desires in persons. By its nature it rouses and stirs those persons, creating in them an ongoing desire, even need, to tell its good news to those who will listen. It also moves them to behave in a way consistent with the One by whose rightness they now live.

In actually applying some of the principles of human motivation in Christian preaching, the following suggestions may be 
heipful: a series of evangelistic sermons might be composed around the basic needs of human beings as delineated by Segler. ${ }^{1}$ This could be done in such a way as to show the needs of persons as growing out of the dilemma of humanity. Such needs are dramatized by the requirements of God's law, and they may be proclaimed as having been met in the person and work of Jesus. Prepared carefully, such a series would tend to hold attention more effectively, while moving persons out of the sphere of preoccupation with unresolved need and into a more mature, positive, selfless, and serving sphere. The distinctive truths of Adventism could be fitted into such a scheme.

In a series of sermons on Christian stewardship, for example, the pastor could carefully appeal to a broad spectrum of motivational stimuli, both natural and supernatural. ${ }^{2}$ One could, for example, appeal to:

1. The oneness in the community of believers and the obvious need for a shared responsibility for support within any body of people

2. Self-respect; each member doing that which it is his part to do

3. The sense of accomplishment, of personal satisfaction derived when such participation occurs

4. Honesty with God and one another in the way we respond to felt needs

5. The specific items for which financial assistance is needed. (Not generalized, appeal oriented needs; but rahter, the

${ }^{1}$ See pp. 108, 109. $\quad{ }^{2}$ See pp. 91-99. 
the "believers-in-Jerusalem" kind of description. I cor 16:1-3.)

6. A projected sense of pride in that which the money, time, or talent brings about

7. The satisfaction of having something representative before the world at large, comparable to the standards which other organizations have made normative.

Over-shadowing all of these should be a carefully thought out, fresh articulation of the stewardship of Jesus Christ, including the aspects of the nature and extent of His sacrifice and its accomplishments. Passages of Scripture such as Phil 2:4-11 may be helpful here.

A careful weaving of natural and supernatural motivational stimuli should be most effective, and also most likely to preserve a non-manipulative approach to Christian preaching.

Motivation in the Care and Nurture of the Congregation

Chevis F. Horne, writing on Christian counseling, has said, God's acceptance of us in grace has posed a serious moral problem for some. This seems to cut the moral nerve. Since God so graciously and freely accepts us, why worry about moral achievement? He accepts us anyway. But this is to misunderstand the ethical implications of God's grace. It turns out that God's acceptance of us becomes the highest ethical motivation. The accepted person wants to live a life consistent with the new status God has given him in grace. He strives to live the good life not in order to win God's favor, but because God has freely given his favor.

Horne hits directly upon the central principle of this

${ }^{1}$ Chevis F. Horne, "A Theology of Counseling," Pastoral Psychology 19 (November, 1968): 32 . 
study. ${ }^{1}$ He goes on to say that the manner in which God accepts persons in grace should be reflected by the Christian minister in the way he speaks to those who approach him for counsel. When a person realizes that his counselor understands and "has accepted him, this becomes the strongest possible motivation to become the kind of person his counselor believes he can be and the kind of person he himself really wants to become. ${ }^{2}$ It may often be unwise for the Christian counselor to speak to the counselee in religious language. The operation of grace may rather be mediated to the counselee in profound terms as the minister himself acts with open acceptance toward the counselee in the same way that God has acted and continues to act toward him as a struggling human being.

Although Carl Rogers does not express himself in religious terms, his assessment of the human scene, and specifically his assessment of human need and thus of motivating behavioral change in the counseling setting, may be correlated with the principle expressed above by Horne. Walter Mischel says that

Rogers (1959) assumes a universal need for positive regard. ... This need leads the person to desire acceptance and love from the important people in his life. The person needs positive regard not only from others, but also from his self. The need for self-regard develops out of self-experiences associated with the satisfaction or frustration of the need for positive regard. If a person experiences only

'Far from opening the doors of Christian circumspection to passion and permissiveness, the unconditional accepting pardon of God, when properly understood, will have exactly the opposite effect. There are always those who will seem to prove this principle to be erroneous, but there are also those whose lives indicate the opposite.

2 Ibid., p. 32. 
unconditional positive regard, his self regard also would be unconditiona?. 1

If Horne and Rogers are correct, every person (or almost every person) who comes to a counselor for help, has, aside from other needs, the need to experience acceptance or positive regard. This need may become even more acute as counselees make themselves vulnerable to the counselor by sharing problems or feelings which they may feel ashamed of. This is likely to be especially so when a minister is the counselor and when, for example, the counselee expresses homosexual tendencies.

I would maintain that under such circumstances it wouid be difficult for many Christian counselors (even though they may know they should) to project a sufficiently potent sense of genuine positive regard or acceptance for such a counselee, without the existential realization and implementation of the principles of the Christian gospel in the counselor's (minister's) own life.

The commission of Christ is not merely to love one another, but to "love one another, even as I have loved you". (John 13:34, NASB). The application of this specific quality or kind of love is that which heals and motivates. This healing and motivation occurs because through the acceptance and positive regard of the counselor, the counselee tends to be released, through satisfaction, from the

Walter Mischel, Introduction to Personality (New York: Holt, Rinehart and Winston, 1971), p. 95. 
driving need for positive regard and unconditional acceptance.

In other words, in order for healing to take place, even al though the gospel cannot be overtly presented in many counseling situations, the counselor needs to personify the gospel rather than the law $^{2}$ in the way he relates to troubled persons especially. That is to say, that even although the counselee may need firmness and a sense of direction, the counselor will tend to be more constructively motivating if his approach is noe of genuine positive regard for the counselee.

This ability to accept persons where they are is foundational to the Christian gospel. 3 When a counselor holds himself in some way to be superior, when he is even inadvertently judgmental, the counselee is afraid to share his real problem. It is natural for him in such circumstances to attempt to conceal what is his real

'Consistent with the theological stance of this study, "unconditional acceptance" does not mean a permissive "anything-goes" kind of attitude with no desire to move a person to more satisfying planes of Godly activity. Rather it means that the minister views all persons, in this case, counselees, in terms of the cross of Christ, i.e., in terms of God's view of them because of Christ. This is especially applicable in the case of Christian counselees who are assumed to be "in Christ," brothers or sisters in the most significant sense.

2 "Personifying the gospel" definitely does not mean ignoring the law. Fundamental attitudes are here referred to. It may be healthy for the Christian church to assume that despite its many compromises of the holy law of God, it yet has trouble in that it often represents itself within its own community and to the world more in "Mosaic" than Christian terms. It is interesting to note that to struggling sinners who realized their guilt, Jesus generally presented the balm of the gospel (John $8: 1-11$ ) but to those who needed to realize their inadequacy, Jesus presented the law (Luke 18:18-22).

${ }^{3}$ See Luke 15:1, 2; Rom $5: 7,8$; Deut $7: 7,3$. 
concern lest he be hurt by the judgment of this person (the ministercounselor) who is significant in his life.

At this point it is important to reinforce the fact that a definite reason for Christian counseling is to bring about changes in thought, attitude, and behavior with the law of God in mind. The crucial question, however, is by what means such change is affected. The point of the foregoing discussion is that healthy, enduring change is far more likely to occur in an atmosphere of unconditional positive regard and acceptance. This, however, because of the high concern for ethical standards of conduct, seems difficult to achieve in the church, even though it is known widely to be urgently needed in the community of faith. Internalizing the fact that God for Christ's sake has fully accepted the Christian counselor himself will go far in alleviating the reaction of non acceptance that may arise, even unbidden, in the counselor as he confronts many situations. For the secular counselor, with generally fewer and less personal ethical concerns, a certain kind of counselee acceptance is attainable. For the conscientious, concerned Christian counselor, however, a radical principle, growing out of a dynamic acceptance of the New Testament gospel, is imperative to a healing, truly therapeutic relationship between the Christian counseior and counselee.

In moving to a more communal perspective in the care and nurture of the local congregation, Howard J. Clinebell is helpful. He asks some questions relevant to the psychospiritual health of the

${ }^{1}$ See Roger's view, p. 119, particularly his reference to "the important people" in a person's life. 
local congregation. ${ }^{1}$ These questions have definite motivational overtones. One is, "Does a particular form of religious thought and practice build bridges or barriers between people?" It may be clear at this juncture in the study that "bridges" between people could be highly productive of a good motivational climate, while barriers between people could act as barriers to dynamic motivation.

Clinebell asks further, "Does a particular form of religious thought and practice provide effective or faulty means of helping persons to move from guilt to forgiveness? Does it provide welldefined, significant, ethical guidelines, or does it emphasize ethical trivia? The attempt in this paper so far has been to show the overall relation between a Christian approach to motivation and the resolution of guilt in the finding of forgiveness. The evidence seems to point to the fact that guilt resolution and a well based sense of forgiveness is fundamental to the effective motivation of the Christian. Unhealthy preoccupation with "ethical trivia" may provide the Christian with roadblocks to guilt resolution. A person may find it difficult to be motivated to selfless service while engrossed in the matter of his or her own guilt.

Clinebell finally asks, "Does a particular form of religious thought and practice strengthen or weaken self esteem?" Self esteem is basic to motivation for the Christian. A certain resolution of that need is required if constructive activity is to continue to take place. When the self esteem of an individual is under fire, as

1Howard J. Clinebel], Mental Health Through Christian Community (Nashville: Abingdon Press, 1965), pp. 30-54. 
occurs in some church settings, much of the motivation for supporting that church and its ministry may well be lacking or may be existent just for the cause of finding a reason for self esteem. On the other hand, when in a given church setting, the self esteem need is adequately dealt with through the manifestation of a Christ-based acceptance of one person by another, there is more reason for highty motivated activity.

Looking still further into the communal life of the church, we observe that as the church as a whole becomes existentially aware of its identity as defined by the good news of God's pardoning grace in Jesus, it will tend to become a more merciful, caring, nurturing, and accepting community. It will be more open to genuine expressions of positive regard within itself. This kind of acceptance also tends to reproduce itself. As the community sees itself as entirely right through the completed work of Jesus for each individual in it, the community is free to minister more fully to its internal needs and the needs of the world community. Possessing the full esteem of God because of Christ through faith, individuals within such a community are free to esteem one another highly and unconditionally. As they looked through eyes of mercy, reflecting those of God in his pardoning love for them through Christ, they could afford simply to love one another in a genuine and practical way while together they served the world.

A.though this view of the church and such a description of it as a place of care and nurture may seem highly idealistic, its reality may be far more within the reach than is often thought possible, as 
the pardoning love of Christ becomes a central, permeating, motivating reality in it.

At this point, where Christian care and nurture is being discussed, and where the demand for the meeting of human need is most acutely felt, a vitally important principle in the overall approach of this study must be discussed. In Matt 6:25-34 Jesus seems to reverse completely the accepted view of what is important to human needs, and thus to human motivation. It has been noted in this study that Maslow, for example, moves from the most basic human needs--those of human physiology (food and shelter)--to selfactualization or fulfillment. In Matt 6:33 Jesus says that as human beings grapple with the realities of God's kingdom and righteousness, a11 the other things are added to them "as a matter of course" (Philips). Jesus sees no reason to be "anxious" (vs. 31, NASB) about food and shelter. This is a "Gentile" (vs. 32, NASB) way of approaching life. As the realities of God's kingdom and righteousness are seen for what they are, these other needs seem to cease to be hierarchical or dominating to the life. Put in the perspective of God's righteousness and the realities of His kingdom, the tyranny of human need is radically reversed. All things become new. A new aeon is entered, in which persons are motivated on a completely different basis to that which has previously controlled them. In short, Jesus' view turns Abraham Maslow's on its head.

How this view of reality may be introduced into the practical life of the local church is the pragmatic question. There seems to be one overriding need at this point: that the nature of God's kingdom and righteousness be accurately represented. It seems that 
when living in God's kingdom and possessing the righteousness of God become the foci of the life of the believing community, other drives or needs take on a new perspective. A new set of values and needs is released which become the Christian's reason for action. This may be seen to be the cornerstone of a new and practical life view, where having been released from the tyranny of old needs and desires, nurturing and caring for other persons becomes a motive more dynamic than any other in an individual. Here the Christian begins from a position of fulfillment, and is thus free to interact constructively with other humans.

Until this principle of God's kingdom, i.e., the righteousness of God in the person of Christ for human persons, is grasped in practical terms, it is difficult for Christian persons to love and serve their fellow humans freely, even though they may feel under constraint to do so. When the radical principle of God's pardoning grace in Christ reaches the human soul, the natural needs and drives take on a new perspective and the saving act of God in Christ becomes the dominating motivational principle. 
CHAPTER III

THE ORGANIZATIONAL DIMENSION

Relating Organizational Aspects of

Church Life to Human Motivation

Although the local church is a fellowship organized for the worship of God, the distinctive communication of the saving truths of the Bible and the service of others, those who comprise this fellowship and engage in these activities will be largely ineffective if their own basic needs are not met. The "needs" spoken of here are not incidental. They are primary. The meeting of them is not optional, if the church is to be motivated to efficient activity, faithfully fulfilling the Divine commission. A healthy tension between an unsatisfied and a satisfied need is the most productive, motivationally speaking. 'Again, the needs spoken of here are those mentioned on the "upper" level of Maslow's hierarchy: a sense of belonging, of esteem, or as Carl Rogers states it, "positive regard," 2 and the need for self fulfillment. How these psychological needs manifest their presence in the church's fellowship, and how in the organizational life of a congregation they may be satisfied while they remain motivationally stimulating, is crucial.

This study so far has attempted to show that the good news of God's pardoning love in Jesus Christ satisfies the psychospiritual
'See pp. 6-8, 58 .
${ }^{2}$ Mischel, p. 95 . 
needs of human beings. It has been stated that this pardoning love permeates the human motivational make up in such a way as to become the dominant moving principle in the life of the Christian believer. Just as the Christian gospel constantly pervades the psychological needs of human beings, so should it be allowed to perpetually inform the corporate, organizational structures of the Christian community. All of the expressions of this corporate life, while being responsive to the gospel, must become sensitive to both the local community's needs and those of the congregation. How this can be done is the particular question of this chapter.

In other words, when it comes to the vital matter of a local church coming to an understanding of its own reason for existence, forging a unique statement of its mission, carefully constructing specific, challenging though attainable goals related to that mission, laying plans to fulfill those goals and then carrying out those plans, what are the motivational dynamics behind such a strategy? Or, more pointedly: How may such a strategy be implemented while due cognizance is given to each person's need for a sense of belonging, esteem, and personal fulfillment?. Also, how may the organizational and psychological aspects of human motivation be authentically responsive to the underlying psychospiritual principle of this study--God's pardoning love for sinners in Jesus Christ? other underlying questions may be stated as follows:

What would be the effect upon a group if its supervisor tried conscientiously to create an accepting atmosphere in which its members could work? Can you be "therapeutic" in your relations 
with those for whom you are boss, leader, administrator?

The implications behind these questions are: If there were present in a given organization an atmosphere which encouraged in its membership a sense of belonging, a consciousness of positive regard (esteem), and a concern which enhanced the quest for selfactualization, would not the members of such an organization be more likely to possess a higher degree of motivation, thus acting voluntarily in cooperation with the ideals and activities of such an organization? Conversely, however, Could such an approach be taken too far? Could the church, as an organization become so humanistic (i.e., "client centered") ${ }^{2}$ in its approach that it would create a self-oriented rather than selfless fellowship, thus defeating its purpose? Can the good news of God's pardoning love, actually meet the natural psychological motivating needs of the human being while at the same time it keeps the believer from an undesirable selfinvolvement by releasing a higher and more dominant motivational stimulus? All of these questions need to be addressed.

Meeting Congregational Needs From an Organizationa] Perspective

Every congregation possesses certain needs. Aside from those that are physical there are those "higher" needs which have been mentioned on numerous occasions in the study--the need for belonging,

Thomas Gordon, "Group Centered Leadership and Administration," quoted in: Carl Rogers, Client Centered Therapy (Boston: Houghton Miffl in Company, 1951), p. 320.

2 "Client centered" has reference to the therapeutic approach of Carl Rogers from which Thomas Gordon develops his "group centered" approach to leadership and administration. 
esteem, and self-actualization. These needs must now be explicated in the light of the local church organization, along with the needs for achievement and power. These needs will not be discussed in a systematic way, however, but will rather be viewed in the light of their overall relationship to motivation and the New Testament gospel in the setting of local church organization.

In a highly influential approach to motivation and human need from an organizational perspective, Douglas McGregor has described two theories of motivation which he calls Theory $X$ and Theory. $Y$. Theory $X$ is the traditional approach to the motivation of people in organizations: a system of rewards or threatened punishments and deprivations:- This theory is based on three assumptions:

1. That the average person inherently dislikes work and will attempt to avoid it

2. That people are irresponsible, lazy, and lack ambition, and must therefore be directed, controlled, and threatened if the objectives of the organization are to be achieved

3. That the average human being prefers to be directed, wanting to avoid responsibility.

Theory $Y$ proposes a more satisfying approach: motivating people by encouraging commitment through participation and the

${ }^{1}$ Douglas McGregor, The Human Enterprise (New York: McGrawHi11, 1960), pp. 34, 35. See a750 W. E. Beveridge, Managing the Church (Napervil1e, 111.: SCM Press, 1971), pp. 48, 49. 
satisfaction of the needs of self-actualization. 1 This theory is based on six assumptions:

1. That the expenditure of effort in work is as natural as in play

2. That if people believe in something, they will have a strong sense of responsibility toward it

3. That given opportunity, people not only accept, but desire responsibility

4. That personal commitment and responsibility to certain objectives is a function of the rewards (personal needs met) associated with their achievement

5. That human potential is widely distributed among people and is usually only partially utilized

6. That passivity or resistance to organizational needs is largely due to the approaches of the organization. Responsibility will not be learned as long as people are treated as though they were irresponsible. ${ }^{2}$

Theory $Y$ leaves it open to people to be creative, responsible, and informed about the objectives of their own and the organization's (i.e., church's) work. Members of such an organization are "experts" who co-operate in achieving objectives which they have collectively designed and for which they are corporately responsible for carrying through to reality.

${ }^{1}$ Affiliation (the sense of belonging) and a sense of possessing the esteem or positive regard of fellow workers in the "organization;" is closely tied to self-actualization. See Lyle E. Schaller, Effective Church Planning (Nashville: Abingdon, 1979), p. 159.

${ }^{2}$ McGregor, pp. 47, 48. 
Because many local congregations are accustomed to the pastor's traditionally proactive stance, and because they are largely governed by a board which is designed to plan and administer much of the church's activity, Theory $Y$ may initially appear incongruous when applied to the church. Church members have, because of the traditional form of church organization, been trained to expect a certain "elite" to take the responsibility for the organization and activity of the church. They have come to believe that they should not have, or that they are incapable, and therefore do not have any significant say in the planning organization and activity of the church. For this reason, it is a debatable (perhaps unconscious) question for many whether or not they should participate in the church's activities.

As long as such a condition prevails, the church will fail to reach the basic needs of the congregation in the area of affiliation, esteem, and self-actualization. Aside from this, the needs for achievement and power in relation to the church as an organization, will be left unfulfilled, and a condition of passivity, irresponsibility, or even resistance will prevail in much of the rank and file of the church.

The implications for motivation (whether conscious or unconscious in leadership or membership) resident in a situation which leaves members largely uninvolved in the decision-making processes of the church are threefold: 1) Oniy those who are properly initiated, who are on the "inside," are eligible to have any significant say in the affairs of the church's organizational life. This does 
not help to fulfill the average member's ultimate need for a sense of belonging or affiliation. 2) The rank and file of the church congregation is not qualified, does not know enough, or is not creative enough to participate in many of the most significant aspects of church organization. Such an attitude does little in meeting the needs of the average person for esteem or positive regard. As a result of this, such a course is demotivating, or at least motivationally nonprovocative to the congregation as a whole. 3) It takes few to fulfill the work of God in a given community, and that only those who have achieved in certain areas of Christian expertise are eligible to hold the reigns of power. This view tends to block the development of a sense of achievement in those who are excluded from the decision-making of the church, while it causes friction (which in itself, if left unattended, is highly demotivating) between those who possess power and those who feel excluded from its possession. Further, it is clear from the foregoing, that the self-actualization quotient will be lower in those who find themselves largely excluded from involvement with the decision-making of the church.'

A further implication for motivation logically grows out of a situation where McGregor's Theory $X$ may be practiced: when, largely because of poor motivational techniques employed by leadership, the average member appears to dislike or to irresponsibly avoid the work of the church, the leadership turns to the use of guilt to induce the desired activity in members of the church. Lyle Schaller speaks of "the excessive use of guilt in planning and

It should be noted that the three implications listed here are closely related to the assumptions of McGregor's Theory $X$ noted on p. 130. 
administration" as "one of the skills many churches have developed to a remarkably high level of competence." 1 He goes on to show how certain accepted forms of church administration have actually structured guilt motivations into their modes of operation. ${ }^{2}$ This use of guilt as a motivational stimulus may appear in the short term to result in the desired organizational end. In the long run, however, it tends to be counterproductive creating (if practiced extensively and over a long period of timel a low morale in the church.

The use of guilt in motivation is not aimed at meeting the needs of people, but at creating pressures in them which will drive them to action. Guilt is used to motivate not by creating an atmosphere in which human need is healthfully satisfied, thus producing intrinsically motivated persons, but by creating new needs in people on the basis of which they will be driven into action. The real intention of guilt-producing techniques is to serve the human desires of those who lead the organization and not the persons who actually make up the organization. U1timately, it also becomes evident that such a strategy does not serve the will of God either.

As the positive value of Theory $Y$ is assessed and as it is put in the light of the dynamic overtones of the New Testament gospel, we see certain factors emerging. These are important to motivation in the Christian congregation and to faithfulness to the message of Scripture. In exposing these factors, it should first be

'Schaller, p. 141 .

2Ibid., p. 151. One of the most subtle of these is articulating goals for the congregation for the coming year in vague, general, or extravagent terms without identifying who is responsible for implementing these goals. 
asked, Is it realistic for the minister to make the assumptions basic to Theory $Y$ ? Is it, for example, as natural for people to expend as much effort in work as in play? Can people actually believe in "the cause" strongly enough to feel personally responsible for its success? Does the average church member desire responsibility and possess a usable, and thus far untapped capacity for creativity? To what extent is the passivity or resistance of the membership to organizational plans or programs really due to the present motivational or organizational approach of ministerial leadership? It is true that no group of people approximates the rather idealistic implications resident in these questions, but are these implications realistically possible to the local church congregation?

It has been shown that fundamental to the motivation for a life filled with Godly activity is the realization of God's positive estimation of a person because of Christ. ${ }^{1}$ It is as God treats sinners as innocent because of Christ that they begin to act in innocence (Rom $6: 1-11$ ). As persons begin to see themselves in the light of God's reckoning in Christ, they begin to act, by the Holy Spirit, in a way consistent with it. This rudimentary means of bringing about (motivating) behavioral change may also be used on the human level, and in the leadership dimension. This is the genius of Theory $\gamma$. The theory's weakness, however, is pointed up in the above questions. What if the assumptions of Theory $Y$ simply cannot in all honesty be verified as one views a given group of people? It is at this point that the pardoning, merciful

\footnotetext{
${ }^{7}$ See pp. 55,56 .
} 
reckoning of God because of Christ comes into play. At this point the minister is under obligation, because of the gospel he believes, to view and to treat the members of the church just as God for Christ's sake views and treats him (Matt 19:27-35; Eph 4:32). As the principles of mercy and pardon are translated into a style of leadership reflective of the way God because of Christ treats humanity, the community will begin to respond to the positive regard it senses as genuinely proceeding from its leadership. Being treated as responsible Christian believers, they will tend to become responsible. Already being accustomed to responding to God on a similar basis, they will respond to church leadership in much the same way.

Aside from this, the biblical evidence is unequivocal that the first century Christian church was gripped by a deep conviction of the validity of its reason for existence. Because of this, a sense of intrinsic responsibility with regard to the objectives of their mission (Matt 28:19, 20; Acts 1:8) gripped them. They displayed, in general, an eagerness to personally "own" the responsibilities of the task. It was the gospel itself that was, through the Holy Spirit, the source of this enthusiasm. Its truth content, practical effect, joyfulness, and power, motivated the first century Christian. Through this gospel, believers truly became "brothers." They therefore possessed a powerful sense of belonging and worth within the organization.

Paui Benjamin sums this up when he says:

People do not identify closely with those institutions where they are denied psychological ownership. There is the important key: "belonging" . . . The church will never become a 
"family" unless the members are actively participating in her ministry. Those with gifts of leadership, who are denied the opportunity to exercise their abiljties will simply find other outlets for their energies.

If the essential psychospiritual needs of persons are not being met in the church, though its members may doggedly persist in a level of loyalty, no deep-seated commitment can grip them. Because that which is crucial to their motivation is not present, the underlying attitudes of the membership toward the suggestions of leadership are largely passive and even resistent. At this point leadership must not adopt the guilt strategy. It must instead intentionally turn to the practical application of the principles of the New Testament gospel. McGregor's Theory $Y$ is here consistent with the dynamic principles relevant to human motivation that are to be found at the heart of the Christian gospel. It must also be said, however, that Theory $Y$ is susceptible to becoming merely an administrative ploy (the more persuasive because of its strong responsiveness to human need), to gain the desired results from workers. The barrier to such an eventuality comes as the church applies Theory $Y$-not because it wishes to move people into a certain line of activity (as needful and legitimate as that may be), but because it is carrying out the will of its divine leadership in a way consistent with that which is fundamental to what it believes, the good news of God's pardoning love in Jesus Christ.

TPaul Benjamin, The Equipping Ministry (Cincinnatti: Standard Publishing, 1978), p. 58 . 
Goal-Setting and Planning in Relation to Local Church Motivation

Crucial to activating the church as a corporate body to constructive change is the possession of clear, need-satisfying goals.

Intentional, or goal-directed behavior is behavior directed toward goals which are anticipated as satisfying one's needs. Motivation is the desire which subsequently controls a person's energy to achieve these need-satisfying goals.

Needs have been seen so far to be a key to understanding human motivation. Needs are also a primary point of focus in the organizational arena. The goals of the group as a whole should reflect a carefully considered cross-section of the needs of the church body and the community it serves. Change in behavior may be most likely to come as the church initiates approaches which are intentionally designed to actually meet the basic needs of people. ${ }^{2}$ People cannot be expected to change in their basic needs. On the other hand, change is most likely to occur when genuine attempts are made to understand, to be responsive in organizational planning, to the real felt needs of people.

All behavior is goal directed, and the goal to which this behavior is directed is always need oriented. This behavior may not be calculated only to meet one's own needs, but may also be directed Notes), p. 204.

${ }^{1}$ Arnold Kurtz, Leadership for Church Organization (Course

${ }^{2}$ It is important at this point to restate a previous clarification. The needs spoken of here are not needs which the church can choose to deal with or not to deal with. They are not needs which might be seen as growing out of a deprivation of luxury or covetous desire. These are needs, which if left unaddressed in the church will cause normal persons to look elsewhere for their fulfillment. They are needs which must be addressed if the church is to remain a viable entity in the world. They are foundational to the normal function of the average person. 
at the meeting of the needs of others. Either way, in these terms, motivation to change rests on the desire which directs a person's (or group's) energy into behavior which is need satisfying. The more pressing the need is perceived to be, the more impelling will be the motivation behind the behavior which is initiated to meet that need. If it is to effect any positive change, the church must be aware of the nature of its own physical and psychospiritual needs as well as those of the community which it serves.

In a discussion of change on a more corporate or organizational level, the question must now be asked, How can the minister motivate his church members? Put more bluntly, the question is, How can the minister get the church as a body to do what it should do, or what he wishes it to do? The answer to this question, of course, is crucia?. In agreement with $G$. Douglass Lewis, it must be said that this per se, the minister simply cannot do. ${ }^{l}$ Every person is already motivated to meet his or her own gaols, arid these goals are oriented toward the specific needs of each person as he or she sees them. This does not, however, mean that an immovable barrier of unchristian selfishness dominates the church. The issue is rather that persons are primarily motivated to work on their own needfulfilling goals as they perceive them. A minister cannot expect to successfully move any congregation to the acceptance of goals that he is perceived as imposing on it. This seems to be especially so in an era of independence and individualization.

${ }^{1}$ G. Douglass Lewis, The Dimension of Intentionality (Harford Seminary Foundation, 1975), an unpublished manuscript. See also Hinrichs, p. 44. 
Besides this, different persons perceive and adopt a variety of different means for achieving their goals. The goals may be common ones; but the means for achieving them even within the church may be different.

If it is true that the minister cannot actually motivate the congregation because it is already motivated by varying personal perceptions of actual needs and thus goals, what then can he do? Is the human motivational structure indeed so exclusive that the needs of a given person--and thus that person's goals--cannot allow for other goals, especially those suggested by the church-or, more pointedly, God Himself in scripture? The answer to this latter question is Yes, the structure of human need is just that exclusive. It is for this reason that scripture addresses itself to the proper fulfillment of these universal needs and goals. The church must not "fly in the face" of these needs," so basic to human life (and thus human motivation). In assuming that it is "selfish" for a person to desire the fulfillment of these needs, the church can easily bypass the very means for overcoming human selfishness and moving the church as an organized body into a role that is more active and giving.

Two questions immediately emerge: What are the felt needs

IA reminder is fitting, that the needs here spoken of are specific and very basic, the need for a sense of belonging, of achievement, of esteem and positive regard, of self fulfiliment.

${ }^{2}$ This is not to deny the innate sinful self-preoccupation of humanity (see Part I, chapter I). The issue here involves the meeting of needs that according to the nature of the human situation, must be met. Therefore meeting this kind of need cannot be deemed "seTfish" per'se. 
of "my" church?. And how may these needs be translated into common goals along with specific, intentional plans directed at the meeting of those goals? It is at the point of answering these two questions that the earlier question is answered, What can the pastor do in motivating the local church?

Answering these questions on the organizational or corporate level demands that attention be focussed on clear, need responsive goals, that is, on what the group (the local church body) wishes to accomplish in terms of perceived needs. The congregation as a whole, therefore, must be given full opportunity to assess its own needs and to express them in terms of the group. As these needs are expressed, they must be put in terms of group goals. These goals must be stated specificaliy and understandably.

It may be practical for a church to begin by making one of its major goals that of simply becoming sensitive and responsive to its own specified needs and those of the community it serves. 1 Some of its goals may revolve around specific things that are needed to bring about a more concerted motivational climate. In the light of the preceding discussion the church might direct some of its energy toward one or more of the following areas of concern:

1. That the church create a climate in which people feel genuinely needed and therefore in which they have a sense of actualiy belonging

2. That each member be given full and regular opportunity to

${ }^{1} A$ helpful discussion, contributing step-by-step suggestions as to how a congregation might accomplish goal setting and planning, is presented by Alvin L. Lindgren and Norman Shawchuck, Management for Your Church (Nashville: Abingdon, 1977), pp. 89-96. 
share in the setting of attainable goals and objectives, and also share in the laying of plans to fulfill the goals and objectives

3. That all persons know in some detail what is expected of them and what authority they have to carry out their goal directed duties

4. That the members recognize their responsibilities as challenging and yet within the range of their interests and abilities

5. That some means be devised by which the progress made toward reaching the goals of the church may be clearly assessed. ${ }^{1}$

The sooner this assessment can be accurately made, the more motivating the result will be. People want rapid feedback; they need "an immediate feedback evaluating performance." ${ }^{2}$ For this reason it is important to state the goals of the church in such a way as to make evaluation possible.

Another motivating principle in connection with goal setting and planning in the church is the element of a precise terminal date for the completion of a project. Related to this is the need of every person to experience detectable satisfaction from participating in a given activity. A sense of accomplishment is needed, the knowledge that something significant has indeed been done. This becomes all the more motivationally effective when that which is learned or accomplished is associated with meeting the profound psychospiritual needs of the persons involved.

Another motivational principle is that those who take on the

${ }^{1}$ Harriet Naylor, Yolunteers Today--Finding, Training and Working with Them (New York: Association Press, 1967), pp. 64, 65. ${ }^{2}$ Schaller, p. 157. 
tasks of the church need reinforcement and support. They need the reassurance that they will not at any time be left in isolation in their task. They need to have the assurance, corroborated by action, that they can go to someone in case of need, or that someone will be with them in the execution of their duty (Matt 28:20).

Important also in motivating church members to reaching corporate goals is the matter of suiting the person taking on the task to the nature of the task. Does it seem appropriate to him as he perceives himself? Is the task frightening to him in its complexity; or is it insultingly simple? Does he, and do other people, think it is important? Does he see it as essential, or mere busy work? Is it fun to him? Is there occasion for him to use his imagination? Is there a reasonable chance of his succeeding at the task? If a reasonable number of these questions can be answered affirmatively, the motivation of the person in performing the task is likely to be higher and the overall result more satisfying.

Corporate goal setting is thus basic to motivating the local church. This is especially so if the goals are set in studied, intentional response to the foundational theological stance and felt needs of the congregation, and as the congregation is given ample opportunity to assess its beliefs and needs and set its own goals. Because church members enter the church's organizational arena already motivated, it is not possible for the pastor himself to motivate them; rather, the motivation to corporate action must come through the already existent motivations of the congregation. Plans

TNaylor, p. 67. 
for action or change must be laid corporately with this clearly in mind.

The following recommendations put in succinct, step-by-step form what is suggested in terms of setting goals and laying plans to meet these goals, with the community's and the congregations' personal needs and motivations in mind.

1. Clearly, define the local church's mission in terms of the church's theology, its needs and the needs of the community it serves. This should deal in more general terms with ultimate expectations. 1

2. State the church's purpose. This statement should deal with specifics and with actual intentions responsive to the mission statements.

3. State the church's goals. An example of this might be, "That our Church will grow by fifteen percent in 1982." These goals will correlate with the church's purpose.

4. State the church's objectives. These are to be specific, dealing with definite ways of reaching the church's goals. These objectives should be measurable and time related.

5. Delineate the church's action plans. These plans must look back at the objectives and forward to the tasks which must fulfill the objectives. They should be understandable and feasible. Those chosen to make the plans should keep in mind those who will carry out the tasks.

6. Define the tasks of members. These tasks must be

l Lindgren and Shawchuck suggest a highly practical strategy for arriving as a congregation at the clear definition of local church mission, pp. 52-59. 
specifically designed to fulfill the objectives and goals. Those who carry them out must be matched to them in terms of gifts and interest. The tasks must be spelled out and full authority granted to the workers to do what they are commissioned to do.

As the creative energies of the congrecation are unleashed, the process described above can become an activity highly motivating in itself. As organizational structures are built for evaluation and accountability, the motivation of the church body to active participation is likely to increase appreciably.

The Theological Foundation for Motivation Through Member Participation

Little discussion has so far been devoted to the theological foundations of motivational strategies in the church organization. A brief discussion of the relationship of the theological tenents of Part I of this study (especially chapter IV) to the matter of member participation is now important to the purpose of the study as a whole. The reason for centering this theological discussion on member participation is that participation is constantly implied in and indeed is integral to the whole discussion of corporate church member motivation.

This matter of member participation has its theological roots in the doctrine of "the priesthood of al.1 believers, " which in turn has its roots in the New Testament Gospel. ${ }^{2}$ The realization that all persons are alike in their direct accountability to God, was one of the most revolutionary and controversial outgrowths of the

$$
{ }^{1} \text { See p. } 64 . \quad \quad \text { See p. } 65 .
$$


rediscovery of the New Testament Gospel in the Protestant Reformation. Intimately coupled to this doctrine of equality is the principle that in Christ alone resides the rulership and administration of the church. Although church leaders are to be held in high regard and their authority respected, this leadership and authority is always to be seen as derived from Jesus Christ, the only High Priest of the church. The church is His church, and the human membership, is his Body, each part of which, regardless of "comeliness" (1 Cor 12:19$24, \mathrm{KJV})$, receives its commands to act and react from the Head, Christ.

As the church becomes aware of the pardoning love of Christ, it comes to realize that all must constantly be living by faith in the kingdom of Christ. At this fundamental level, a level which affects every other, there is no difference between the pastor and, for example, the recently baptized child who has no church "office." Christ alone is High Priest, and every other believer a priest, on equal footing, under him (1 Pet 2:9). The more this principle is internalized by the community, the more participatory and thus motivated will be the activity of the church membership. Having been drawn into the full life of the church all will begin to experience a sense of belonging, a sense of God's esteem, the church's esteem, and self esteem. Thus they will be healthfully self actualized. Finding these ongoing needs reliably fulfilled, they will become free to act in a Godly way, free to participate in selfless service. Being pardoned and having their guilt resolved, they will no longer be driven to meet this basic psychospiritual need. Instead of being compelled to fulfill natural unmet drives, they will be impelled by the love of 
Christ to participate in constructive, selfless, Godly activity.

The fundamental theological tenent of the equality of the Christian community in Christ, must be reflected by the church in the way it organizes itself. If the church denies its membership meaningful participation, on any level, ${ }^{1}$ it denies the implications of the gospel. It also shows a weakness in its theological understanding. On the other hand, as the church embraces these theological truths, successfully translating them into the practical terms of its daily life as a whole, it will find that the participation demanded by such theology is highly motivating to unselfish activity in the Christian community.

$1^{1}$ This does not mean that there are no decisions and activities that it is unnecessary and/or impractical for the church membership as a whole to participate in. The point is, however, that participation be encouraged and genuinely sought for at every appropriate point. 


\section{SUMMARY AND CONCLUSION}

\section{Summary}

This study embarked with the hypothesis that an internalized grasp of the pardoning love of God in Christ (i.e., the Christian gospel) tends to motivate Christian persons to a life of Godly activity. At the same time the human being, Christian or nonChristian, is motivated on the basis of certain natural needs: belonging, esteem, and self-actualization. The question has been, What effect, motivationally speaking, would become apparent in the local church, if the word of God's free pardon for sinners could be intentionally brought to bear upon the three natural, psychological need-drives mentioned above?

A theological foundation for the answering of this question, begins with the plight of humanity, specifically Christian humanity. Christian humanity is in a struggling, though healthy (motivationally speaking) state of psychospiritual unfulfillment, always having to call on the pardoning grace of God to fulfill a constant need. Jesus Christ has broken into human history as God's ideal man, to become through his person and work exactly that which humanity needs as it stands guilty before God's all-inclusive law. Jesus has, in his sovereign, saving act, completely provided for every person that which the awakened conscience seeks and that God's justice demands.

The means by which the human being grasps the work of Christ 
is in the Bible called faith. As the good news of what God has accomplished in Christ Jesus penetrates the receptive human mind, faith becomes active in that mind. The Holy Spirit takes the good news of Christ's accomplishments and applies this to the human mind. As this application of God's pardoning act in Christ reaches the conscience of the one who hears, it becomes the ongoing dynamic motivational principle for constructive, Godly behavior. It touches all of the motivational drives of the human being. It does not remove these drives by a single meeting of the needs on which they operate, but it constantly permeates the whole person, so that these needs are perpetually being met. This has the effect of releasing the believer from a consuming subservience to his drives, while it opens before him higher needs which are less driving and more drawing in their motivational effect.

When it comes to the church as a whole, the study has shown that the fact that the church actually finds its origin and its commission in Jesus Christ can make a crucial difference to the energy it displays in doing the work of God. Vital also to the motivation of the church is the fact that the Christian gospel demands by nature that all members in the church be seen as equal in their standing before God and must be given equal opportunity to participate in all the aspects of the church's operation. This principle goes far in supplying the need for a sense of belonging, esteem, and selfactualization among the church's membership. Further, when the membership of the church can constructively resolve some of the unheal thy ambiguity surrounding the relationship of the church to the world, some of the demotivating roadblocks to a constructive 
missional thrust into the world will be removed.

Part II of the study takes the theological principles established in Part I--specifically the motivational force of the pardoning love of Christ--and, still holding the natural motivating needs (sense of belonging, esteem, and self-actualization) in mind, relates all of this to three central aspects of local church life: the way in which the pastor approaches motivation in the local church (the ethical dimension of motivation in the church); the way the principles of motivation are applied with theological responsibility in worship, preaching, and counseling in the church; and, finally, some ways in which the principles of motivation may be applied in the goal-setting, planning, and general management of the church as an organization, while it remains faithful to its theological principles.

The ethical questions regarding motivation in the church include the personal reasons that the pastor may have for activating the church membership. Here proper motivational technique must be distinguished from manipulative strategies. Natural and supernatural motivation are different from but related to one another on the local church scene; al though natural motivation must be used, it should be constantly conditioned by an appeal to supernatural stimuli.

In the spiritual dimensions of church life the needs of the congregation are the basis on which relevant worship and preaching takes place. Church worship and preaching must address the psychospiritual needs of the church body in order for desired changes to materialize in the church. A regular, meaningful rehearsal of the 
deed of Christ and of the manner in which he has historically satisfied the most crucial needs of humankind is highly motivating to the believer, and must condition all that is done from a motivational viewpoint in the church. There is, however, a predisposition of the Christian church to appeal to the guilt of its members as a means of motivating them to proper behavior; but this method (guilt) is directly opposed to the Christian gospel. The same approach dominates the discussion of the pastor's method of facilitating change in the counseling situation. The positive regard of the counselor for the counselee is seen to be a vital force in motivating counselee change. This positive regard is directly reflective of the attitude of God to the sinner because of Christ. It is, therefore, not only motivationally sound, but theologically sound also.

A consideration of the motivational dynanics at work in the church's corporate organizational structure showed that the church must accurately reflect the Christian gospel in all of the expressions of its life and full opportunity for each church member to express himself in the organization therefore be given. As the church body perceives its basic needs and the needs of the community it serves, these must be translated into goals for the church. Plans to fulfill these goals should then be translated into the actual tasks that bring goal realization. This participating activity, reflective in principle of the Christian gospel, significantly enhances the average person's motivation to responsibility and loyal support of the work of God through the church organization. 


\section{Conclusion}

Two urgent demands emerge as this study concludes. First, it is imperative that the church come to terms with the radical nature of the Christian gospel. If the great commission is to be fulfilled, it is crucial that not only the command to "go" be obeyed, but that the community of faith possess a lucid grasp of the message which it goes into all the world to communicate. The church needs something more than it has so far manifested. It needs something that has the potency to bring about in the life of the community a selfless form of Godly activity. As one views the New Testament community, little question remains that the principle which produced that early impetus was an internalized, assimilated understanding of what God had done for human beings in His Son Jesus.

In an age of administration and managerial sophistication, it should by now be evident that the most excellent plans for organizing and moving people to action are simply not effective enough to bring about the kinds of results that the church is so eager to see. The rank and file of the church must perceive that grace lies at the heart of all God's dealings with humanity. The gospel, that which the church has all its life sincerely attempted to proclaim, is the one thing that it has had difficulty appropriating at the everyday. motivational level. The most demanding need of the church is to discover or rediscover, through the pardoning love of Chirst, what basis God really uses to bring about changed behavior in his creatures. Because of the conditioning of the common attitudes of everyday life, such a discovery of God's gracious view of humanity in Christ demands that not only in the church's pulpits must the good news be presented, 
but also in all the expressions of the church's life. Where this does not somehow occur, grace easily disappears. Because it is missing, the church's reason for responding properly to the commands of God also withers away. When this happens, compelled responses are elicited, and the result is a drift even further from grace and its ability to motivate.

The second imperative emerging from this study is that the church's local leadership come to intentionally accept, understand, and deal with the natural motivations (needs) of the congregation. The natural needs of the congregation must be respected and capitalized upon in an ethically responsible way. They must be seen as vehicles of communication and understanding, and thus, motivation. The good news of God's pardoning love must be allowed to mingle with all of the drives and motivations of the community, and through the Holy Spirit become dominant in the motivational construct of the congregation.

There is good evidence that the potentialities of the average person are far above those which are presently evident in the church.' If this is believed to be true (and it should be especially believed in the church where the operation of grace is basic to community life), then the church must be challenged to innovate and to discover new ways of organizing and directing human energy. The church can no longer afford to use the same motivational means for moving the membership to Godly activity. It has become apparent that these are largly ineffective.

${ }^{1}$ See McGregor, p. 54 . 
In the field of secular management it has been recognized that as industry in general has provided for the physiological and safety needs of its employees, the motivational emphasis has correspondingly needed to shift from these needs to the social and selfactualization needs of the employee. Secular management has acknowledged that if "under such conditions. . management continues to focus its attention on physiological needs, the mere provision of rewards is bound to be ineffective, and reliance on the threat of punishment will be inevitable."

The shift which has occurred in the industriat arena has undoubtedly had its impact on the North American church. It is yet appropriate in third world countries to approach people (either believer or non believer) on a generally "physiological" basis. The needs of such communities are still generally felt on this physiological leve1. When, however, the same basic approach is attempted in a more materially developed community, it is bound to fail.

The church must adapt itself to these facts. This is difficult, for the Bible largely addresses societies more like those of today's third world. But can the Bible speak as well to the contemporary American scene, to the "rich" as well. as the poor? The answer is a clear affirmative. The church must then take up the task of speaking to its own affluent membership and to the world in far more relevant motivational terms than those which it traditionally has used. If the church appeals to the psychospiritual needs of people where they are, it may well be more successful in reaching

I Ibid., pp. 40, 41 . 
those, both within and without the church who have formerly been considered unreachable.

The change in the needs of the society can also be seen from another point of view: just as the modern industrial employee can no longer be appealed to on the basis of physiological and safety needs because these needs have been largely met, so the average Seventh-day Adventist church member can no longer be reached, theologically speaking on the same basis that he might have been reached some years ago. Theologically and experientially speaking, much has shifted in the church. ${ }^{1}$ New attitudes and outlooks are therefore present. No longer can the minister, as effectively as before, move the church to action on the basis of reward, threat, or a simple appeal to co-operation. It is not, for example, as easy to move the average member to action by appealing to guilt producing stimuli. Theological (and/or societal) influences have removed this technique as a viable motivational strategy, by largely supplying other means for reducing guilt. Only the best, the most honorable, and the most clearly biblical motivational appeals can be effective in today's church.

As the full spectrum of motivational appeals is implemented in the church, it becomes crucial that an atmosphere of healthy service be created. Simply to move people to action on the basis of their needs for possessing a sense of belonging, esteem, and selfactualization, could well produce a seriously self-centered church.

l Little attempt to jurge or evaluate the changes in the church will be undertaken here. A change in attitude and outlook is simply noted. 
For this reason it is vitally important that any activity inspired in the church should resemble the experience of Isaiah (Isa 6:1-8). As Isaiah sees the Lord high and lifted up (vs. 1), the holiness of God becomes central (vss. 2-4) and Isaiah cries out in repentance, in view of God's splendour (vs. 5). His mouth is then touched with a coal from the altar--not to "anoint" the prophet's lips for proclamation, but to cleanse his unclean lips (vs. 5) and to remove his guilt in symbol of atonement (vs. 6). At the point of the application of pardoning grace Isaiah hears God's call to serve (vs. 8), and he immediately responds.

It is the removal of guilt that prepares and qualifies for selfless Godly action. God's pardon of sin is the act which liberates for selfless service. This must be the principle underlying all the motivational strategies of the church. 


\section{BIBL IOGRAPHY}

Theology

Anderson, Ray S., ed. Theological Foundations for Ministry. Edinburgh: $T$ \& T Clark, 1979.

Ashcraft, Morris. Rudolph Bultmann. Waco, Texas: Word Books, 1972.

Auten, Gutaf. The Faith of the Christian Church. Translated by Eric H. Wahlstrom \& G. Evrett Arden. Philadelphia: The Muhlenberg Press, 1948.

Christus Victor. Translated by A. G. Hebert. New York: The Macmillan Company, 1969.

Austgen, Robert J. Natural Motivation in the Pauline Epistles. Notre Dame, IN: University of Notre Dame Press, 1966.

Barth, Karl. Christ and Adam. Translated by T. A. Sma17. New York: Harper and Brothers Publishers, 1956. - Church Dogmatics. 4 vols. Translated by G. W. Bromiley. Vol IV, 1, 2, 3. Edinburgh: T \& T Clark, 1961.

Berkhof, Hendrikers. Christian Faith. Translated by Sierd Woudstra. Grand Rapids: William B. Eerdmans, 1973.

Berkhoff, Louis. Systematic Theology. Grand Rapids: William B. Eerdmans, 1941.

Berkhouwer, G. C. Faith and Justification. Translated by Lewis B. Smedes. Grand Rapids: William B. Eerdmans, 1954.

- Faith and Sanctification. Translated by John Vriend. Grand Rapids: William B. Eerdmans, 1977.

Bonhoeffer, Dietrich. The Cost of Discipleship. Translated by R. H. Fuiler. New York: The Macmillan Company, 1959. . Ethics. Translated by Neville Hartan Smith. New York: The Macmillan Company, 1955.

Brown, Colin, ed. The New International Dictionary of New Testament Theology. 3vols. Vol 2. Grand Rapids: Zondervan Publishing House, T967. 
Brunner, Emil. The Letter to the Romans. Philadelphia: The Westminster Press, 1959.

Buchanan, James. The Doctrire of Justification. Grand Rapids: Baker Book House.

Bultmann, Rudolf. Theology of the New Testament. 2 vols. Translated by Kendrick Grobel. Vol 2. New York: Charles Scribner's Sons, 1951.

Bunyan, John. Grace Abounding. Boston: American Tract Society, 1905.

- Justification. Swengel, Pa.: Rainer Publications, n.d. . The Pilgrim's Progress. New York: P. F. Collier and Son, 1909 .

Calvin, John. Institutes of the Christian Religion. -2 vols. Translated by John Allen. Vol. 2. Philadel phia:

Presbyterian Board of Publication and Sabbath School Work, 1921.

Cook, Cohn. "God's Grace to the Homosexual." Insight, December 7, 14, 21, 1978.

Cooke, Joseph R. Free for the Taking. Old Tappan, N.J.: Fleming H. Reve11, 1975 .

Furnish, Victor Paul. Theology and Ethics in Paul. Nashville: Abingdon Press, 1968.

Gilkey, Langdon. How the Church Can Minister to the World Without Losing Itself. New York: Harper and Row, 1964.

Green, Michael. Evangelism in the Early Church. Grand Rapids: Will iam B. Eerdmans, 1920.

Humphrey, J. Edward. Emil Brunner. Waco, TX: Word Books, 1976.

Hordern, William. Living by Grace. Philadelphia: The Westminster Press, 1975.

Jeremias, Joachim. The Parables of Jesus. Translated by S. H. Hooke. New York: Charles Scribner's Sons, 1954.

Luther, Martin. Commentary on St. Paul's Epistle to the Galatians. Greenwood, S.C.: The Attic Press, n.d.

- "The Freedom of the Christian." Three Treatises.

Philadelphia: Fortress Press, 1960. 
"An Open Letter to the German Nobility." Three Treatises. Philadelphia: Fortress Press, 1960.

Nygren, Anders. Commentary on Romans. Philadelphia: Fortress Press, 1949.

Oden, Thomas C. Radical Obedience: The Ethics of Rudolf Bultmann. Philadelphia: The Westminster Press, 1964.

Pink, Arthur W. The Holy Spirit. Grand Rapids: Baker Book House, 1970.

Segler, Franklin M. Christian Worship, It's Theology and Practice. Nashville: Broadman Press, 1967.

Stott, John R. W. Our Guilty Silence. Grand Rapids: William B. Eerdmans, 1967.

Thielicke, Helmut. The Evangelical Faith. Translated by Geoffrey W. Bromiley. Grand Rapids: WilTiam B. Eerdmans, 1974. - The Trouble with the Church. Translated by John W. Doberstein. New York! Harper \& Row, 1965.

Torrance, T. F. Theology in Reconstruction. London: S.C.M. Press, 1965.

Watson, David. I Believe in the Church. Grand Rapids: William B. Eerdmans, 1976.

White, Ellen G. The Desire of Ages. Mountain View, CA: Pacific Press, $18 \overline{98 .}$

- Messages to Young People. Washington, D.C.: Review and Herald Publising Association, 1945.

- The Acts of the Apostles. Mountain View, CA: Pacific Press Publishing Association, 1911.

- The Sanctified Life. Washington, D.C.: Review and Herald Publishing Association, 1937.

- Steps to Christ. Mountain View, CA: Pacific Press Publishing Association, 1908.

- Selected Messages. 3 vols., Washington, D.C.: Review and Herald Pubiishing Association, 1958-1980.

\section{Psychology}

Atkinson, John W. An Introduction to Motivation. Princeton, NJ:

D. Van Nostrand Company, 1964. 
Birch, David and Veroff, Joseph. Motivation: A Study of Action. Belmont, CA: Brooks/Cole Publishing Company, 1966.

DeCharms, Richard. Personal Causation. New York: Academic Press, 1968.

Heckhausen, Heinz. The Anatomy of Achievement Motivation. Translated by Kay F. Butler, Robert C. Birney, and David C. McClelland. New York: Academic Press, 1967.

Hurlock, Elizabeth. Developmental Psychology: A Life Span Approach. New. York: McGraw Hill Book Company, 1980.

Jung; John. Understanding Human Motivation. New York: Macmillan Publishing Company, 1978.

Koteskey, Ronald L. Psychology from a Christian Perspective. Nashvil1e: Abingdon Press, 1980.

Ligon, Ernest M. The Psychology of Christian Personality. Schenectady, N.Y.: Character Research Press, 1975.

Madsen, K. B. Modern Theories of Motivation. New York: John Wiley and Sons, 1974 .

Maslow, Abraham. Motivation and Personality. New York: Harper and Row Publishers, 1954.

McClelland, David C. and Atkinson, John W. The Achievement Motive. New York: Appleton-Century-Crofts, 1953. - The Achieving Society. New York: Irvington Publishers, 1976.

Mischel, Walter. Introduction to Personality. New York: Holt, Rinehart and Winston, 1971.

Rogers, Carl. Client Centered Therapy. Boston: Houghton Mifflin Company, 1951.

Shostrom, Everett L.' Man the Manipulator. Nashville: Abingdon Press, 1967.

Weiner, Bernard. Theories of Motivation. Chicago: Rand McNally College Publishing Company, 1972.

Church Ministry and Management

Anderson, Philip A. Church Meetings that Matter. Philadelphia: United Church Press, 1965. 
Benjamin, Paut. The Equipping Ministry. Cincinnati: Standard Publishing, 1978.

Beveridge, W. E. Managing the Church. Naperville, IL: S.C.M. Press, 1977 .

Christensen, James L. Don't Waste Your Time in Worship. O1d Tappan, N.J.: Fleming H. Revel1 Company, 1978.

Claypool, John R. The Preaching Event. Waco, TX: Word Books, 1980.

Clinebe11, Howard J. Mental Health Through Christian Community. Nashville: Abingdon Press, 1965.

Forsyth, P. T. Positive Preaching and the Modern Mind. New York: Eaton and Mains, n.d.

Getz, Gene A. Sharpening the Focus of the Church. Chicago: Moody Bible Institute, 1974.

Hilton, Robert M. A Comparative Analys is of the Meaning and Function of Guilt in Current Psychological Theory and Contemporary Formulations of Preaching. Ann Arbor, MI: University Microfilms International, 1965.

Horne, Chevis. "A Theology of Counseling." Pastoral Psychology. November, 1968.

Hutcheson, Richard G. Wheel Within the Wheel: Confronting the Management Crisis of the Pluralistic Church. Atlanta: John Knox Press, 1979.

Kurtz, Arnold. Leadership for Church Organization. (Unpublished Course notes).

Lewis, G. Douglass. The Dimension of Intentionality. Hartford Seminary Foundation, 1975.

Lindgren, Alvin J. and Shawchuck, Norman. Management for Your Church. Nashville: Abingdon Press, 1977.

McGavran, Donald A. and Aon, Weir C. How to Grow a Church. Glendale, CA: Regal Books, 1973.

Miller, Keith. The Becomers. Waco, TX: Word Books, 1973.

Narramore, Bruce S. "Guilt: Where Theology and Psychology Meet," Journal of Psychology and Theology. Winter, 1974. . "Guilt: Christian Motivation or Neurotic Masochism?" Journal of Psychology and Theology. Summer, 1974. 
Randolph, David Jarnes. God's Party. Nashville: Abingdon Press, 1975.

Schaller, Lyle E. Effective Church Planning. Nashville: Abingdon Press, 1979 .

Seamonds, David A. "Perfectionism: Fraught with Fruits of SelfDestruction," Christianity Today. April 10, 1981.

Worley, Robert C. Dry Bones Breathe. Chicago: The Center for the Study of Church Organizational Behavior, 1978.

General Management

D'Aprise, Roger. Struggle for Identity: The Silent Revolution Against Corporate Conformity. Homewood, IL: Dow JonesIrwin, Inc., 1972.

Dichter, Ernest. Motivating Human Behavior. New York: McGrawHi11 Book Company, 1971.

Dyer, William G. Insight to Impact: Strategies for Interpersonal and Organizational Change. Trovo, Utah: Brigham Young University Press, 1976.

Gordon, Thomas. "Group Centered Leadership and Administration," Carl Rogers, Client Centered Therapy. Boston: Houghton Miffl in Company, 1951.

Hinrichs, John R. The Motive Crisis. New York: AMACOM, 1974.

Litwin, George H., and Stringer, Robert A. Motivation and the Organizational Climate. Boston: Harvard University, 1968.

McGregor, Douglas. The Human Enterprise. New York: McGraw-Hill, 1960.

Morris, Jud. The Art of Motivating. Boston: Industrial Education Institute, 1968.

Naylor, Harriet $H$. Volunteers Today - Finding, Training, and Working with Them. Ne'w York: Association Press, 1967.

Robertson, W. J. Paul and K. B. Job Enrichment and Employee Motivation. Epping, England: Gower Press Limited, 1970.

Tannehi11, Robert E. Job Enrichment. Chicago: The Dartnel1 Corporation, 1974 .

Vroom, Victor H. and Deci, Edward L., ed. Management and Motivation. Harmondsworth, England: Penguin Books, 1970. 
Warr, Peter, ed. Personal Goals and Work Design. London: John Wiley and Sons, 1976. 
VITA

Name: Willmore Duncan Eva

Date and Place of Birth: April 19, 1944; Giwelo, Zimbabwe Undergraduate and Graduate Schools Attended:

Helderberg College, Somerset West, South Africa

Newbold College, Brackne11, England

Columbia Union College, Takoma Park, Maryland

Andrews University, Berrien Springs, Michigan

Degrees Conferred:

Bachelor of Arts, Columbia Union College, 1966

Bachelor of Divinity, Andrews University, 1969

Doctor of Ministry, Andrews University, 1981

Professional Experience

1969-1974 - Minister, Cleveland and Sandusky, Ohio

1974-1975 - Minister, Albuquerque, New Mexico

1976-1980 - Minister, Wytheville, Virginia 